\section{Scrinium Friburgense}

Veröffentlichungen des Mediävistischen Instituts der Universität Freiburg Schweiz

\section{Herausgegeben von}

Michele Bacci · Hugo Oscar Bizzarri · Elisabeth Dutton Christoph Flüeler · Eckart Conrad Lutz · Hans-Joachim Schmidt Jean-Michel Spieser · Tiziana Suarez-Nani

Band 36

\section{The Holy Portolano}

The Sacred Geography of Navigation in the Middle Ages

\section{Le Portulan sacré}

La géographie religieuse de la navigation au Moyen Âge

Fribourg Colloquium 20I3

Colloque Fribourgeois 2013

Edited by / Edité par

Michele Bacci · Martin Rohde 


\title{
On the Holy Topography of Sailors: An Introduction
}

\author{
Michele Bacci (Fribourg)
}

The title of this book, which collects essays by scholars of different origins and methodology who participated in a Symposium in Fribourg on September $2-4,2013$, hints at a peculiarly Late medieval conception of the sea as a homogeneous, though 'liminal' space, whose borders, in the sailors' experience, were thought to be dotted by an almost uninterrupted network of holy sites directly associated with the maritime dimension and the evocative power of coastal landscape. Concisely labelled as peregrinagia maritima, such holy sites did not necessarily correspond to the most famous and celebrated Christian loca sancta, even if the latter, such as Jerusalem, Rome and Santiago, often came to be associated with the sea and its perils. And indeed, in their visitors' eyes, each sea shrine stood out for one distinctive characteristic: namely their being located along the sea routes in such eminent spots as heights, promontories, bays, peninsulas, small islands and rocks, natural ports and sure anchorages (Ill. I and legend).

Such places, even regardless of their association with chapels, churches and cult-objects, were regarded by sailors as inescapable points of reference. The Medieval navigation practices actually implied an accurate visual inspection of the coastal landscape: pilots were accustomed to recognize the expanse of sea the ship was sailing through from the peculiar shape of the outline they saw on the horizon. An accurate scrutinizing was especially important, given that it made sailors aware of the dangers and risks they could run during the crossing. Unmistakable signs provided by nature itself are recorded in seafaring manuals: for example, the Bear's Rock by Palau, Sardinia, nowadays a major tourist attraction of the island, provided a very conspicuous eminence on the seacoast, which could not be missed by

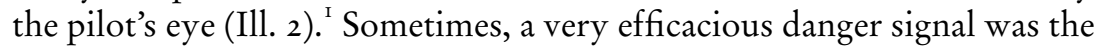
unusual form of some obstacles, such as the rose-shaped sandbank to the

I Lo compasso de navegare. Edizione del codice Hamilton 396 con commento linguistico e glossario, Ed. Debanne, Alessandra (Destini incrociati 5), Bruxel- 
south of the Asinara Island mentioned by the $\mathrm{I} 3$ th century 'Compasso de navegare'. 'The latter was just one of the several Late Medieval texts known as portolanos, which provided both invaluable practical instructions for seafarers and a great amount of geographical information, often combined with hints at the religious dimension of the sea. ${ }^{3}$

Yet nature had not always been so wise as to invest each coastal landscape with visually distinctive marks. Built structures could play an analogous role as points of orientation used by mariners in their manoeuvring, mostly when they entered harbours. By the way, the visual association of chapels and churches with the navigation practices of sailors contributed to lay emphasis on the religious significance traditionally attributed to the heights and promontories located next to bays and inlets. A skilled captain knew, for example, that, in order to enter the port of Brindisi, Apulia, safely, he needed localizing the church of Saint Andrew on the homonymous islet, in order to avoid a sandbank. ${ }^{4}$ Not unlikely, if he wanted to bring his ship into Ancona harbour, he had to 'honour' the rock marked by the small chapel of Saint Clement.' If he wished to avoid the numerous sandbanks concealed under the waves before the wharfs of Porto Pisano, he had to move through the two towers marking the entrance while looking at the hill of Montenero to the south. Had the docking be successful, the merit should have been attributed to that height rising to heaven, whose holiness was made explicit by its being inhabited by numerous hermits, who lived close to a grotto located next to a health-bearing spring. Moreover, it is probable that the connection

les 20I I, p. 94: E per meçço a cquello porto en Sardegna è en una montagna I ${ }^{a}$ petra che à nome l'Orsa, et è semblante d'orsa.

2 Lo compasso da navigare (note I), p. 95: De la bocca de Fornello ver meçço jorno ij millara è $I^{a}$ isola che se clama Rosa, e dovete entrare da garbino. Et en quello fredo è $I^{a}$ secca che semellia $I^{a}$ rosa.

3 Bellomo, Elena, Sapere nautico e geografia sacra alle radici dei portolani medievali (secoli XII-XIII), in: Dio, il mare e gli uomini (Quaderni di storia religiosa I 5), Verona 2008, pp. 2 I 5-24I; and Patrick Gautier Dalché's essay in this book.

4 Lo compasso da navigare (note I), p. 5 I: E se venite da la bocca de trammontana a Brandiçço, ben podete entrare, et guardateve da quella secca ch'è en l'isola de Sancto Andrea. Eva per meçço lo fredo enter l'isola e terra ferma. E quanno entrate en quello friedo de tramontana, quella secca dell'isola de Sancto Andrea è en lo capo dell'isola de meçço dì.

$5 \quad$ Ibid., p. 52: En capo de la starea si è $I^{o}$ scollio, et sunno scollio è $I^{a}$ chiegia che se appella Sancto Clemento. Et sopre la dicta chiegia da ponemte si à $I^{o}$ scollio sopre acqua, lontano de la dicta chiegia ij prodesi. Onorate lo scollio, per atendere a lo porto, iij prodesi. 
with the port and the religious practices of sailors caused the progressive transformation of the cave into a Marian shrine, marked by the presence of a miraculous icon, in the late i 4 th and is th century. ${ }^{6}$

The sacralisation of the coastal landscape through settlements of hermits is a frequent and very ancient phenomenon, which was well known to medieval sailors. The crews of ships sailing next to the southernmost headland of Mount Athos were the only lay people who could enjoy the sight of the steep, inaccessible cliffs dotted with the caves of solitary monks and ask for their prayers. ${ }^{7}$ Not unlikely, the mariners who were going through the coasts of Maresme, Catalonia, were probably the most frequent visitors to its many hermitages, including that of Sant Simó by Mataró, where the most ancient ex-voto in the shape of a ship preserved to our days was originally found. ${ }^{8}$ There were even impassable stacks, such as Caloiero in the neighbourhoods of Kalymnos, in the Aegean, which took its name after its only inhabitant, a holy hermit whose survival depended on the offerings left by the crews of ships in transit.. ${ }^{9}$ Such remote locations as the Strofades, two small islets in the wide expanse of sea to the south of Zakynthos, were thought to be holy because of the admirable virtues of the holy monks living there, in a thoroughly liminal space, far from the earthly dimension of ordinary life and suspended on the Biblical border between the inferior waters of the sea and the superior waters of heaven. ${ }^{10}$ Along the southern Mediterranean coast the situation was not so much different: the Spanish traveller Ibn Battuta, in the second quarter of the I 4 th century,

6 Lo compasso da navigare (note I), p. 46: La 'ntrata de Porto Piçano è cotale: quando lo fondo pare enter ij torre, fa quella via, e serrete en porto necto de tucte le secche, e per que' medesmo ver levante è Monte Nero. The history of this holy site is best illustrated by Gagliardi, Isabella, Ave Maris Stella: il santuario mariano di Montenero presso Livorno, in: Dio, il mare e gli uomini (note 3), pp. I85-2I3.

7 On late Medieval and early Modern visitors to Mount Athos cf. Reichert, Folker and Schenk, Gerrit J., Athos. Reisen zum Heiligen Berg I347-I 84 I, Stuttgart $200 \mathrm{I}$.

8 See the essay by Francesca Español in this volume.

9 Porcacchi, Tomaso, L'isole più famose del mondo, Venezia I 572, p. 34.

Io Cf. Lo compasso de navegare (note I), p. 55 ; Roberto da Sanseverino, Viaggio alla Terra Santa, Ed. Maruffi, Gioacchino, Bologna i 858, p. 49; Ulrich Brunner, Pilgerfahrt [ı 470], Ed. Röhricht, Reinhold, Die Jerusalemfahrt des Kanonikus Ulrich Brunner vom Haugstift in Würzburg, in: Zeitschrift des deutschen Palästina-Vereins 29 (1906), pp. I-50, esp. 22. The Strofades were associated to the translatio history of the body of Saint Mark in 828: cf. Urban, Lina, Processioni e feste dogali, Vicenza I998, pp. 52-53. 
witnesses for example that the Nile delta was inhabited by a great many hermitages inhabited by pious ascetics. A number of such holy men, and their venerated masjids, were concentrated on the shores of the coastal lake of al-Burubus to the east of Alexandria. The city of Damietta, so tells Ibn Battuta, was protected from pirate incursions by a long chain extended from a tower on the small island of al-Barzakh, at the mouth of the Dimyat branch, a distributary of the Nile. On this natural and political border was erected a mosque, attended by a great number of pious men, guided by a venerable shaykh, who spent all their time in prayers and in the recitation of the Koran. ${ }^{11}$

In a number of cases the sacralisation through the presence of holy men came to be enhanced or even surrogated by the public worship for a religious image deemed to be miraculous. Something like that did happen in the abovementioned Strophades islets, with the cultic success of a I 3 th century icon labelled with the evocative name of Panagia Thalassomachousa, 'The Virgin fighting with the sea'. It is not clear when this image became object of public worship, yet it is clear that its veneration was connected with the many sailors who visited the monastery on the sea route between Crete and Venice in the late Middle Ages and later. Even if a number of stories explain the Virgin's epithet as connected either to its legendary voyage from Constantinople during the Iconoclastic controversies or to the sailors' use to pour the oil of its lamp into the waves in order to calm stormy weather, it seems basically to work as a metaphoric hint at the peculiar 'liminality' of the holy site housing the image, a borderline place, a threshold between the supernatural, divine dimension and the dangerous, treacherous and menunfriendly sea space. ${ }^{\mathrm{I}}$

Another case is the Panagia Kassopitra in Corfu, whose epithet is definitely toponymic and hinting at the site of Kassiopi, a small bay used since Antiquity as an anchorage by the ships waiting for the right winds before getting into the narrow and dangerous Straits separating the island from the Albanian coast. In the I 4 th century this place, encircled by a mountain ring covered with forests, was hardly accessible by land: there laid only the ruins of a deserted ancient town, which was supposed to have been destroyed by a dragon, and the only inhabitants were two hermits who took care of

I I The Travels of Ibn Battūta, Ed. Gibb, Hamilton A. R., New Delhi ${ }^{2}$ I999, vol. I, p. 37 .

I 2 Acheimastou-Potamianou, Myrtali, entry $n^{\circ} 77$, in: Mother of God. Representations of the Virgin in Byzantine Art, exhibition catalogue (Athens, Benaki Museum, 20 October 2000-20 January 200I), Ed. Vassilaki, Maria, Athína/ Milano 2000, pp. 472-473. 
a small chapel - perhaps the remnants of the side apse of an early Christian church - housing an icon of the Virgin Mary which was said to be continuously illuminated by a lamp, even if the latter was supplied with oil only once a year. The sailors mooring thereby became used to honour it: they regularly tore off pieces of bark from a nearby fig-tree and dipped them into the lamp's oil, because it was rumoured that the liquid constituted a wonderful remedy against the dangers of both fever and stormy weather. The frequent visits of sailors caused the transformation of the structure into a shrine church, which happened to enjoy such a wide reputation among seafarers, that the famous Turkish pirate Hayreddin Barbarossa Pasha, in the mid-I6th century, felt the need to organize an expedition in order to knock it down. And indeed this did not prevent the Venetian admiral Francesco Suriano, in I 590, to build it again in elegant Western forms, regardless of its being associated with the Greek rite (Ill. 3). ${ }^{\mathrm{I3}}$

As such examples point out, mariners tended to attribute holiness to those elements of landscape that announced difficult manoeuvres or special risks during the navigation. Promontories, which ought to be doubled with skilled manoeuvring, were especially invested with such functions: because of the danger they announced, they were regularly known under an encouraging dedication to holy figures and were most often marked by religious structures. Toponymy bears witness to this process: the most important capes, located at the passage from an expanse of sea to another, are dedicated to saints, as with Capo San Vito and Capo Santa Croce in Sicily, Capo Santa Maria di Leuca in Apulia, Capo Sant'Angelo (the Italian name of Cape Maleas, in the southernmost edge of the Peloponnesus), or Akrotiri Apostolos Andreas on the north-eastern end of the Karpasia peninsula, Cyprus. In each of such places the dedication apparently predates the development of a specific cult-phenomenon and it would be tempting, yet misleading, to trace their origins even back to pre-Christian times: one could be lead to think that Apostolos Andreas, for example, simply took the place of the ancient Greek temple of Aphrodite Akrea, located in the same area, yet not

I 3 Bacci, Michele, Portolano sacro. Santuari e immagini sacre lungo le rotte di navigazione del Mediterraneo tra tardo Medioevo e prima età moderna, in: The Miraculous Image in the Late Middle Ages and Renaissance. Papers from a conference held at the Accademia di Danimarca in collaboration with the Bibliotheca Hertziana, Rome 3 I May-2 ${ }^{\text {nd }}$ June 2003 , Eds. Thunø, Erik, and Wolf, Gerhard, Roma 2004, pp. 223-248, esp. $233^{-236 .}$ 
on the same spot, were we not aware that the cult for the Christian shrine did not develop before the is th century. ${ }^{14}$

As a matter of fact, maritime shrines are a basically Late Medieval phenomenon, associated with the increase in sea exchanges during the I 4 th and I 5 th centuries. The emergence of a 'locative' form of worship on Cape Apostolos Andreas was directly associated with the practical circumstances of navigation in that area: it marked the passage from the very stormy and dangerous gulf of Antalya into the much safer Levantine sea. The presence of a spring on the site was surely not unknown to sailors, who could make a stop there to take on water. Those who doubled Cape Greco, in the south coast, knew that another source was available not far from the shore of what is now Agia Napa: and it is clearly not coincidental that a venerated shrine, located next to the cave housing the spring and associated once again with a miraculous icon of the Virgin Mary, came to be erected there probably already in the I 4 th century (Ill. 4). The interior setting of the shrine was made to suit the religious needs of its culturally composite visitors: the devotees paid homage to the spring, in the innermost of the cave, then worshipped the icon and finally, if they wished, heard the Byzantinerite mass in the naos. The Latins, on their turn, had a reserved space to the north of the Greek bema, where they were probably allowed to perform their rites and devotions. ${ }^{\text {Is }}$

Important shrines were obviously associated to the main ports. For those who survived the crossing of Antalya gulf it proved to be much more important to go on pilgrimage to Our Lady of the Cave in Famagusta, than to Apostolos Andreas or Agia Napa. According to a number of I 4 th century pilgrims, the pious visit to the 'Madonna della Cava' church was the first

I 4 On the site and its church see Enlart, Camille, Gothic Art and the Renaissance in Cyprus, transl. and ed. by Hunt, David, London 1987, pp. 309-3 I3; Jeffery, George, A Description of the Historic Monuments of Cyprus, Nicosia I 91 8, pp. 256-257; Gunnis, Rupert, Historic Cyprus. A Guide to Its Towns \& Villages, Monasteries \& Castles, Nicosia 1936, pp. I68-170; Luke, Harry, Cyprus. A Portrait and an Appreciation, London 1957, pp. I37-I4I; Kokkinoftas, Kostas, H Moví a Contested Realm. An Illustrated Guide to the Archaeology and Historical Architecture of Northern Cyprus, Kilkerran 201 2, pp. I 82-1 83.

Is Cf. Bacci, Michele, 'Mixed' Shrines in the Late Byzantine Period, in: Archaeologia Abrahamica. Studies in Archaeology and Artistic Tradition of Judaism, Christianity and Islam, Ed. Beljaev, Leonid A., Moscow 2009, pp. 433-444, esp. 443-444. 
act of all those disembarking in town. ${ }^{16}$ Voyagers did not really care about the majestic cathedral of Saint Nicholas or of any of the numerous churches within the town walls: they were determinate to go outside and to make a long walk under the Mediterranean sun to reach a small underground chapel, known in Greek as the Panagia Chrysospiliotissa and in the present-day under the Turkish name of Ulu Camii (Ill. 5). With the help of local guides I was able, some years ago, to visit this unusual place: it consists of an underground room covered with a dome, now concealed within the basement of the bell-tower, yet of considerable dimensions, as one can appreciate from the inside (Ill. 6). One has to go down thirty-three steps to reach a sort of vestibule, where devotees could leave their ex-votos and look at the officiating priests through an opening of the wall (Ill. 7). It was possible there to approach priests of both Greek and Latin rite, make an offer and ask them to perform a mass in thanksgiving for the successful crossing of the Antalya gulf. Traces of this cultic coexistence are still detectable on the east wall of

I6 James of Verona, Liber peregrinationis [1335], Ed. Monneret de Villard, Ugo, Roma 1950, p. I7: Et in die sequenti sive prima Iulii omnes mercatores et peregrini et naute et marinarii ivimus ad ecclesiam Sancte Marie de la Cava, que est extra civitatem Famagoste, quantum potest iacere arcus bis, et ibi missam devotissime celebravi et unum magnum cereum seu duplerium optulimus Virgini gloriose, que nos a tantis periculis liberavit, quia dum essemus in mari fecimus votum. Illa ecclesia est devotissima sepius visitanda et est in una caverna et descenditur ad ipsam per gradus XXXVI et est bene luminosa et ornata et picta, parve tamen quantitatis: omnes enim de mari venientes statim ad eam accedunt. Ibi sunt tres capellani qui assidue ibi stant qui cotidie celebrant propter concursum populi: nam in mari, quando cantatur de sero Salve Regina a nautis, semper unus clamando invocat auxilium primo sancte crucis de monte Calvarie, postea auxilium Beate Marie Virginis de la Cava et omnes respondent per multos annos Deus exaudiat in illa ecclesia; cfr. the almost literal German translation by Jakob von Bern, Pilgerfahrt [I 346-I 347], Ed. Röhricht, Reinhold, and Meisner, Heinrich, Deutsche Pilgerreisen nach dem heiligen Lande, Berlin I 880, pp. 45-64 (50). The church is also mentioned as visited by both Latins and Greeks by Nicola de' Martoni, Liber peregrinationis ad loca sancta [1394-I 395], Ed. Le Grand, Louis, Relation du pèlerinage à Jérusalem de Nicolas de Martoni, notaire italien (I394-I395), in: Revue de l'Orient latin 3 (I 895), pp. 566-669, esp. 63 I. Cf. Jeffery, A Description (note I4), p. 225; Gunnis, Historic Cyprus (note I4), pp. 454-455; Pavlidis, Andros

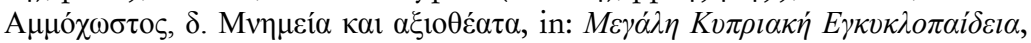
Nicosia I984, vol. II, pp. I04-106, esp. I05; Bacci, Portolano sacro (note I3),

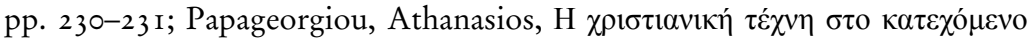

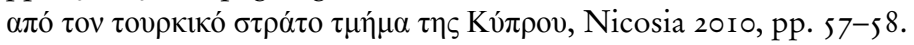


the space: a kind of Byzantine bema, with diminutive apse and prothesis, stands next to a Latin altar, included in a Flamboyant-arched wall chapel (Ill. 8). ${ }^{17}$

Admittedly, such places are often in a very bad state of preservation and sometimes even their exact location is unclear. Yet they stand out for their distinctive status of maritime shrines, suiting the different religious needs of their international and transconfessional visitors, and for another aspect, which proves to be even more intriguing. Their association with maritime sea routes contributed namely to decontextualize them from their regional dimension and to include them into a much wider topographical network, suiting the religious experience of sea voyagers. This topography is the one described in the 'Sante parole' (also known as 'Bonna parola'), a litany which was read by the ship crew before sailing and during the most critical moments of their voyage: namely, as the version included in a Florence manuscript witnesses, when the ship happened to stand offshore and off course, whereas a second version of the same text, recently discovered by Valentina Ruzzin in the State Archives of Genoa, makes clear that the crew was also accustomed to perform this same prayer before sailing. ${ }^{18}$

What is most striking in this prayer is that, even if God and his saints are quickly mentioned at its very beginning, the bulk of the text does not invoke people, yet rather a number of distinctive holy sites. To the best of my knowledge, this is the only case of a devotional exercise in which the addressees are not saints, yet the shrines where the latter were being worshipped. The invocation materialized the sailors' hope that a familiar stretch of coast with its distinctive marks appear on the horizon and enable the ship to navigate safely to its final goal. In this respect, it is no coincidence that the holy sites were listed according to a geographical sequence, starting with Alexandria of Egypt and following the coastal lines of the Levant, the Aegean, the Black Sea, the Ionian, the Adriatic, the Tyrrhenian, the Western Mediterranean and going further into the Atlantic Ocean up to the shores of England and the Netherlands. They shaped a topographic network that

I7 Further in details in Bacci, 'Mixed' Shrines (note I 5), pp. 44 I-442.

I 8 I have commented this curious text - first published by Ive, Antonio, Le 'Sante Parole' tratte da un codice fiorentino del sec. XV, in: Zeitschrift für romanische Philologie 34 (I9I0), pp. 3 I 5-330-in my Portolano sacro (note I3), pp. 242-248. The litany is to be dated between I 389 (year of the Venetian conquest of Sazan) and before 1475 (year of the Turkish conquest of Caffa). The Genoese version has been published and commented by Valentina Ruzzin, La Bonna Parolla. Il portolano sacro genovese, in: Atti della Società ligure di storia patria, n.s. 53/2 (20I3), pp. 2I-59. See also her article in this volume. 
was unlike any other in that it did not correspond to one 'Holy Land', to a region deemed to be holy because of its memorial connection with fundamental persons or events of Christian history, yet to the natural, earthly borders of the threatening and indomitable sea world, where only sailors dared venture. Far from being static and homogeneous, this geographic space was largely determined by the dynamic connections within the wide network of ports and anchorages where ships used to call at. It corresponds largely to the Mediterranean, but the very fact that it includes a number of sites along the Atlantic route will prevent us from interpreting it as a specific Mediterranean phenomenon.

As we have pointed out, sailors adopted a global perspective and recommended themselves to all of the sea shrines known to them either when they had to begin a new voyage or when they did no longer know where they were. This practice can be interpreted as just the final outcome of their habit to invoke sites, instead of saints, when passing through especially dangerous sea traits. In some special situations sailors agreed that appealing to the sitebound power of the nearest shrine was more efficacious than supplicating any of the specific holy patrons of mariners (such as St. Nicholas of Myra, St. Erasmus of Formia, St. Phokas of Sinope or the Virgin Mary): physical, rather than spiritual, proximity proved then to be especially helpful. An interesting example of this attitude is encountered in the travelogue of Duke Alexander of Palatinate (I 495), where the crossing of the strait of Butrint, was described in these terms:

On Monday, July 2oth, we sailed during day and night with a very weak wind. As our captain realized that we could not benefit from any useful wind, he strongly encouraged all pilgrims, sailors and others to supplicate Our Lady of Kassiopi to provide us with wind. Kassiopi is a church, located about is miles from Corfu, where our Lady works miracles. As soon as this happened, a moderately strong wind came to us and lasted from Midday to Midnight. ${ }^{\text {I9 }}$

Sailors pronounced their prayers to the Kassopitra Virgin while looking at her shrine on the Corfiote coast just before entering the dangerous strait, dotted with rocks and overrun by Albanian pirates. In this way, the established a direct visual relation to the miraculous icon which, by virtue of its physical proximity, assisted ships during their delicate manoeuvres. It was this essentially visual relationship that crews aimed at re-establishing by

I9 Karbach, Jürgen, Die Reise Herzog Alexanders von Pfalz-Zweibrücken und Graf Johann Ludwigs von Nassau-Saarbrücken ins Heilige Land, I 495-I496, nach dem Bericht des Johann Meisenheimer, in: Zeitschrift für die Geschichte der Saargegend 45 (I997), pp. I I-I I 8, esp. 54. 
performing the 'Sante Parole' when their boats happened to navigate off course.

In this book we have made efforts to reconstruct the odd, yet extremely fascinating holy geography of the sea and to understand the ways in which it was perceived and experienced. Patrick Gautier Dalché's and Michel Balard's essays are conceived as preliminary studies introducing readers to the religious dimension of maritime cartography and navigation practice. Then the index of this book corresponds largely to a list of the major anchorages mentioned in the 'Sante Parole', including the Near Eastern ports of Alexandria and Jaffa (David Jacoby), Beirut (Nada Hélou), Candia (Maria Georgopoulou), Patmos (Chrysa Maltezou), the Dalmatian coast (Joško Belamarić), the Maltese Archipel (Mario Buhagiar), Naples (Vinni Lucherini), Genoa (Valeria Polonio and Valentina Ruzzin), Catalonia (Francesca Español), and Valencia (Amadeo Serra Desfilís). The Atlantic coasts are basically represented by Adeline Rucquoi's essay, which unveils the maritime side of pilgrimage to Santiago de Compostela, usually neglected by scholarship.

This collection of essays should therefore be perceived as an invitation to embark on a very peculiar voyage in book-form, which aims at opening new interdisciplinary perspectives on an important aspect of late medieval devotion, on the cross-cultural interactions mediated by the sea and on the specific role played by holy sites and locative forms of worship compared with other manifestations of 'Christian materiality'. Last but not least, it provides a maritime clue to our understanding of the complex dynamics underlying the human tendency to invest material objects and portions of landscape with supernatural, meta-human, and divine qualities. 
Illustrations 


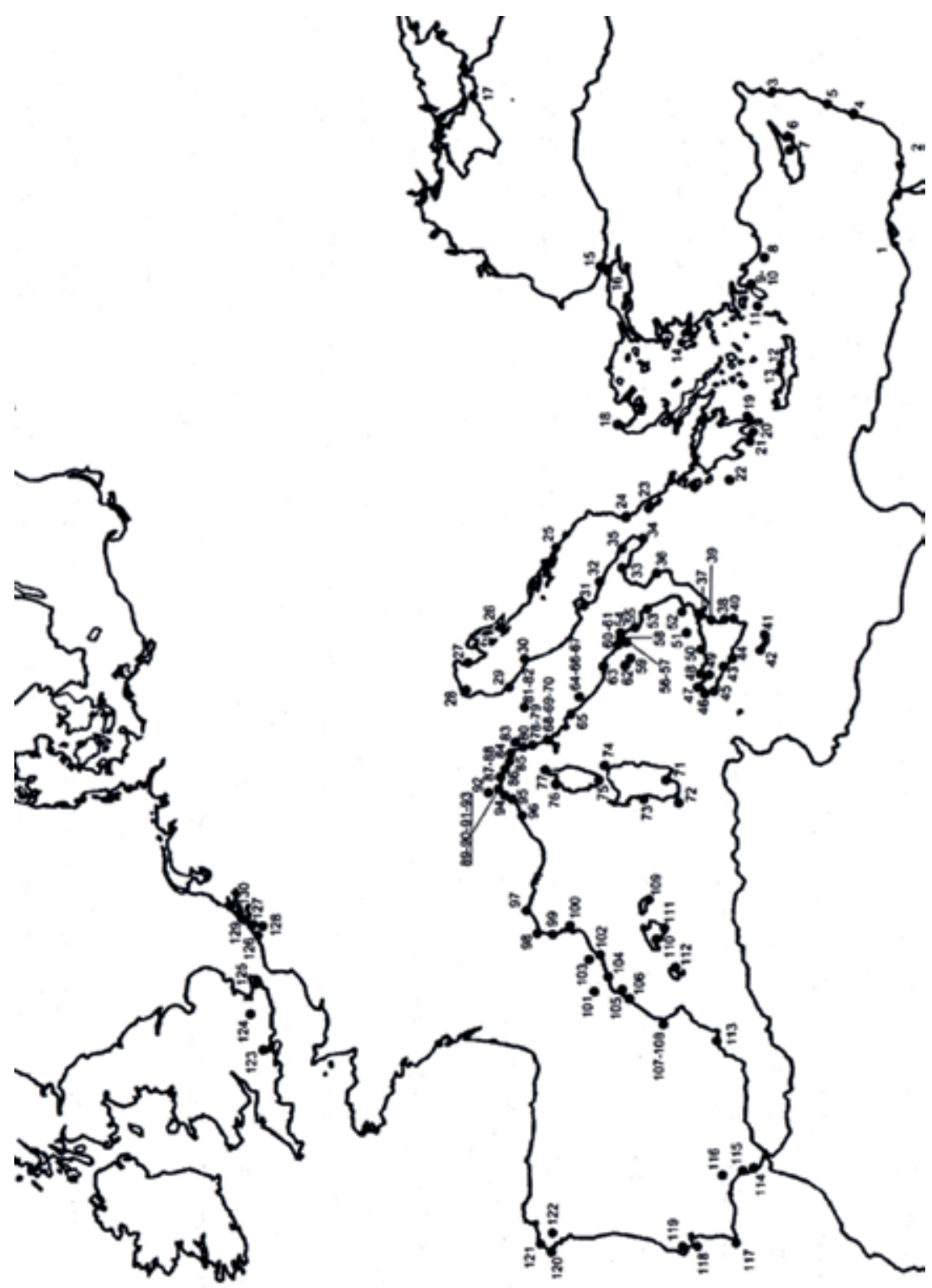

Ill. I - The holy topography of navigation according to the Sante Parole (Firenze, Biblioteca Nazionale Centrale, Ms. Magliab., VII [8], I I45, ff. $25 \mathrm{r}-27 \mathrm{v})$. 
List of the holy sites mentioned in the 'Sante Parole' (see Illustration I)

I. Alexandria, Hagios Savvas

2. Mount Sinai, Monastery of Saint Catherine

3. Lattakieh, Church of the Holy Saviour

4. Mount Carmel, Hagia Marina

5. Beirut, Saint George

6. Famagusta, Our Lady of the Cave

7. Stavrovouni Monastery, Cyprus

8. Kastellorizo, church of Hagios Georgios

9. Rhodes, churches of Saint John of Kollakion and Saint Anthony of Mandraki

Io. Rhodes, Our Lady of Philerimos

I I. Chalki, Saint Nicholas

I 2. Candia, Hagia Paraskeve/Santa Vereconda

I3. Candia, Panagia of Fraskia

I4. Chios, Saint Isidore

I 5. Ortaköy, Saint Phokas

I6. Constantinople, Hagia Sophia

I7. Caffa (Feodosija), Saint Francis

I 8. Thessaloniki, Hagios Dimitrios

I9. Cape Maleas, Hermitage of the Archangel Michael

20. Korone, Saint Francis

2I. Modone, Saint Leo

22. Strophades islands, Saint Mary

23. Kassiopi (Corfu), Our Lady the Kassopitra

24. Sazan island (Valona), Our Lady of Sazan

25. Dubrovnik, Sveti Vlaho

26. Zadar, church of Saint Gregory (probably mistake for Saint Chrysogonus)

27. Poreč, Saint Julian

28. Venice, Saint Mark

29. Rimini, Saint Julian

30. Ancona, Saint Cyriacus

3 I. Mount Gargano, church and cave of the Archangel Michael

32. Bari, Saint Nicholas

33. Taranto, Saint Cataldus

34. Santa Maria di Leuca, shrine of the Virgin Mary

35. Brindisi, Santa Maria del Casale 
36. Crotone (neighbourhoods), Our Lady of Capo Colonna

37. Messina, Santa Maria della Scala

38. Brucoli, Madonna Adonia

39. Catania, Sant'Agata

40. Syracuse, Santa Lucia

4I. Malta, church of Saint Catherine

42. Gozo, church of Saint John

43. Agrigento, church of Saint Francis

44. Licata, church of Saint Christopher

45. Marsala, Santa Maria della Grotta

46. Trapani, shrine of the Annunziata

47. San Vito Lo Capo, church of Saint Vitus

48. Palermo, church of Saint Lucy

49. Monreale Cathedral

50. Cefalù Cathedral

5. Lipari Cathedral

52. Tropea, church of Santa Maria all'Isola

53. Porto San Nicola

54. Salerno, San Matteo

55. Punta Licosa

56. Amalfi Cathedral

57. Positano, Santa Maria Assunta

58. Passiano by Cava dei Tirreni

59. Capri, San Costanzo

6o. Naples, Santa Chiara

6I. Naples, Madonna di Piedigrotta

62. Lacco Ameno, Santa Restituta

63. Gaeta, Santissima Annunziata and Trinity church

64. Rome, the seven hills

65. Civitavecchia, Santa Ferma/Firmiana

66. Rome, Santo Stefano Rotondo

67. Rome, Saint Peter's and San Paolo fuori le Mura

68. Piombino, Madonna del Belvedere

69. Piombino, Sant'Antimo

70. Baratti, San Cerbone

71. Cagliari, Madonna di Bonaria

72. Isola di San Pietro, Sardinia

73. Oristano, Cape San Marco

74. Island of La Maddalena, Sardinia

75. Bonifacio, Saint-Érasme 
76. Calvi, Saint-François

77. Rogliano (neighbourhoods), Santa Maria della Cappella at Cape Corso

78. Livorno, Madonna di Montenero

79. Livorno, Santa Giulia

80. Pisa (neighbourhoods, San Piero a Grado)

8I. Pisa, saint Ranieri of Pisa (worshipped in the town cathedral)

82. Florence, Santissima Annunziata

83. Florence, Baptistery of San Giovanni

84. Lucca, San Martino, Volto Santo

85. Bocca di Magra, Monastery of Corvo

86. Isola del Tino, Portovenere

87. Punta del Mesco, Hermitage of Saint Anthony

88. Portofino, San Nicolò di Capodimonte

89. Abbey of San Fruttuoso of Capodimonte

90. Genua, Abbey of San Giuliano at Boccadasse

9I. Cornigliano Ligure, shrine of the Madonna Incoronata

92. Genua (neighbourhoods), Santa Maria del Garbo

93. Voltri, Sant'Ambrogio

94. Savona Cathedral

95. Capo di Noli

96. Cannes (neighbourhoods), Île Ste-Marguerite

97. Villeneuve-lès-Maguelone, St.-Pierre

98. Narbonne, Saint-Paul

99. Cap Leucate, by Perpignan

I00. Collioure

IоI. Montblanc, Virgen de la Serra

I02. Barcelona Cathedral

I03. Montserrat, shrine of Our Lady of Montserrat

I04. Tarragona Cathedral

I05. Tortosa, Santa María de la Rápida

I06. Peñiscola, Santa María

I07. Valencia, Santa María del Puig

I08. Valencia, Santa Maria del Mar

ı09. Maó (Minorca), Santa María

i io. Palma de Mallorca, La Seu

I I I. Porto Pí, Saint Nicholas

I I2. Ibiza Cathedral

I I 3. Cartagena, Santo Domingo

I 4. Cadiz, Catedral Vieja (Santa Cruz) 
I I 5. Puerto de Santa María

i $6 . \quad$ Sevilla Cathedral

I I7. Cape São Vicente

i 8 . Cape Espichel, Nossa Senhora da Pedra Mua

I 19. Lisbon, São Domingos

I20. Finisterre, Santa María de Fisterra

I 2 I. Muxía, Nuestra Señora de la Blanca

I22. Santiago de Compostela Cathedral

I23. Southampton

I24. London, Saint Paul's

I 25. Canterbury

I26. Sinte-Katherine by Ostende

I27. Sluis

I 28. Bruges, Heilig-Bloed-Basiliek

I 29. Middelburg

I30. Goes (Zuid-Beveland) 


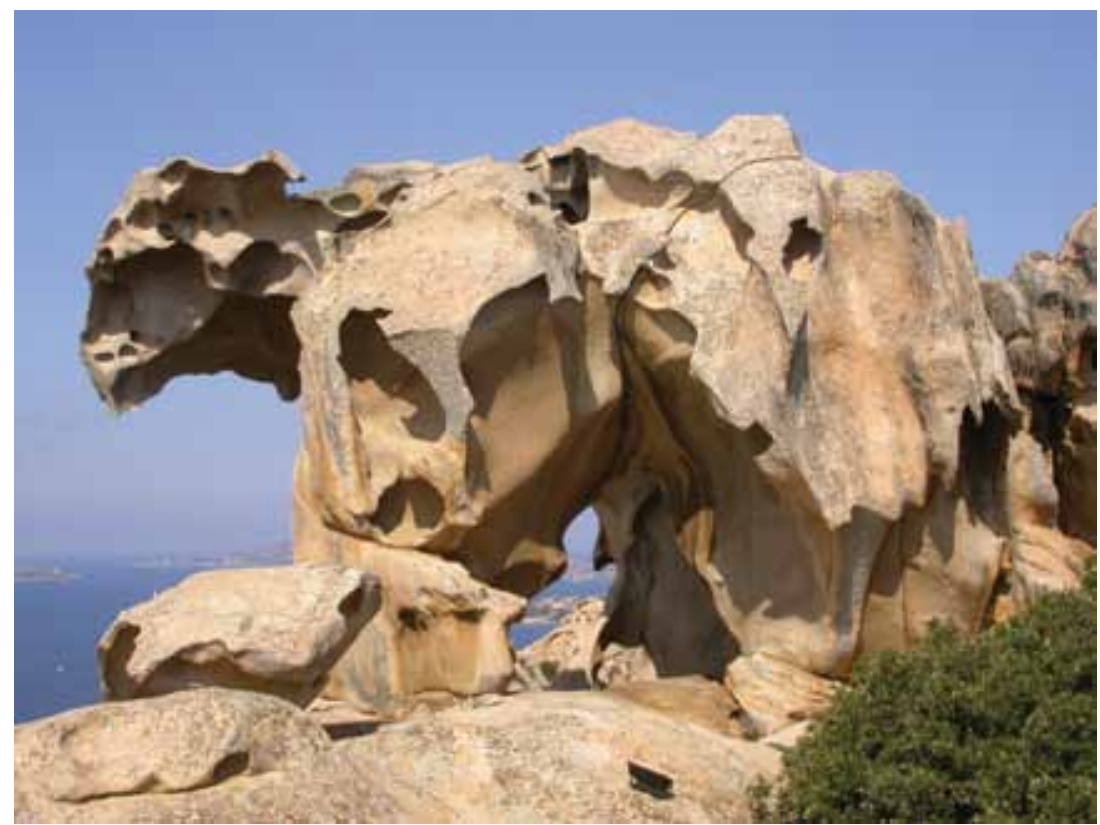

Ill. 2 - Palau, Sardinia, the Bear's Rock (Photo: after http://it.wikipedia.org/ wiki/File:Capo_dorso.JPG). 


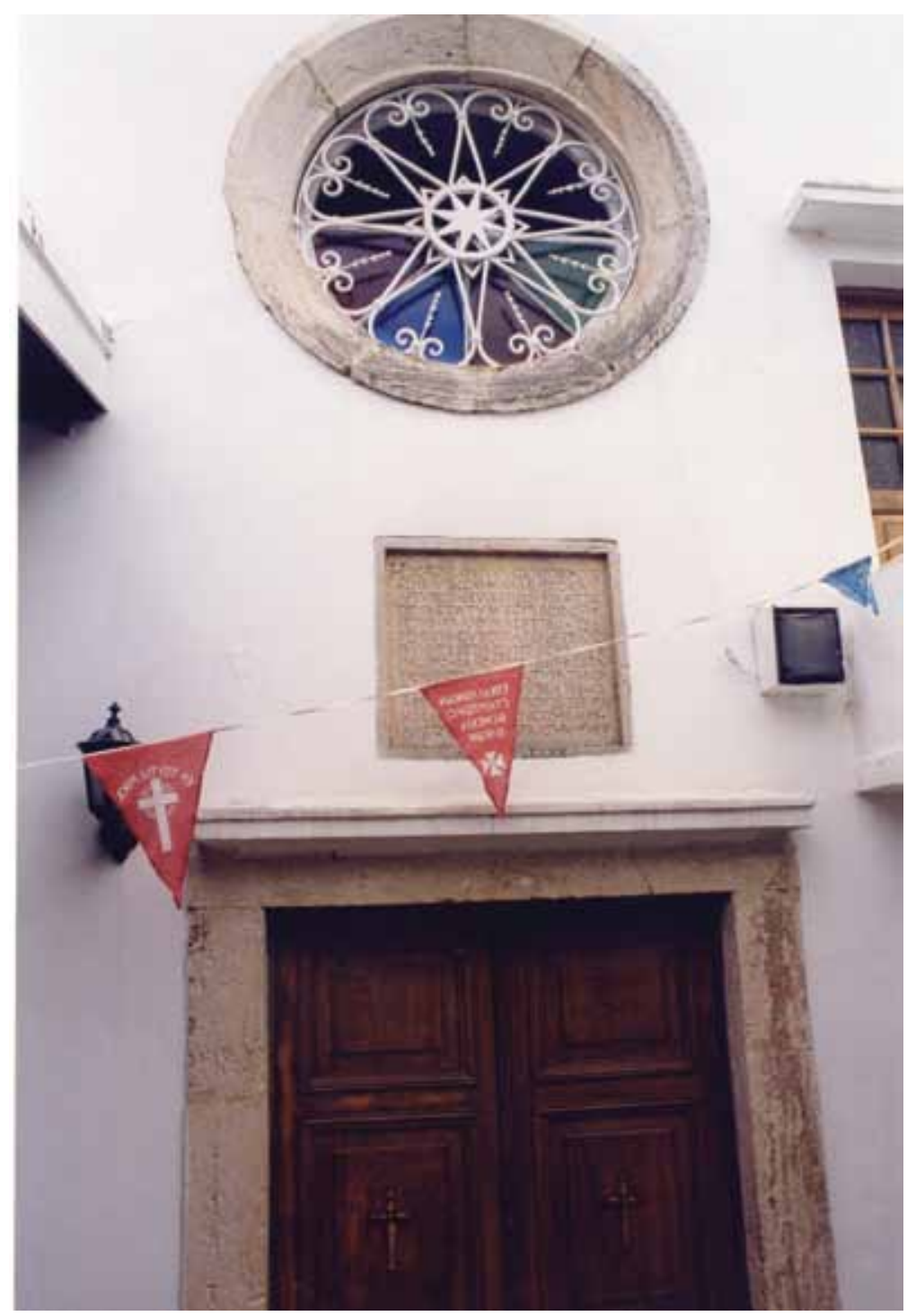

Ill. 3 - Kassiopi, Corfu, Façade of the Kassopitra Church with the Latin inscription of Admiral Francesco Suriano (Photo: Spiridione Curuni, Rome). 


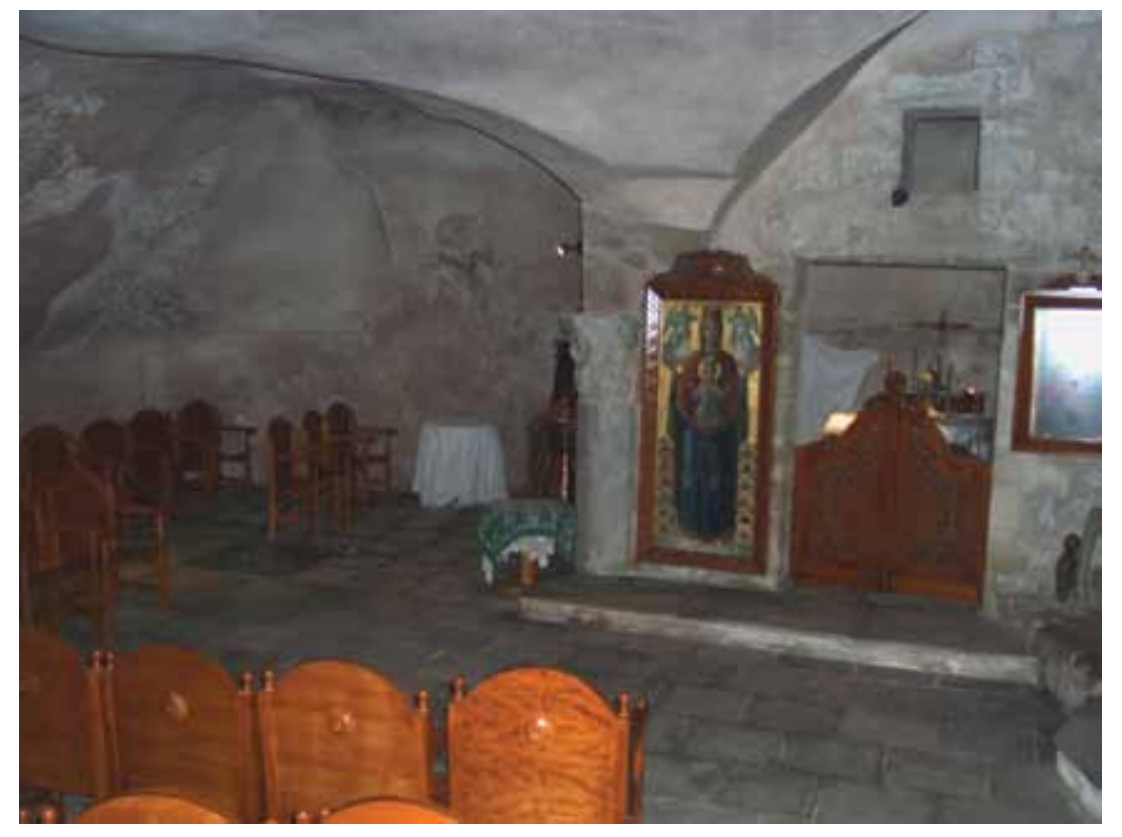

Ill. 4 - Agia Napa, Cyprus, Interior of the Holy Cave (Photo: author). 


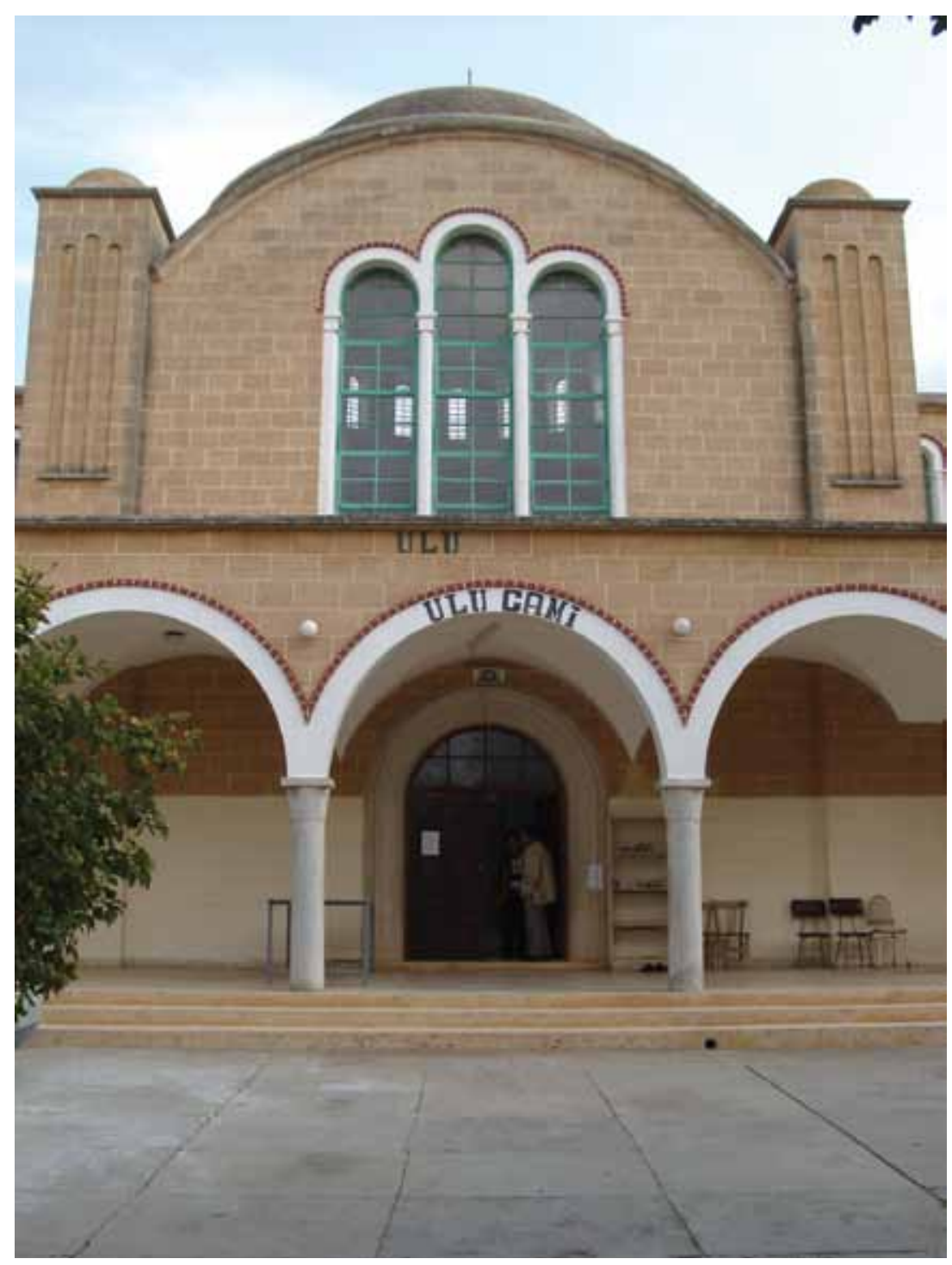

Ill. 5 - Famagusta, Cyprus, the former bell tower of Panagia Chrysospiliotissa church, presently known as Ulu Camii (Photo: author). 


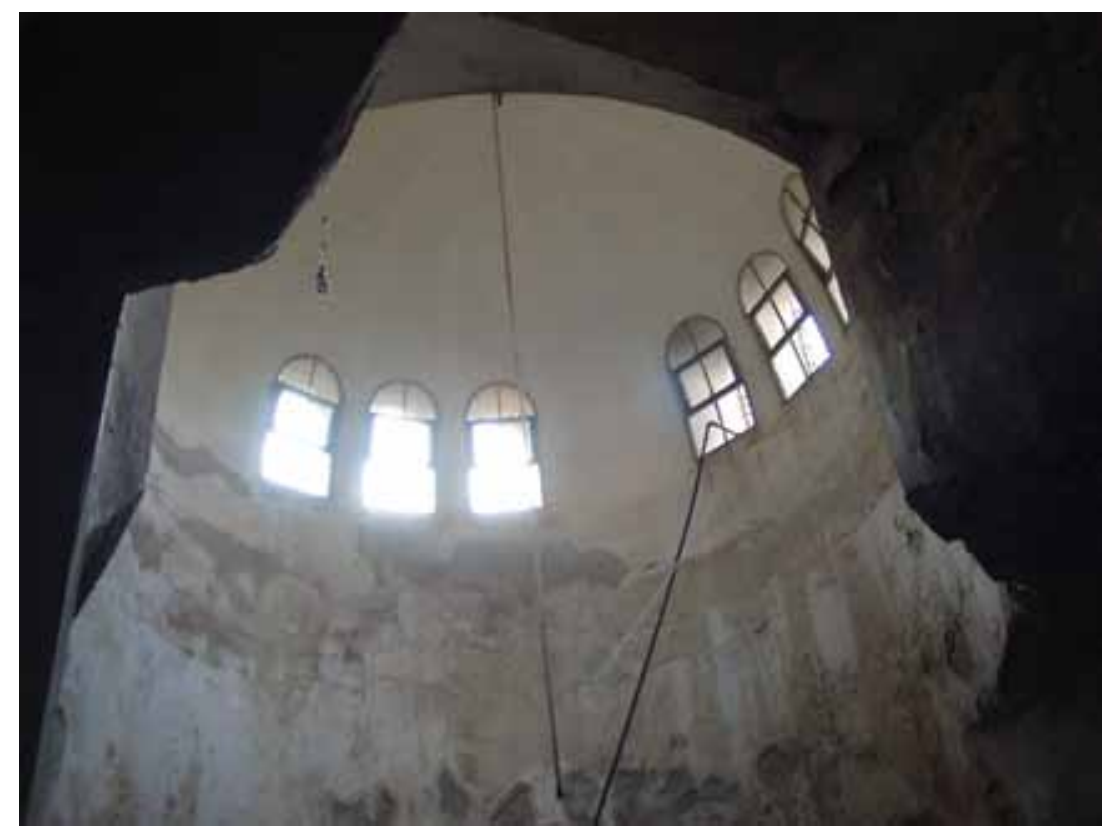

Ill. 6 - Famagusta, Cyprus, Panagia Chrysospiliotissa church, view of the dome (Photo: author). 


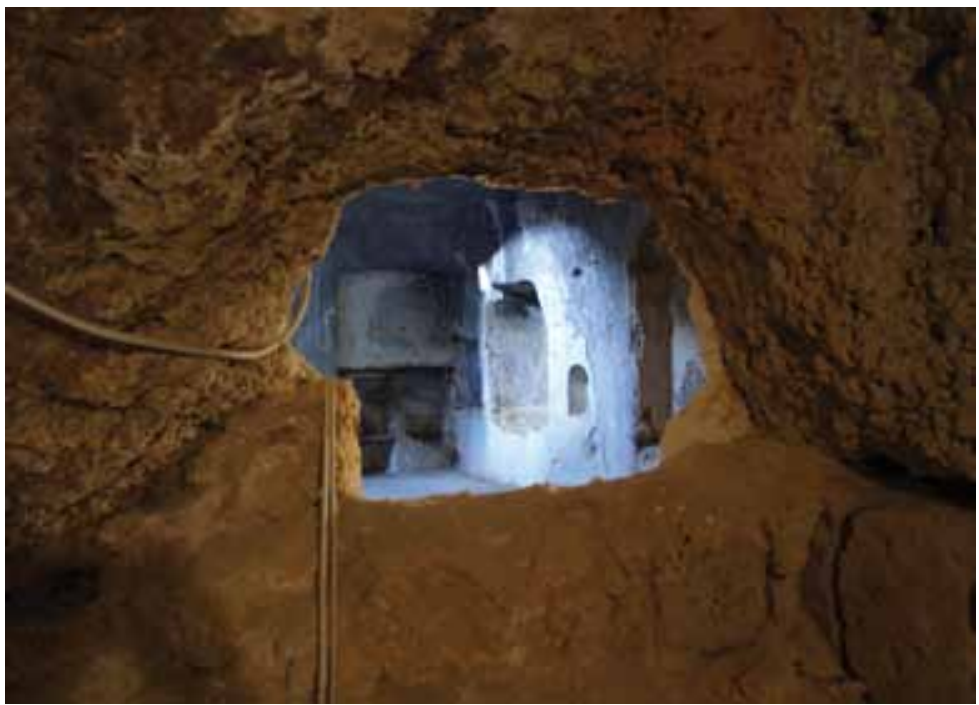

Ill. 7 - Famagusta, Cyprus, Panagia Chrysospiliotissa church, view from the Narthex (Photo: author).

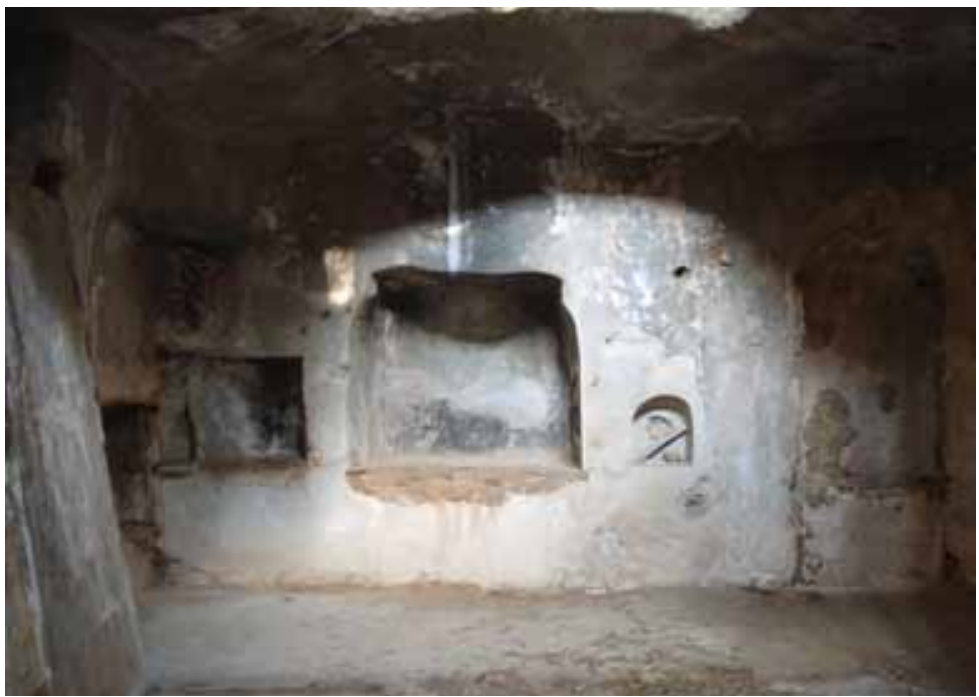

Ill. 8 - Famagusta, Cyprus, Panagia Chrysospiliotissa church, view of the east wall with Byzantine-rite and Latin-rite altars (photo: author). 


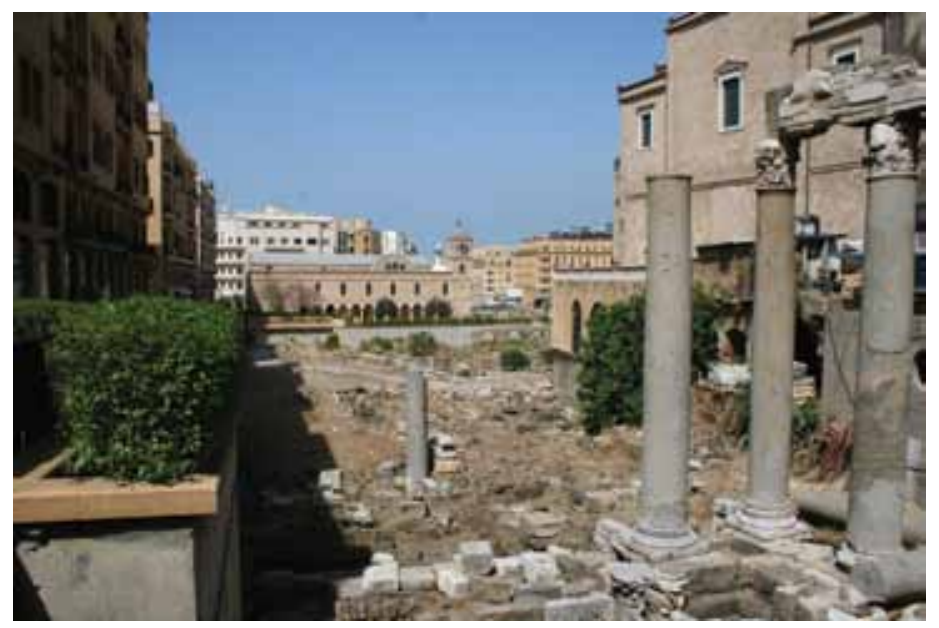

Ill. 9- Les excavations de Beyrouth avec, au fond, l'église de Saint-Georges.

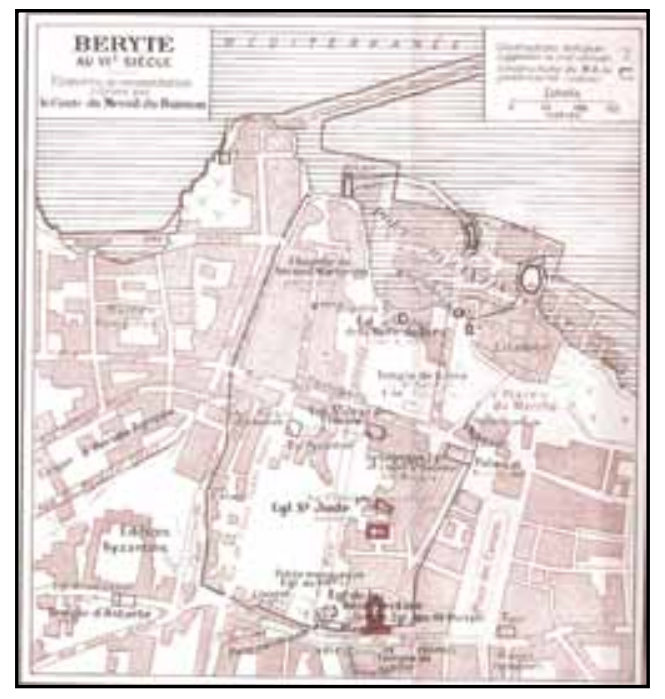

Ill. io - Plan d'après le Comte du Mesnil du Buisson. Emplacement des églises de Beyrouth au VI' siècle. 


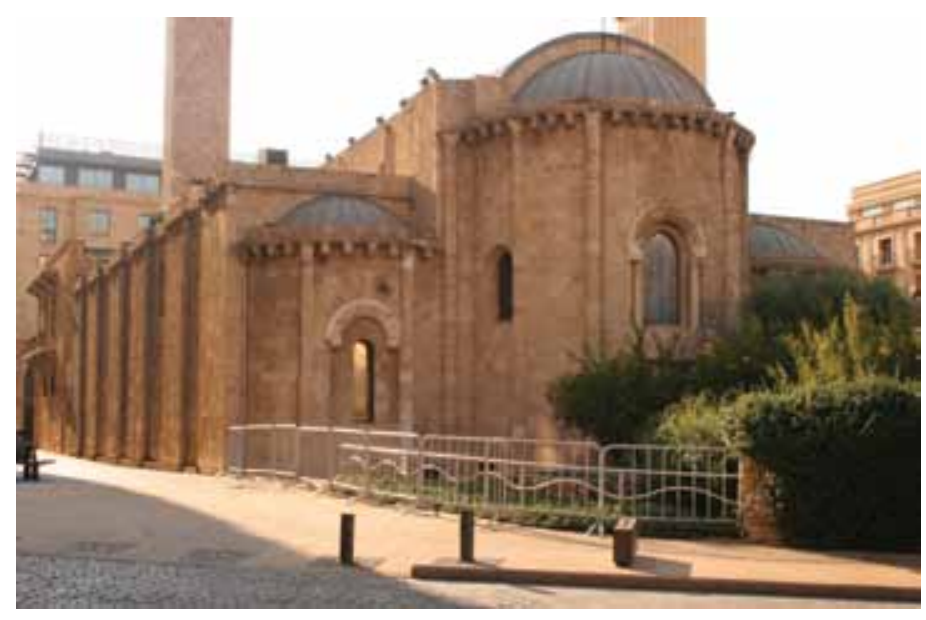

Ill. I I - Beyrouth, Église de Saint-Jean ( I I I 3), vue du côté Est.

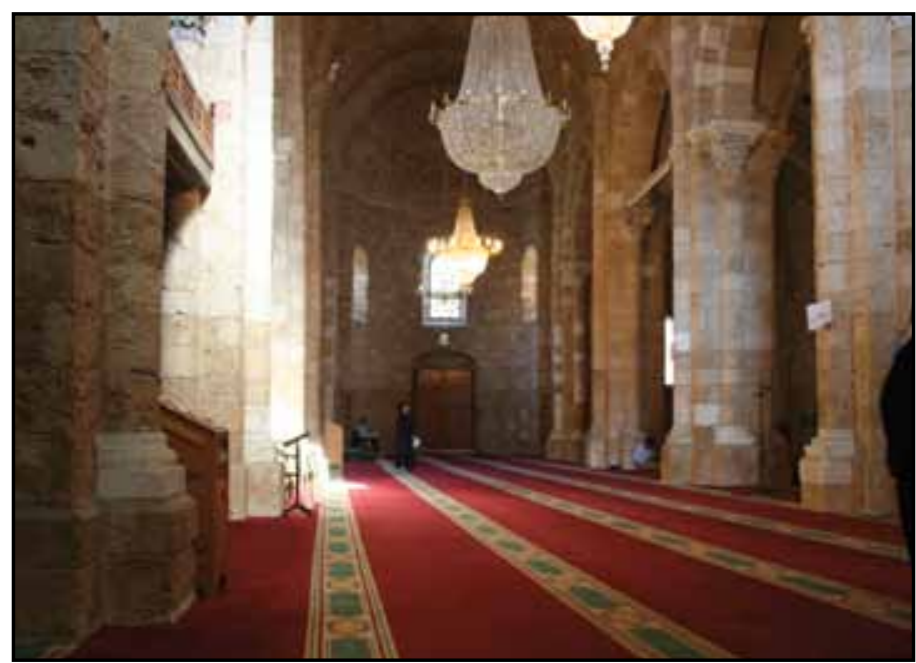

Ill. I 2 - Beyrouth, Église de Saint-Jean ( 1 I I 3), Intérieur. 


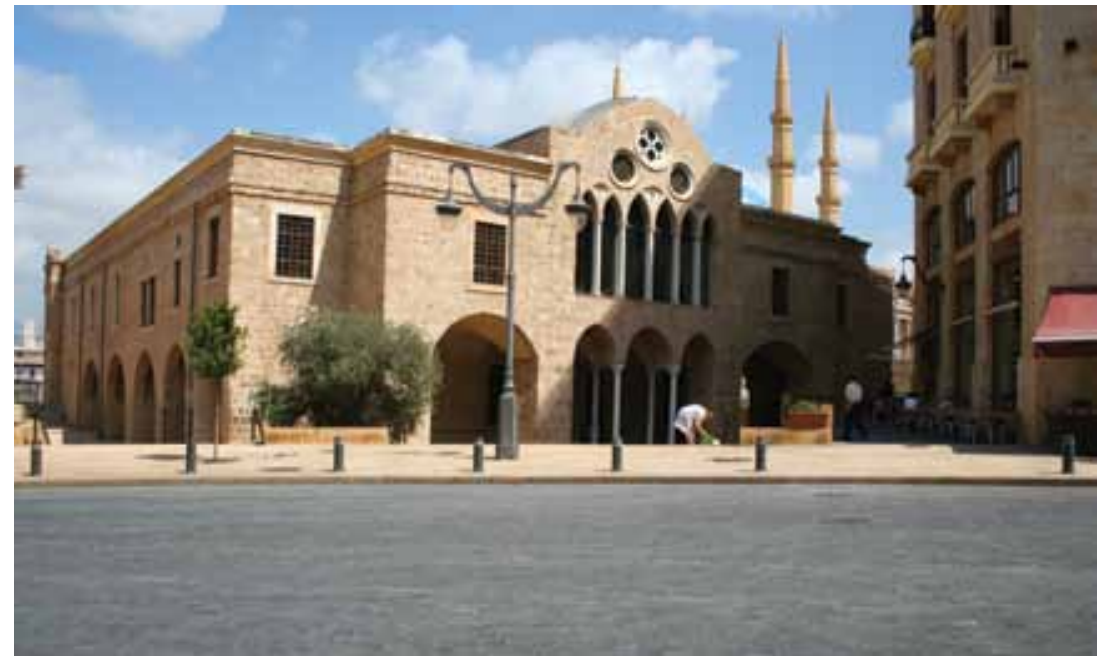

Ill. I 3 - Beyrouth, Église Saint-Georges-des-Orthodoxes (2010), Façade Ouest.

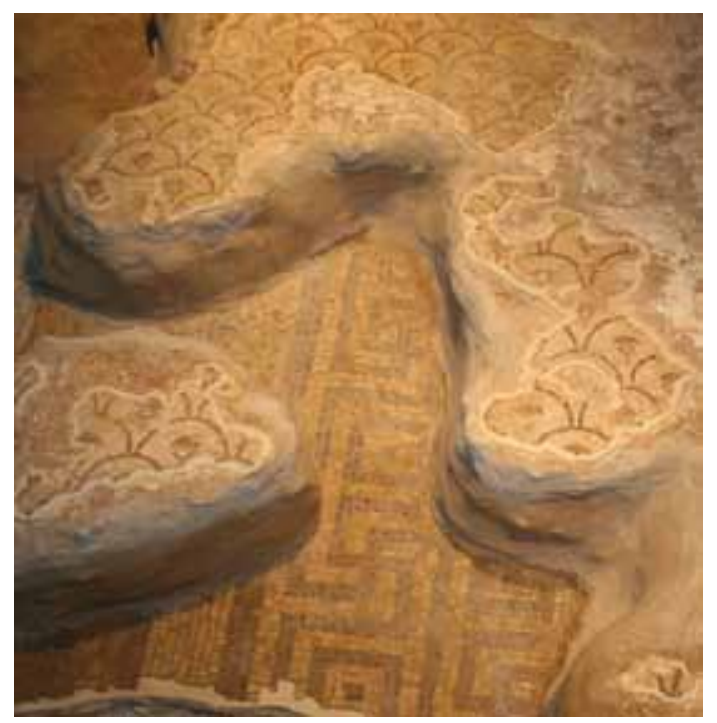

Ill. I4 - Beyrouth, Crypte de l'église Saint-Georges-des-Orthodoxes, deux couches de mosaïques ( $\mathrm{V}^{\mathrm{e}}-\mathrm{VI}^{\mathrm{e}}$ siècles). 


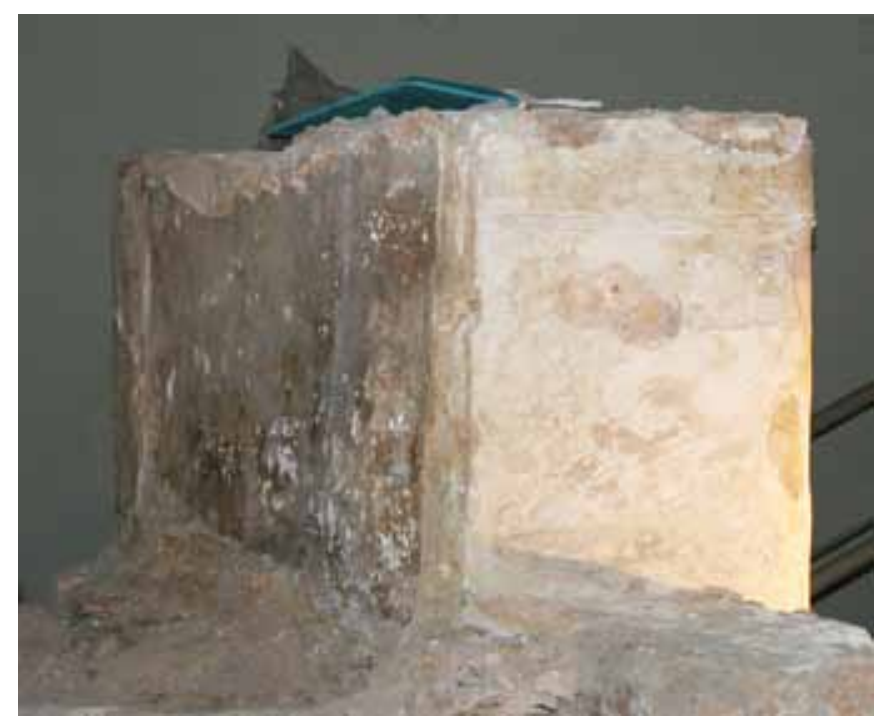

Ill. I s - Beyrouth, Crypte de l'église Saint-Georges-des-Orthodoxes, vestige de l'église médiévale, Pilier. 


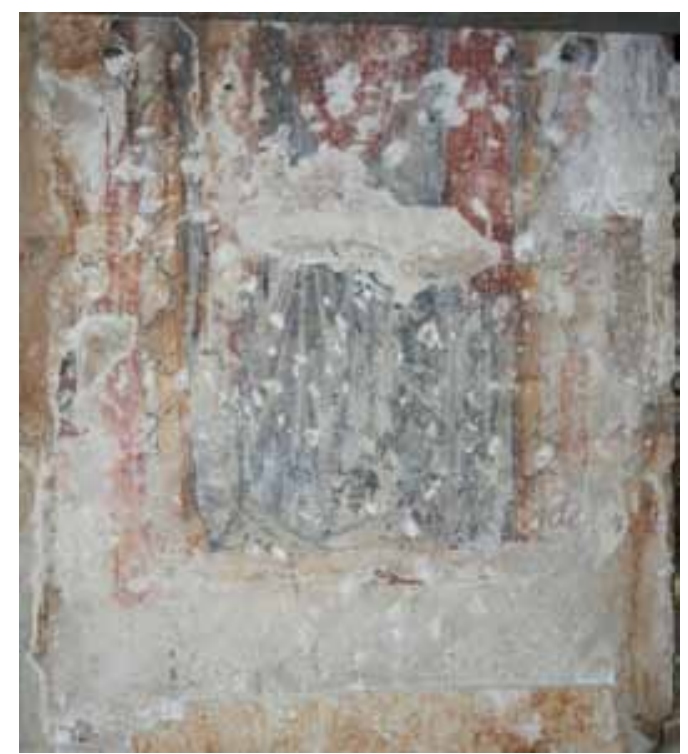

Ill. I6 - Beyrouth, Crypte de l'église Saint-Georges-des-Orthodoxes, fresque sur un pilier, figure debout.

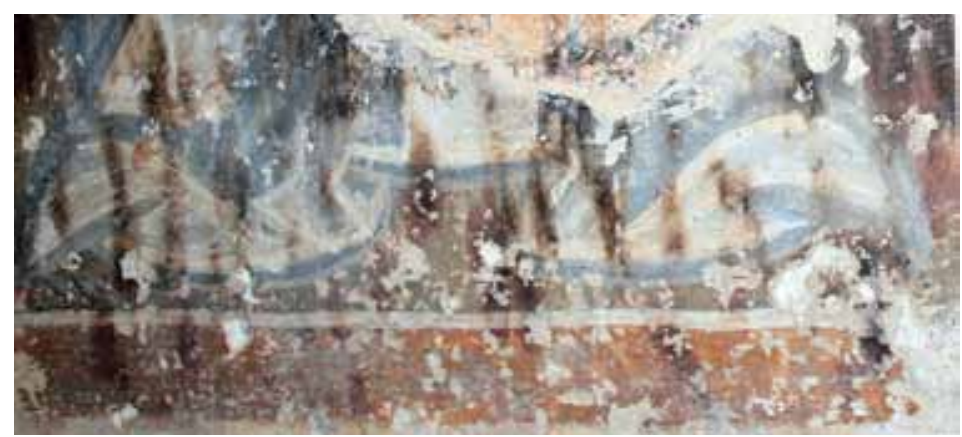

Ill. I7 - Beyrouth, Crypte de l'église Saint-Georges-des-Orthodoxes, fresque sur un pilier, figure debout ou assise, pan de vêtement. 


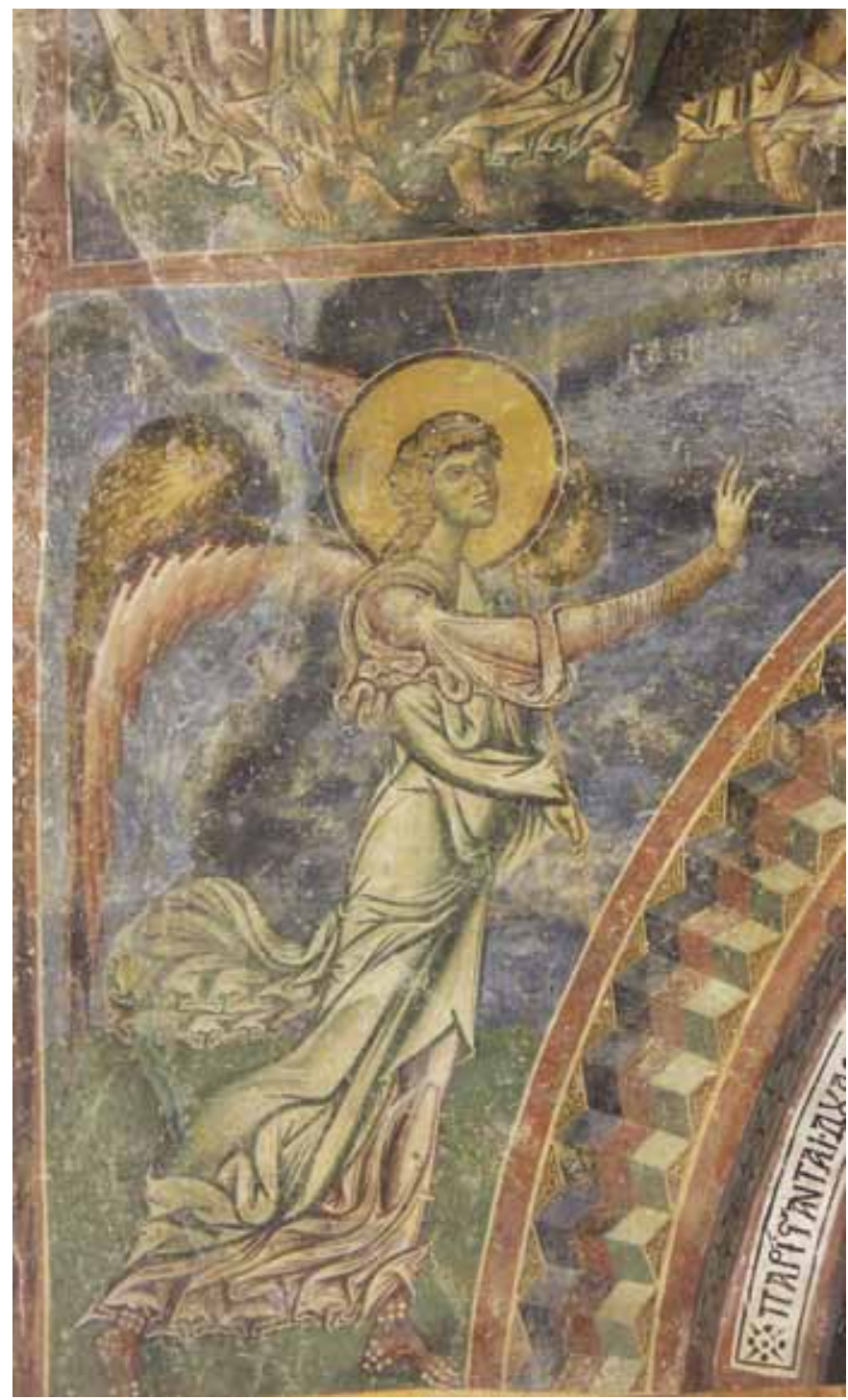

Ill. I 8 - Kourbinovo, Macédoine, Église Saint-George, fragment de l'Annonciation, l’Archange Gabriel, fresque (I I9I). 


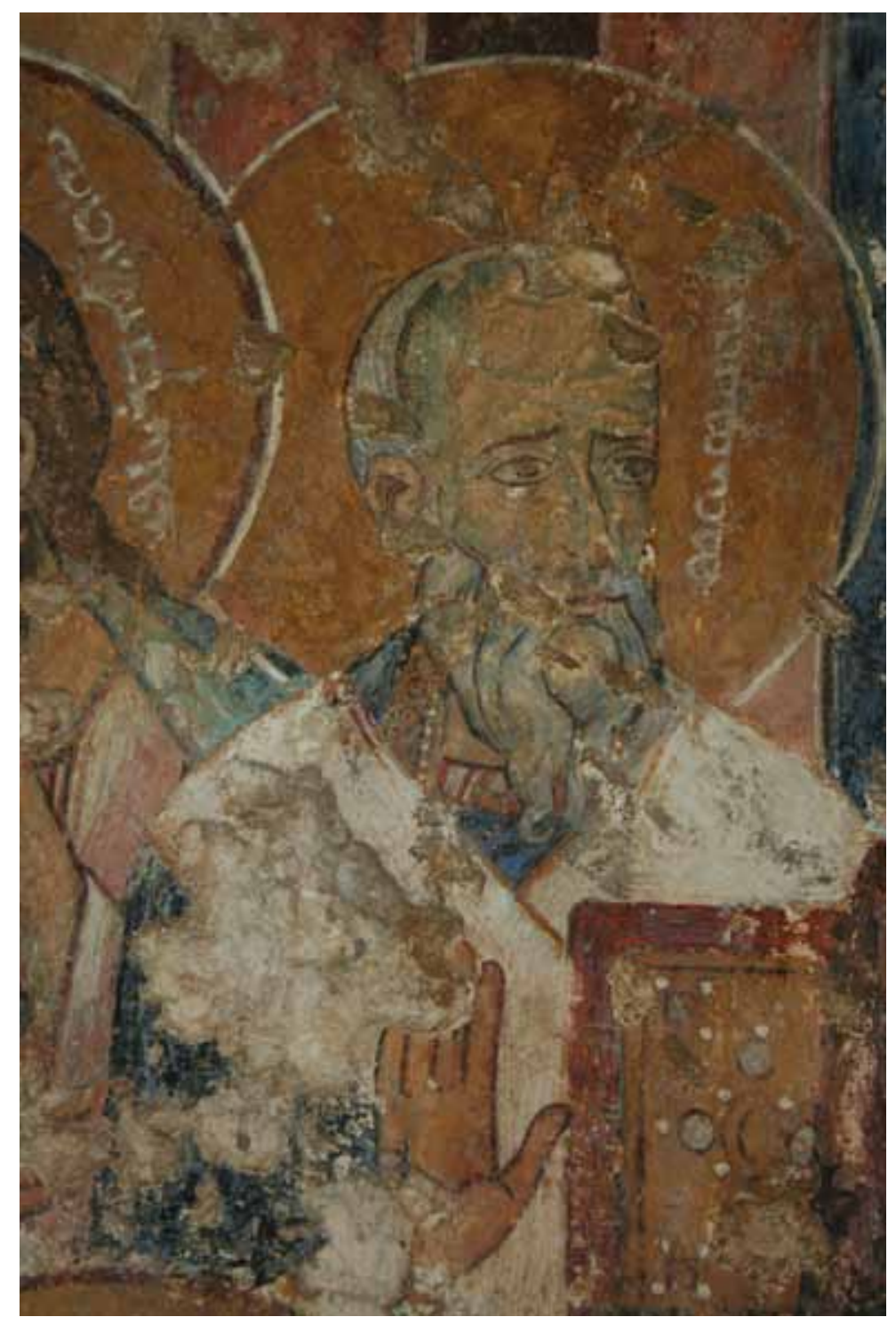

Ill. i9 - Eddé, Liban, Église Saint-Saba, fragment de la Dormition de la Vierge, Denis l'Aréopagite, fresque (vers I 200). 


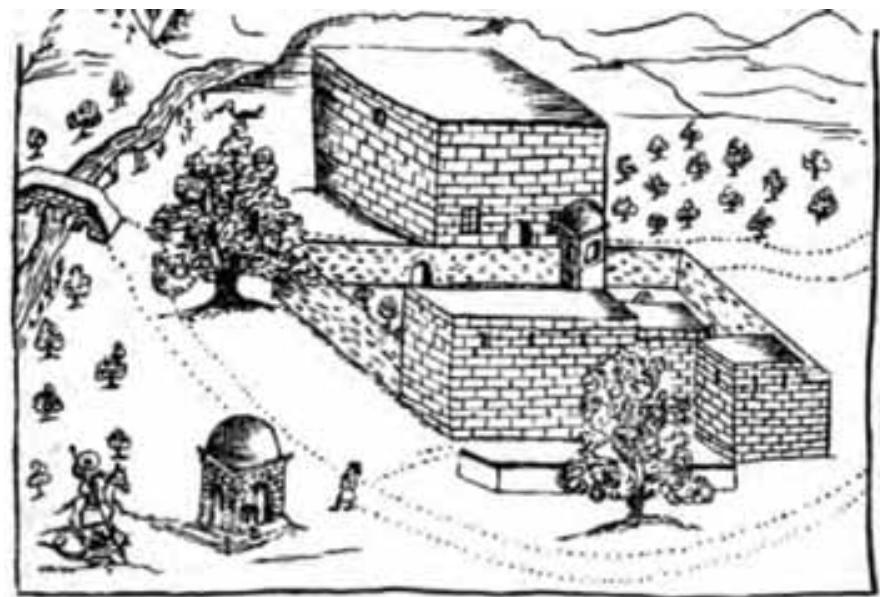

Ill. 20 - Saint-Georges Al-Khodr, dessin fait par le pèlerin russe V. Barsky, 1728 .

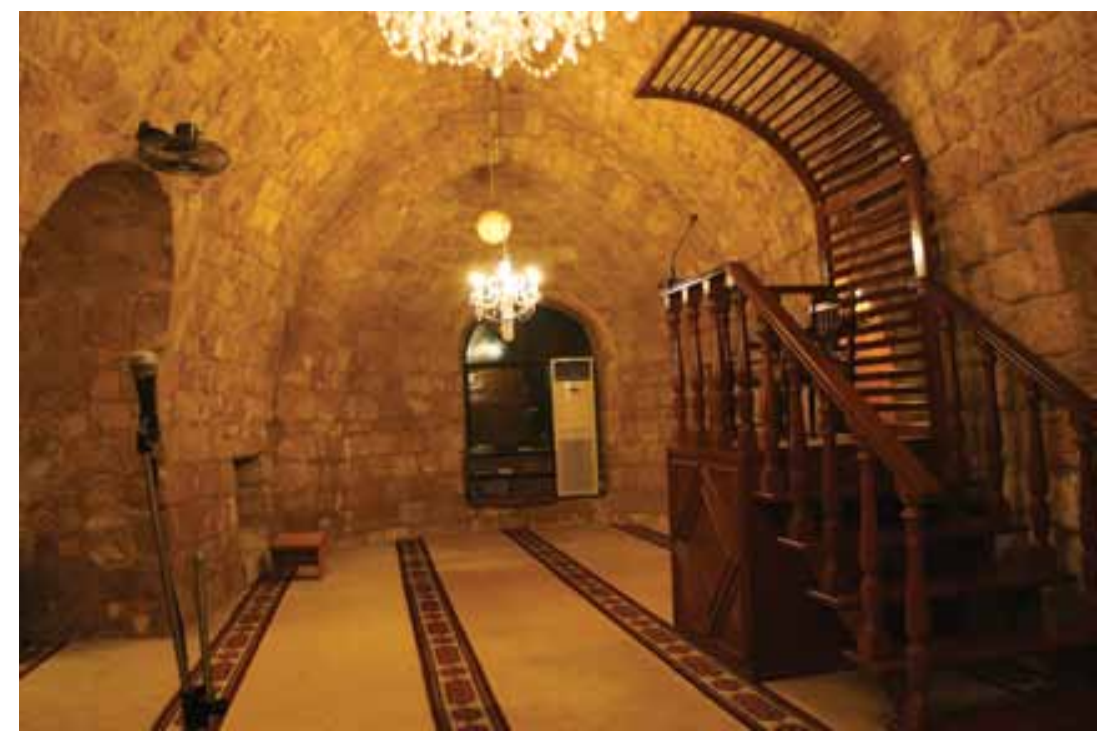

Ill. 2 I - Saint-Georges Al-Khodr, intérieur de la mosquée, ancienne chapelle médiévale. 


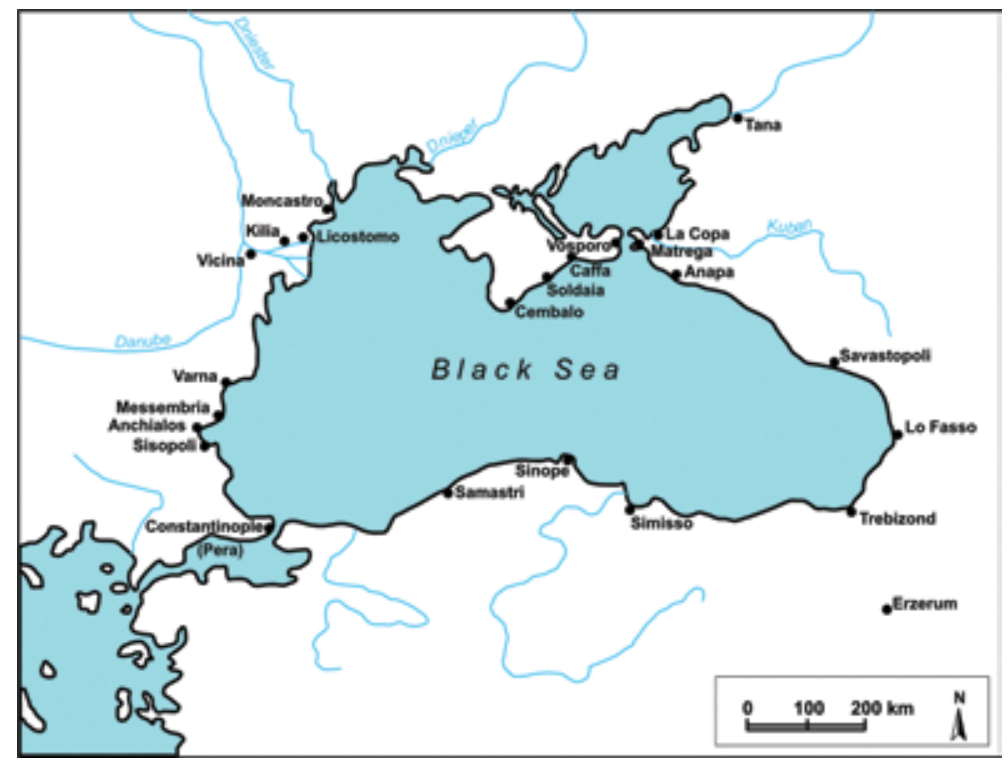

Ill. 22 - Black Sea, the location of the major ports, mainly - Genoese facto-

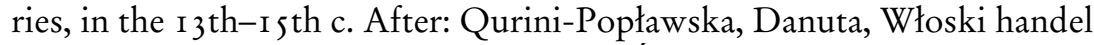
czarnomorskimi niewolnikami w późnym Średniowieczu (Italian Trade of the Black Sea Slaves in the Late Middle Ages), Kraków 2002.

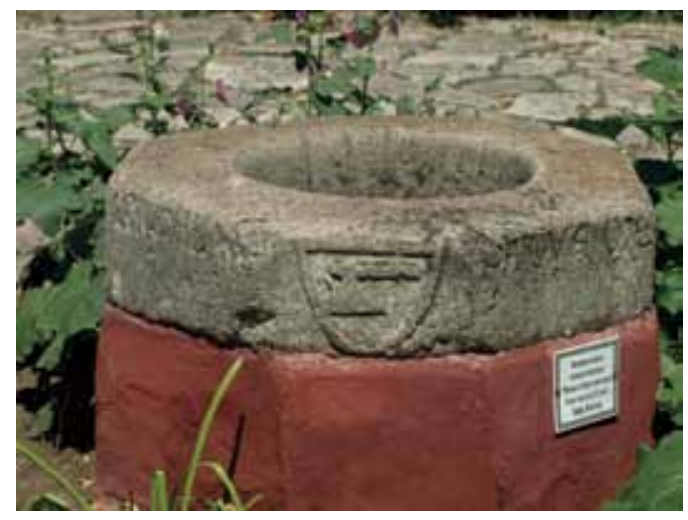

Ill. 23 - Michael of Padua, Well framing, I 33 I, Feodosiya (Caffa), Feodosiya Museum of Antiquities. 


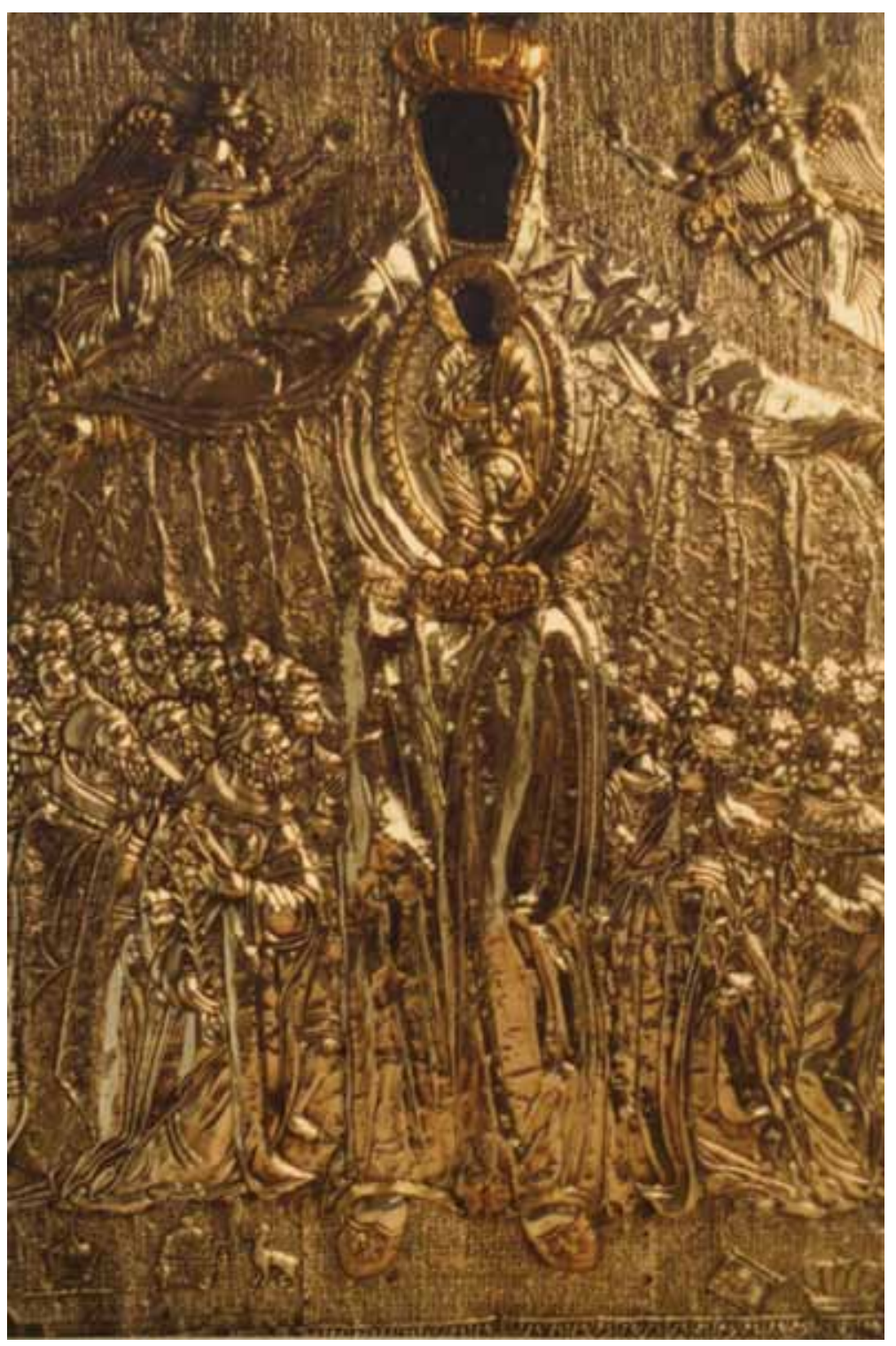

Ill. 24 - Unknown painter, Madonna di Caffa, Panel painting, reconstruction after 1698, Istanbul-Galata, Saints' Peter and Paul Church. 


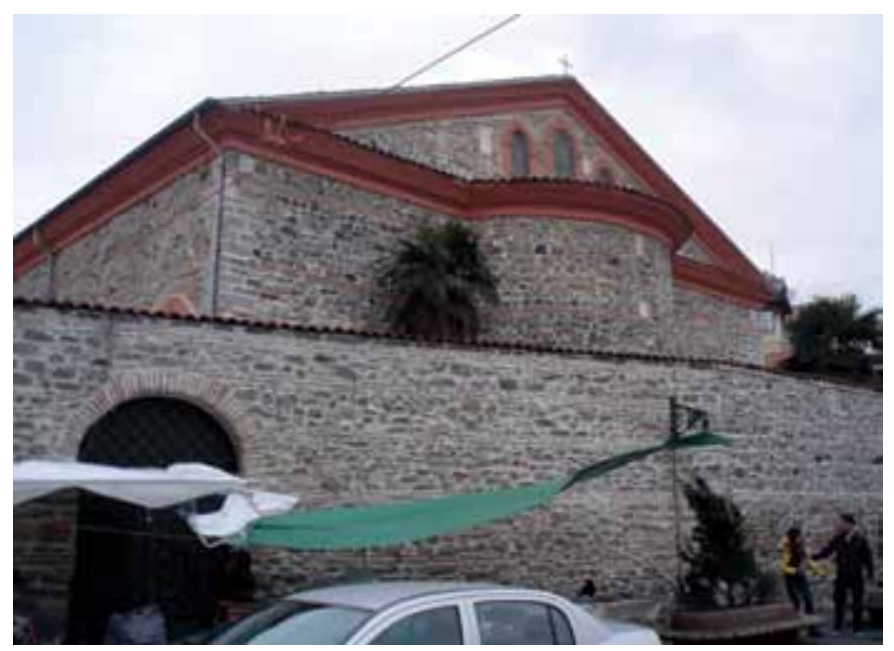

Ill. 25 - Istanbul-Ortaköy, Greek church of Ayios Phocas seen from the north, 1856 .

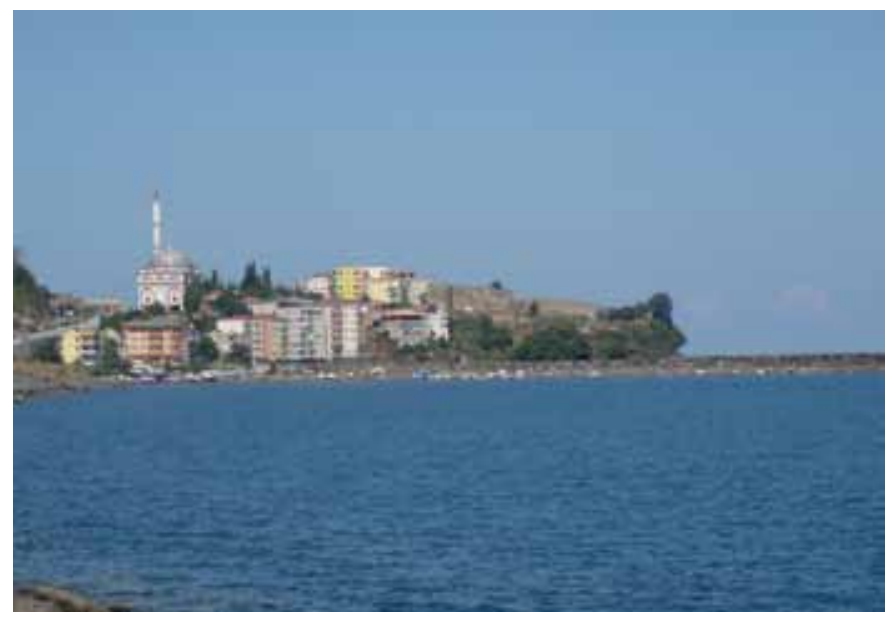

Ill. 26 - Akçakale (Kordyle), Ruins of the fortress Kordyle Kalesi and a place of St. Phocas monastery seen from the east; castle built by emperor Alexios II ( I 297-I 330), monastery founded by emperor Alexios III in I 362 . 


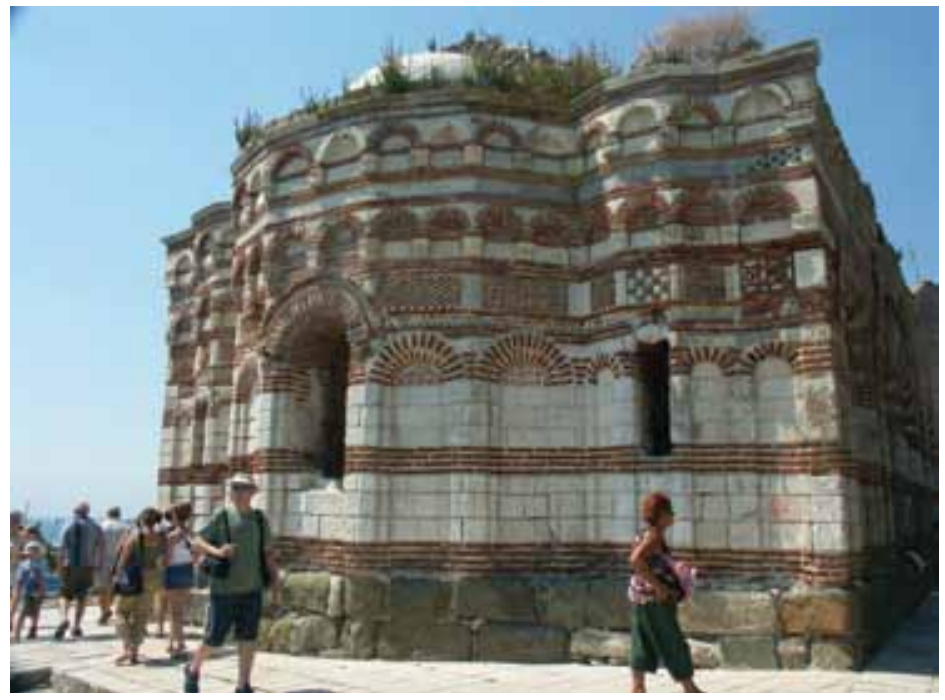

Ill. 27 - Nesebar (Mesembria), Ruins of the church of St. John Aliturgetos seen from the east, early i 4 th $c$.

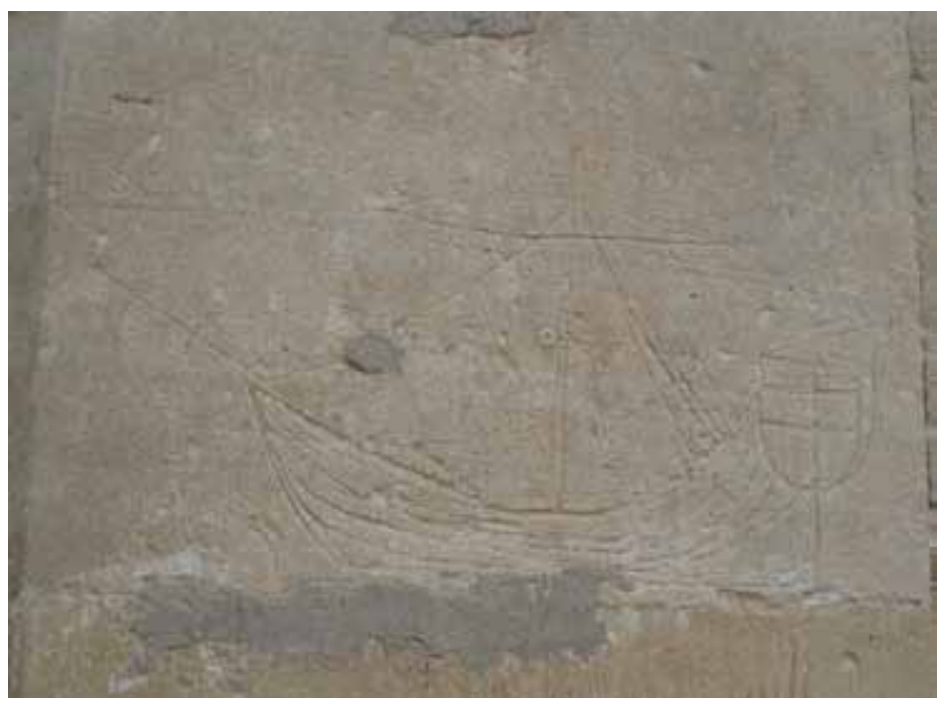

Ill. 28 - Trabzon (Trebizond), Haghia Sophia, central apse, Ship (karabia or (og), graffiti, pre-I46I. 


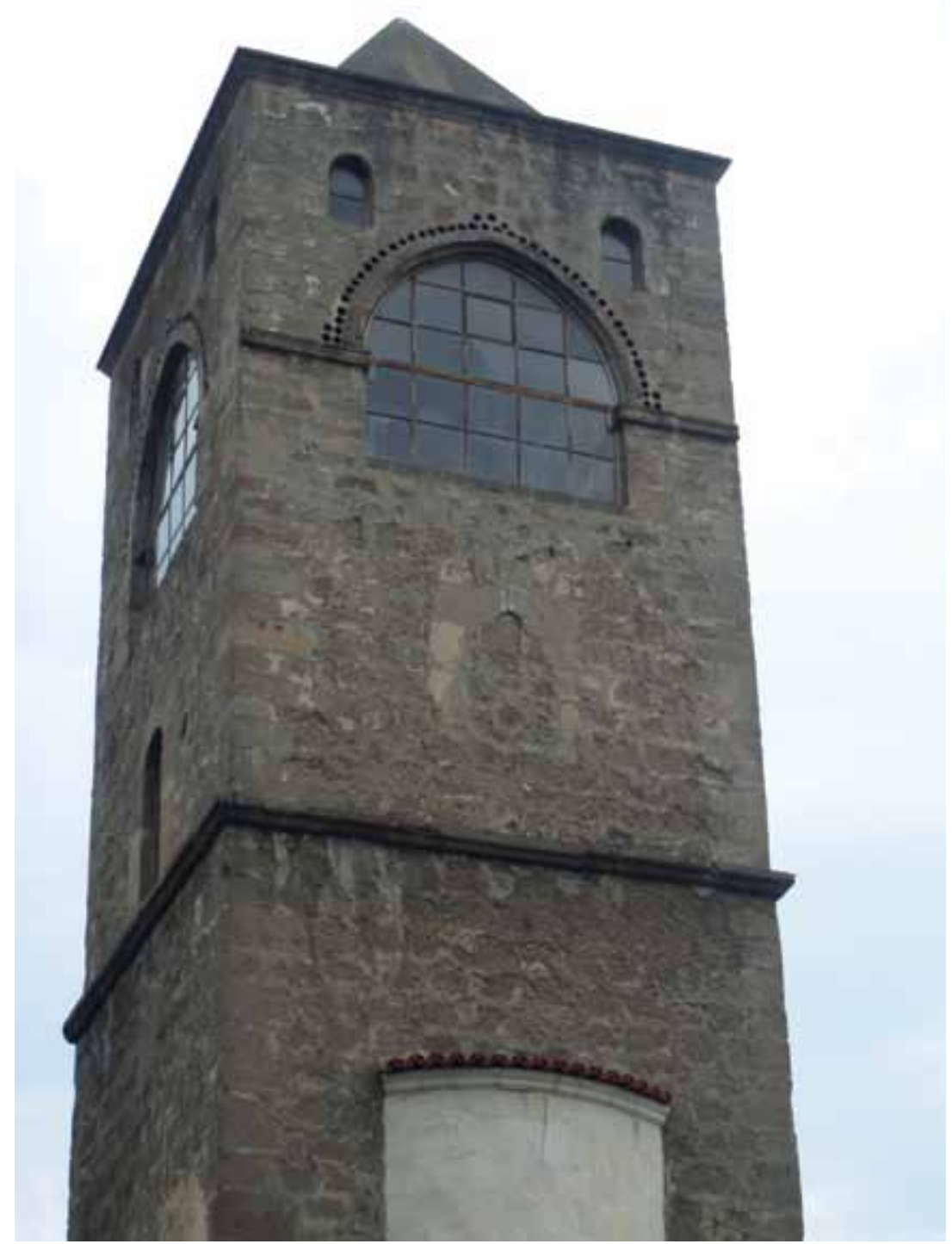

Ill. 29 - Trabzon (Trebizond), Bell tower by Hagia Sophia, I 427. 


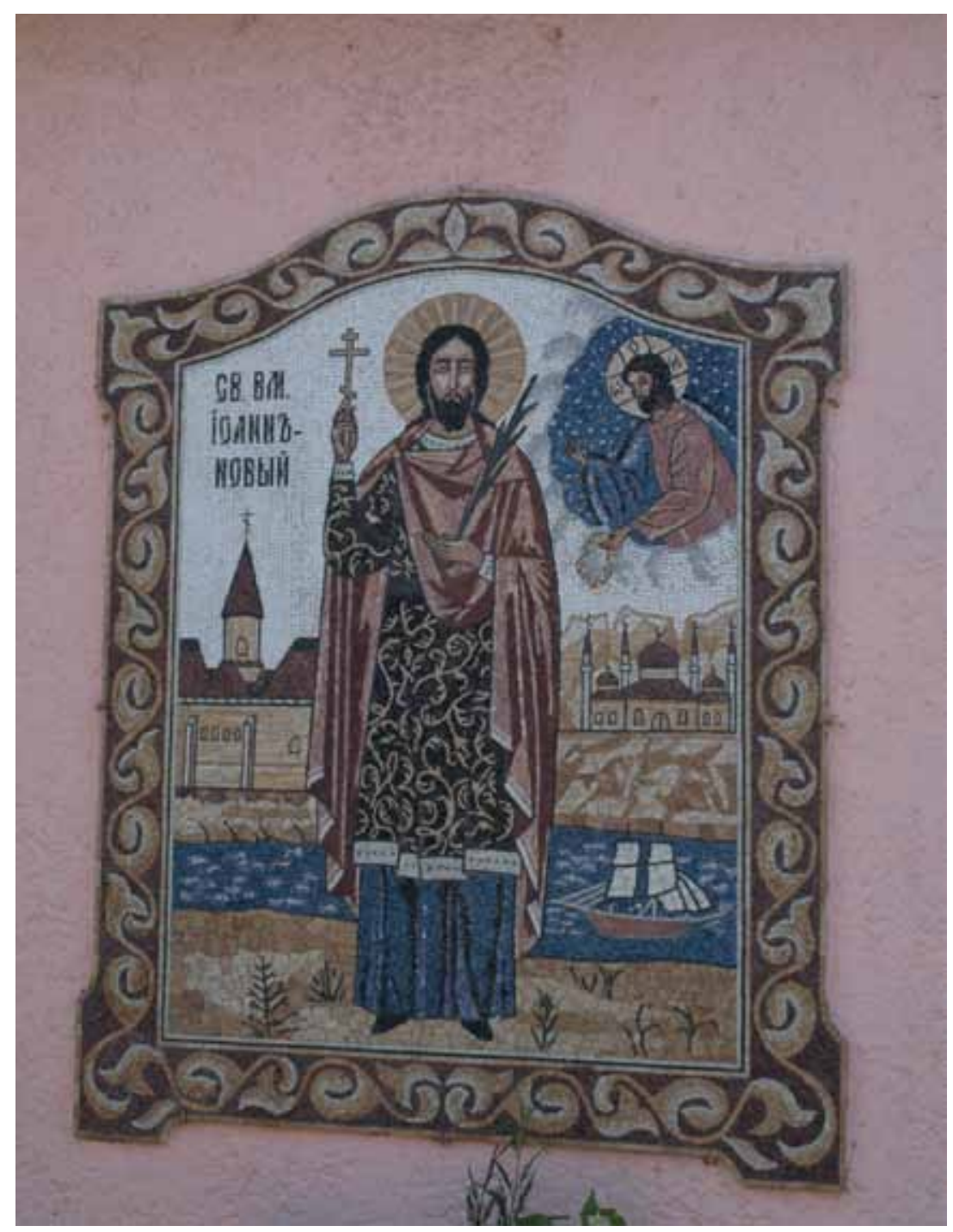

Ill. 30 - Bilhorod-Dnistrovskyi (Moncastro), wall of the partially underground chapel of Saint John the New, Saint John the New, contemporary mosaic. 


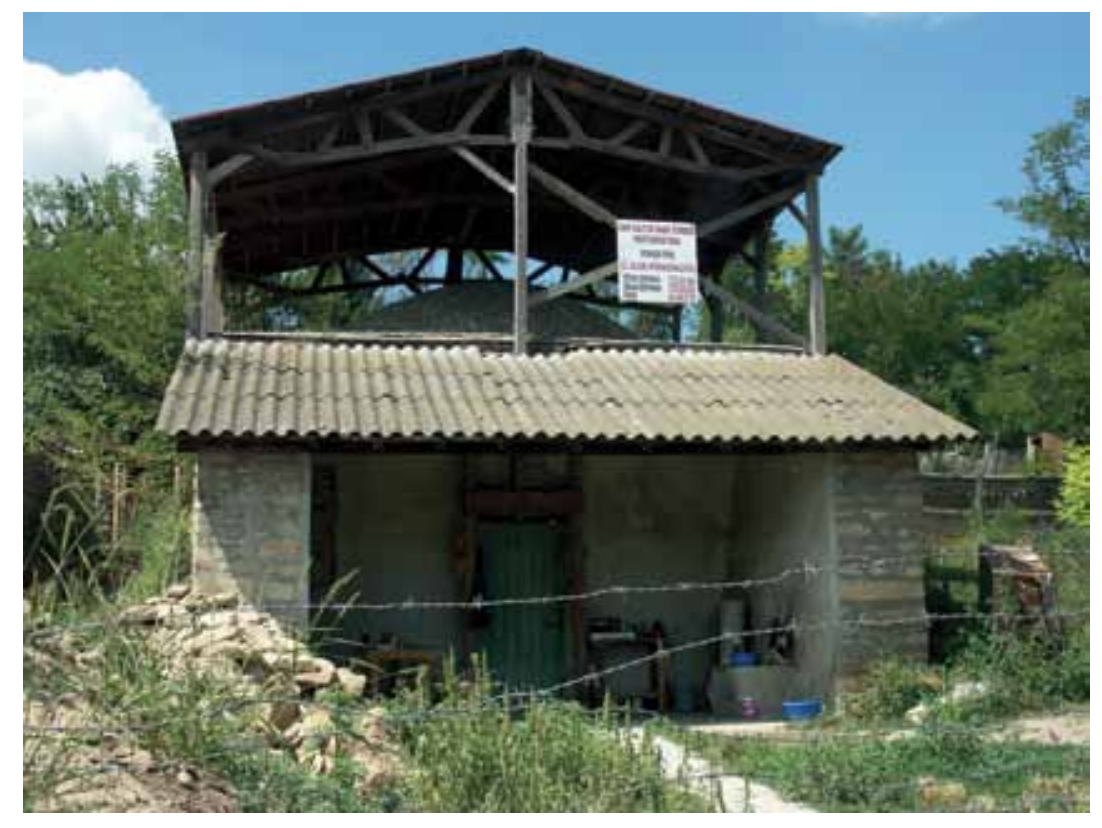

Ill. 3 I - Babadag (Babadağ), Türbe of Sari Saltik, i sth c., during the restoration in 2006. 


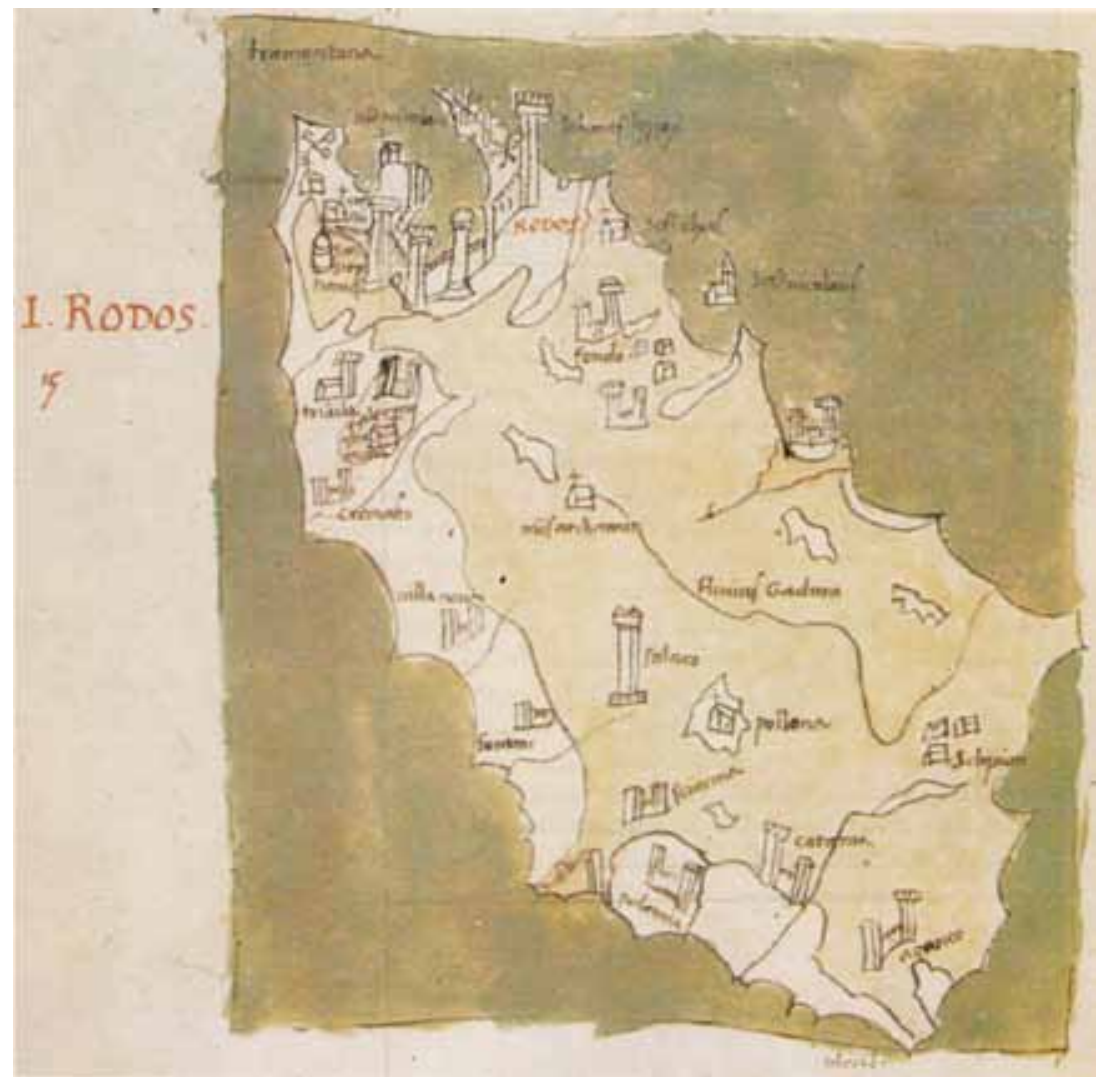

Ill. 32 - L'isola di Rodi descritta da Cristoforo Buondelmonti. Foto in Tó

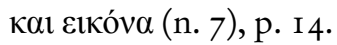




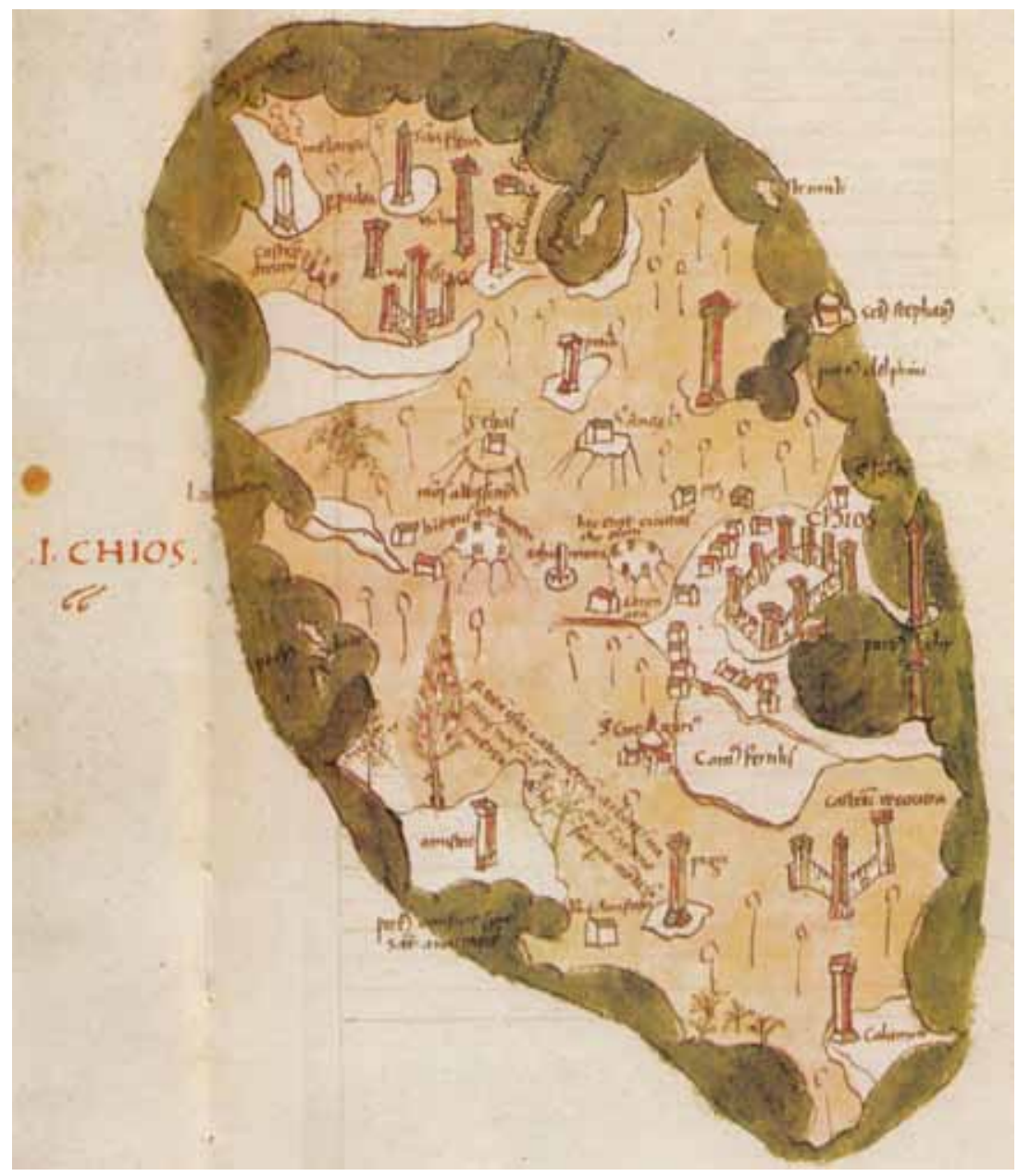

Ill. 33 - L'isola di Chio descritta da Cristoforo Buondelmonti. Foto in Tó $\pi$ os

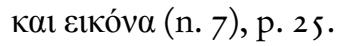




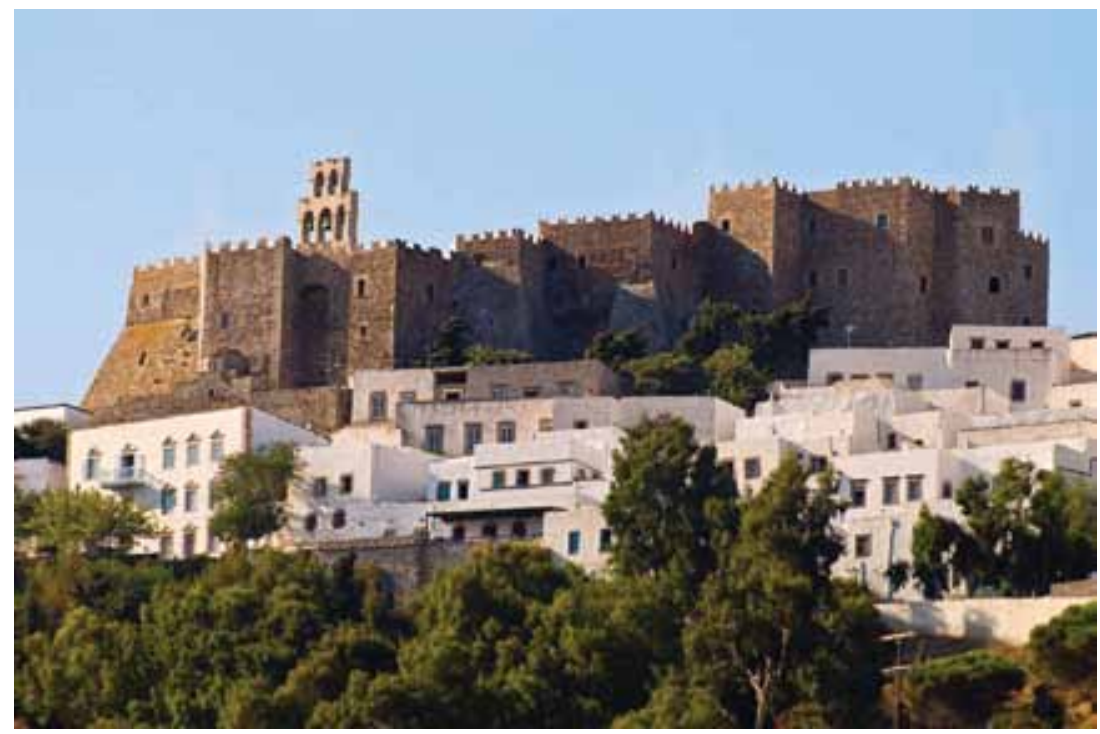

Ill. 34 - Patmos, il monastero di San Giovanni Teologo.

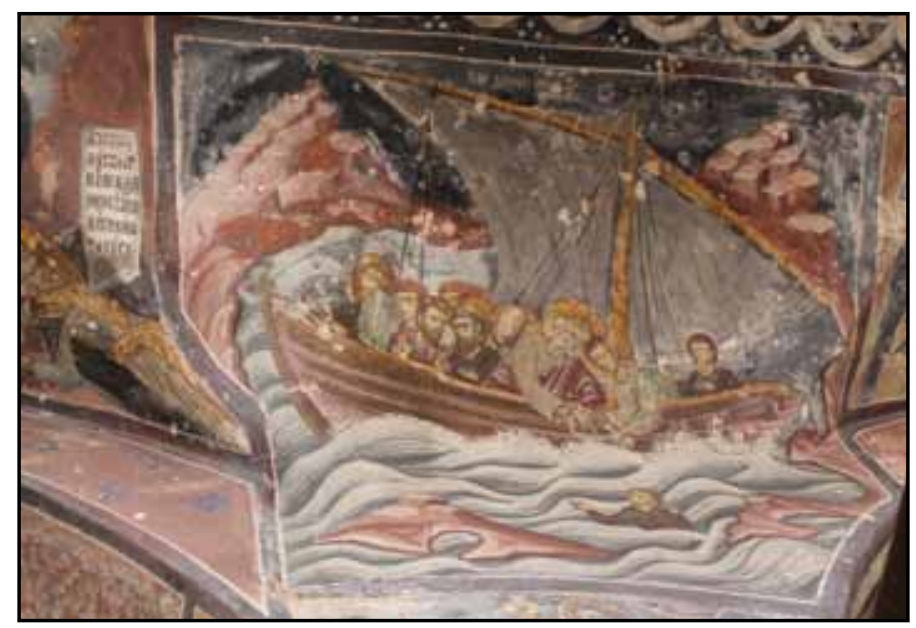

Ill. 35 - Patmos, monastero di San Giovanni Teologo, pittura murale nel nartece esterno, San Giovanni salva un ragazzo caduto nel mare (Archivio Fotografico della 4a Soprintendenza alle Antichità Bizantine, Grecia). 


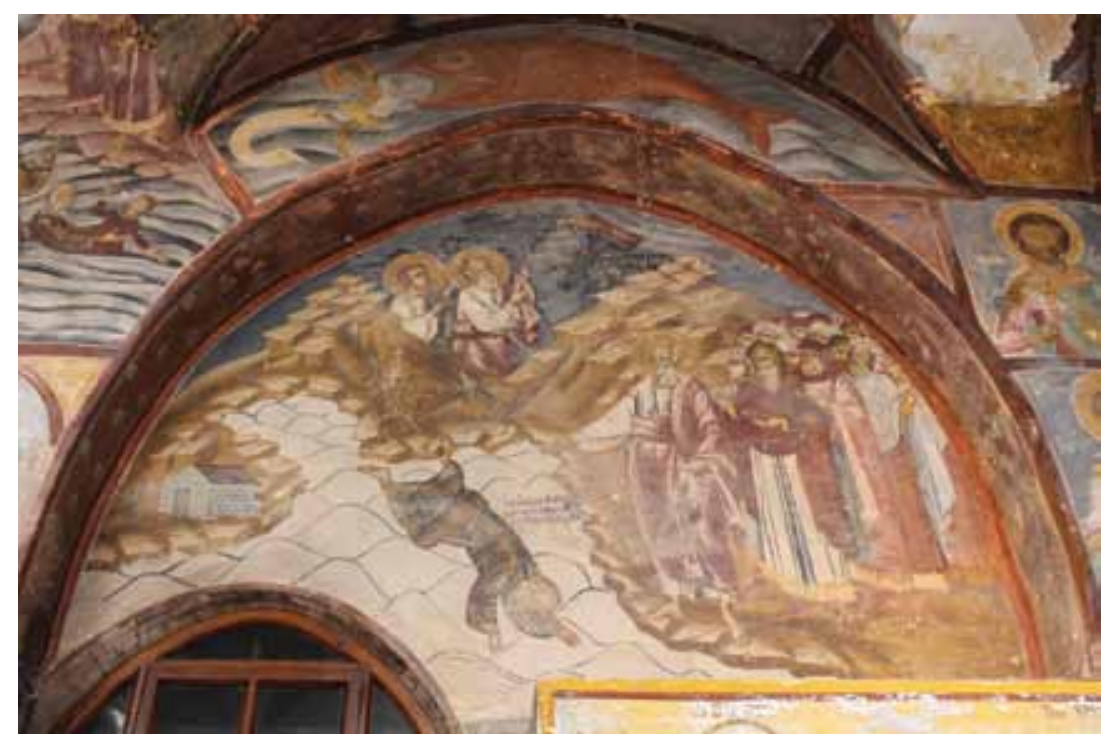

Ill. 36 - Patmos, monastero di San Giovanni Teologo, pittura murale nel nartece esterno, San Giovanni getta nel mare il mago dell'isola di Patmos (Archivio Fotografico della 4a Soprintendenza alle Antichità Bizantine, Grecia). 


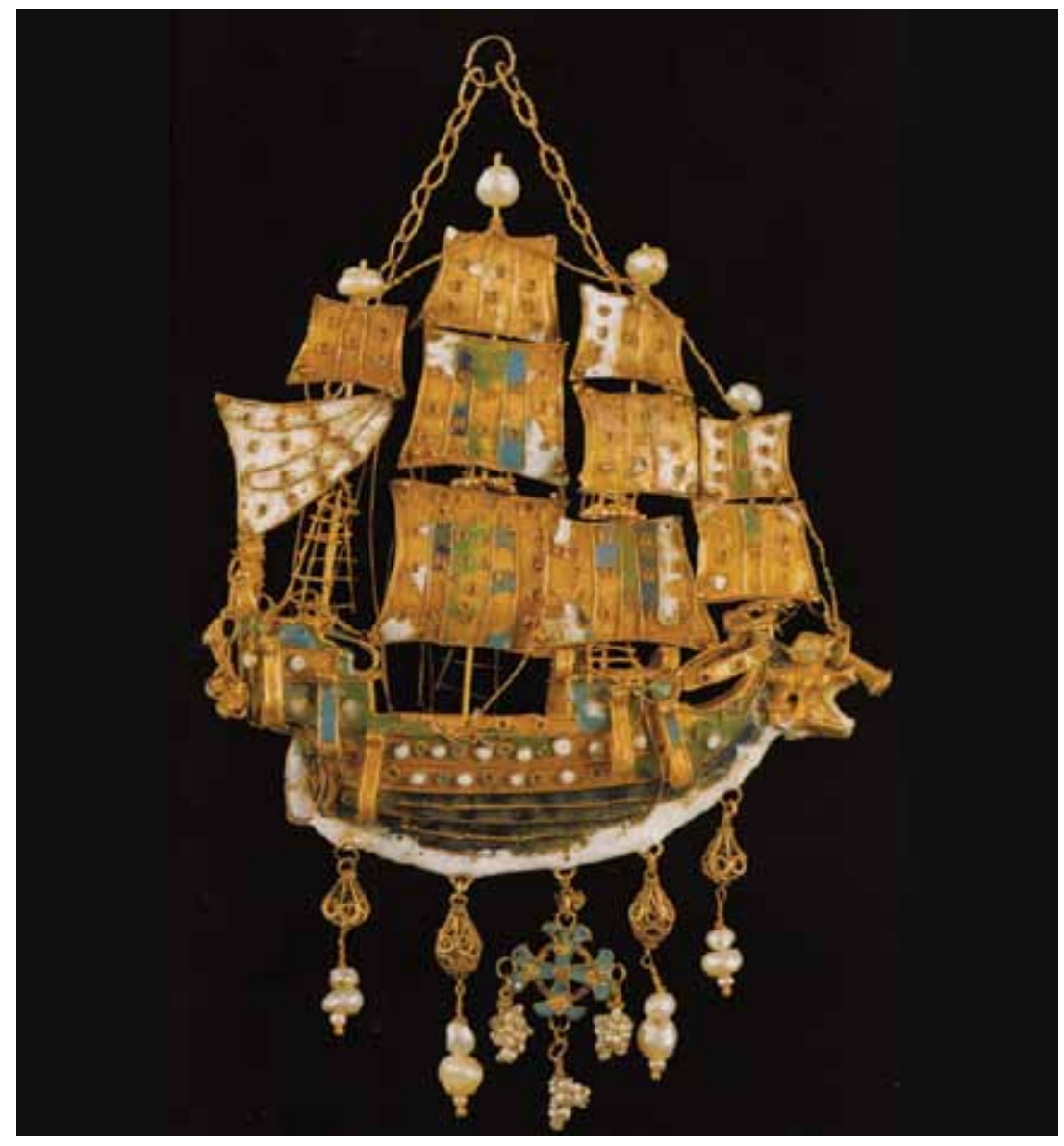

Ill. 37 - Patmos, Monastero di San Govanni Teologo, Amuleto con la rappre-

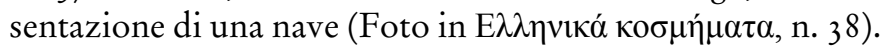




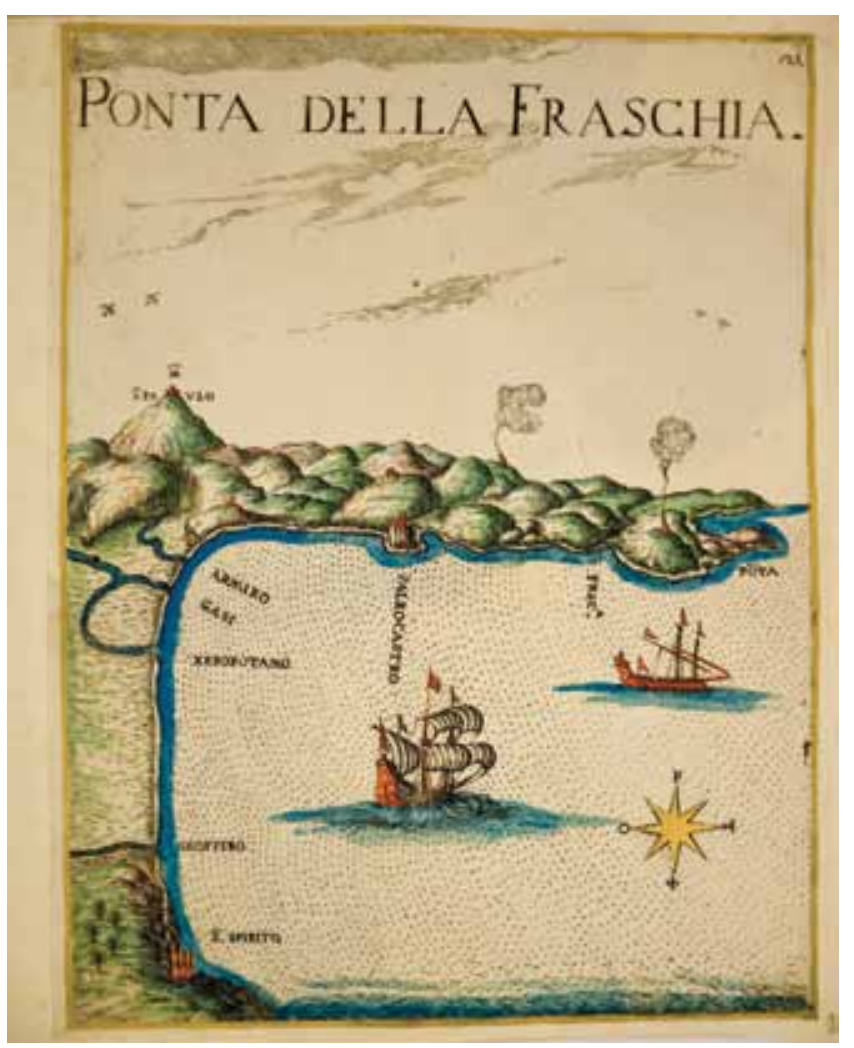

Ill. 38 - Ponta della Fraschia, in: Boschini, Marco, Il Regno tutto di Candia delineato a parte a parte et intagliato da Marco Boschini venetiano. Al Serenissimo Prencipe e Regal Collegio di Venetia M.D.C.LI. Con privilegio nelli stati della Chiesa e della Republica di Venetia, i65 I (The Gennadius Library, American School of Classical Studies at Athens, GT 229 q, 24r 2). 


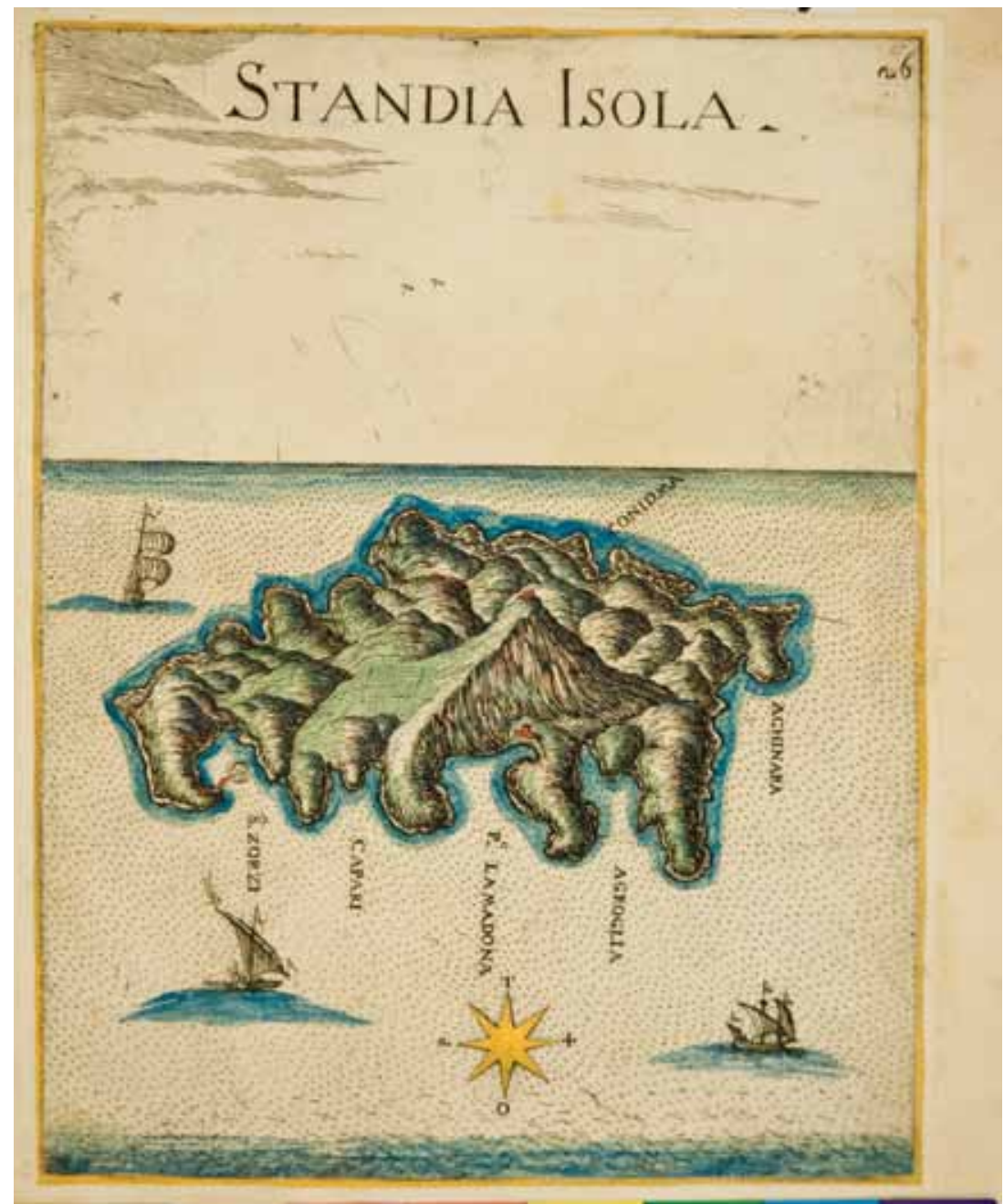

Ill. 39 - Isola della Standia, in: Il Regno tutto di Candia delineato a parte a parte et intagliato da Marco Boschini venetiano, 165 I. (The Gennadius Library, American School of Classical Studies at Athens, GT 229 q, 24Z). 


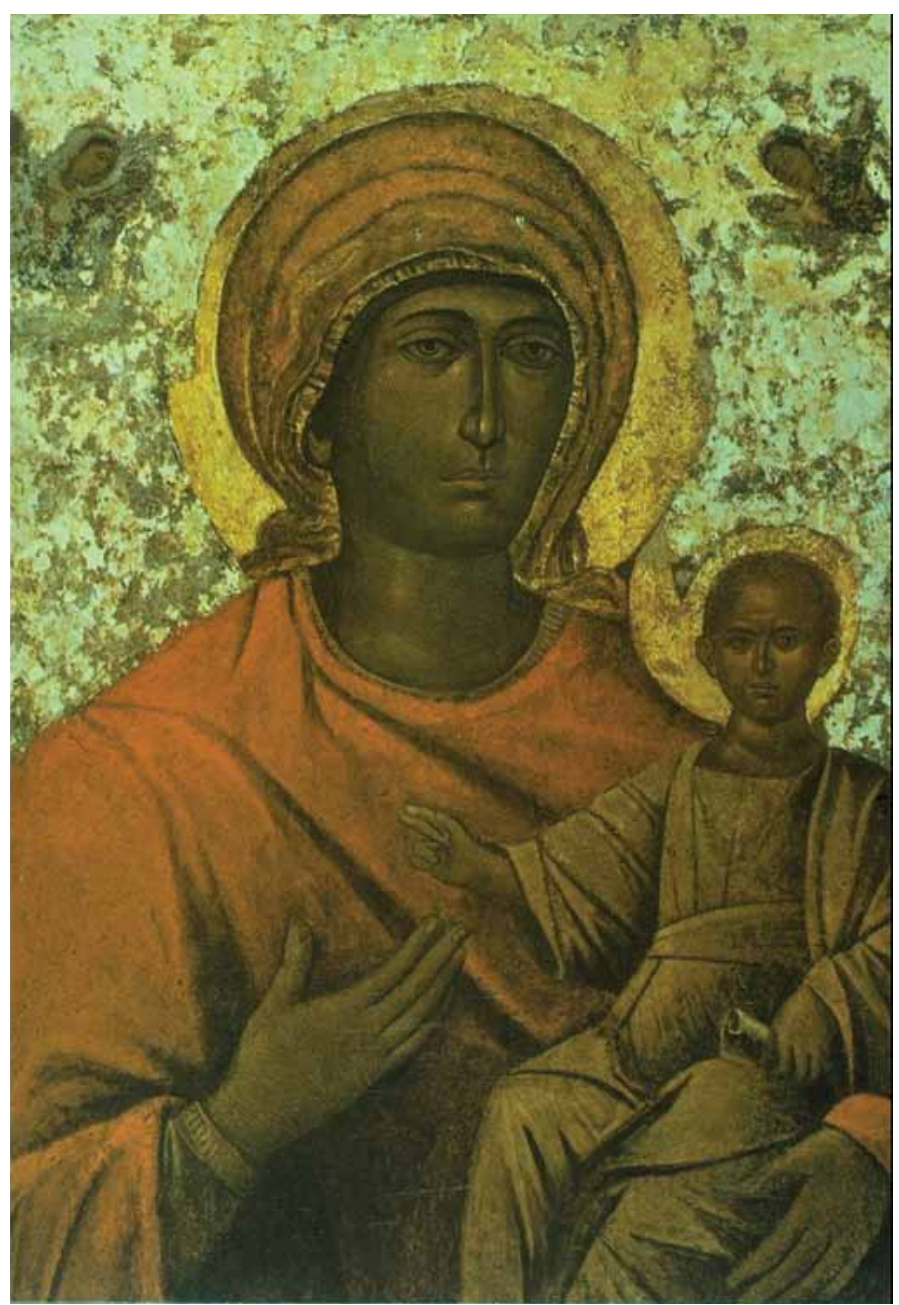

Ill. 40-Icon of the Virgin Mesopanditissa, now at the church of Santa Maria della Salute, Venice (Photo Böhm, Venezia). 


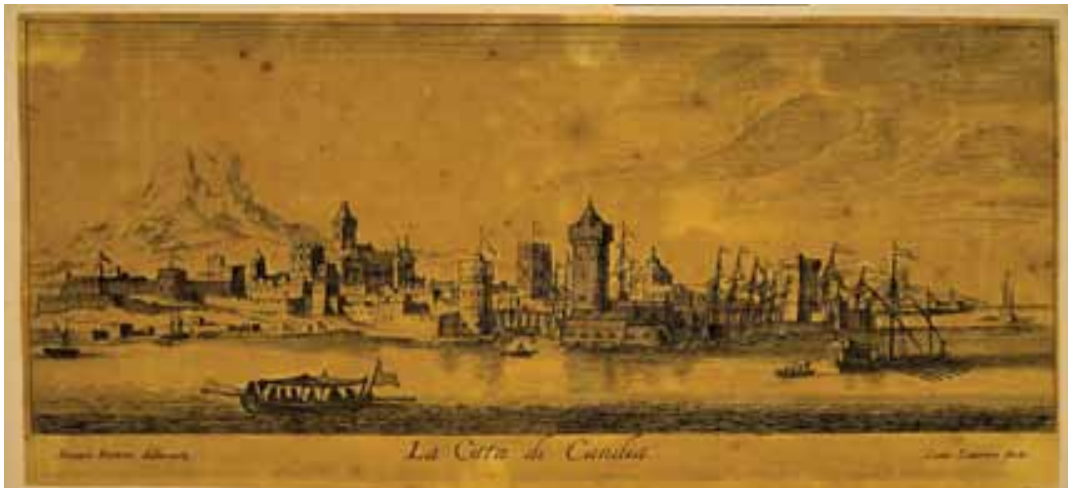

Ill. 4 I - View of Candia, in: Ioannes Peeters, La Città di Candia, circa I665 (The Gennadius Library American School of Classical Studies at Athens, GT 229 q, 24x b).

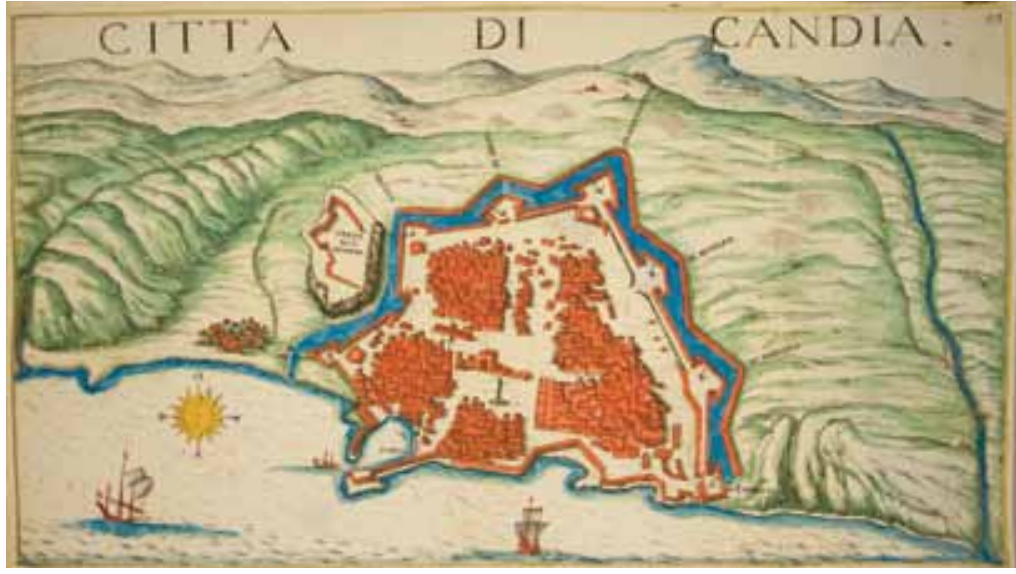

Ill. 42 - Topographical view of Candia, in: Il Regno tutto di Candia delineato a parte a parte et intagliato da Marco Boschini venetiano, I65 I (The Gennadius Library American School of Classical Studies at Athens, GT 229 q, 24x a). 


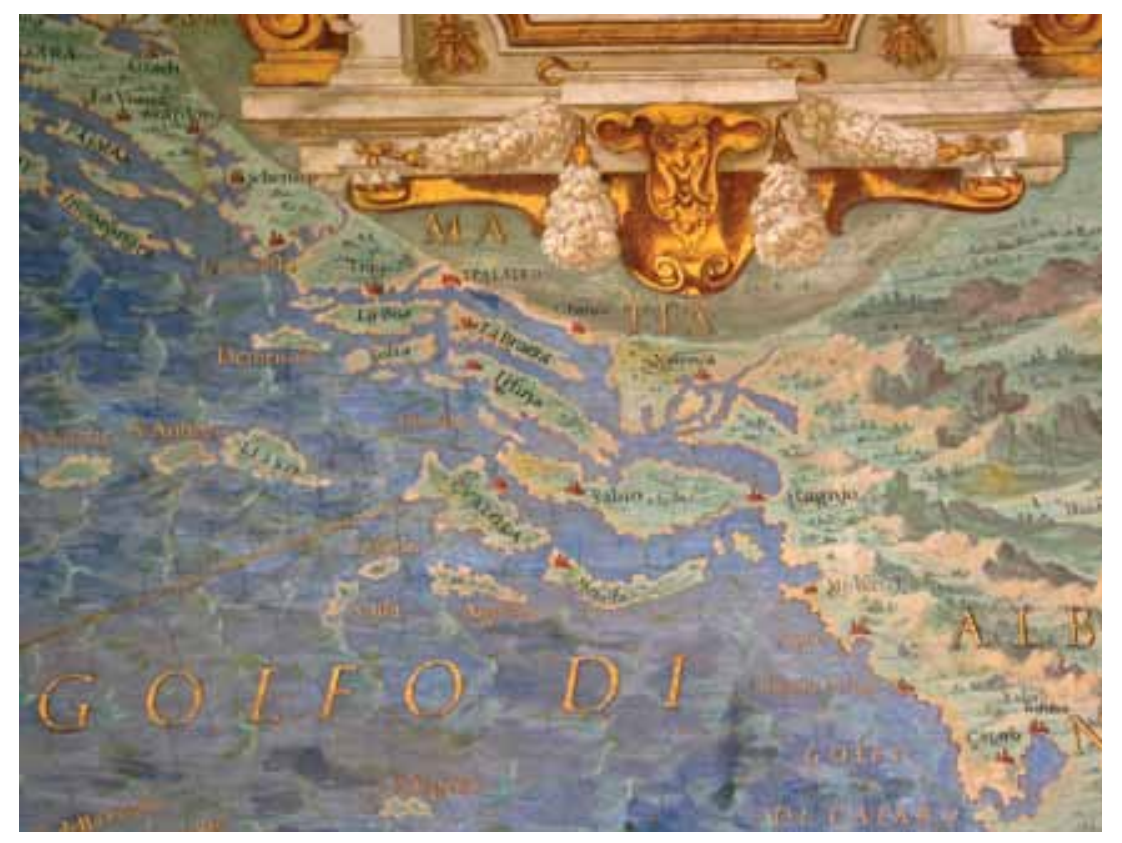

Ill. 43 - Egnazio Danti, La Galleria delle carte geografiche in Vaticano (I $572-1585)$. 


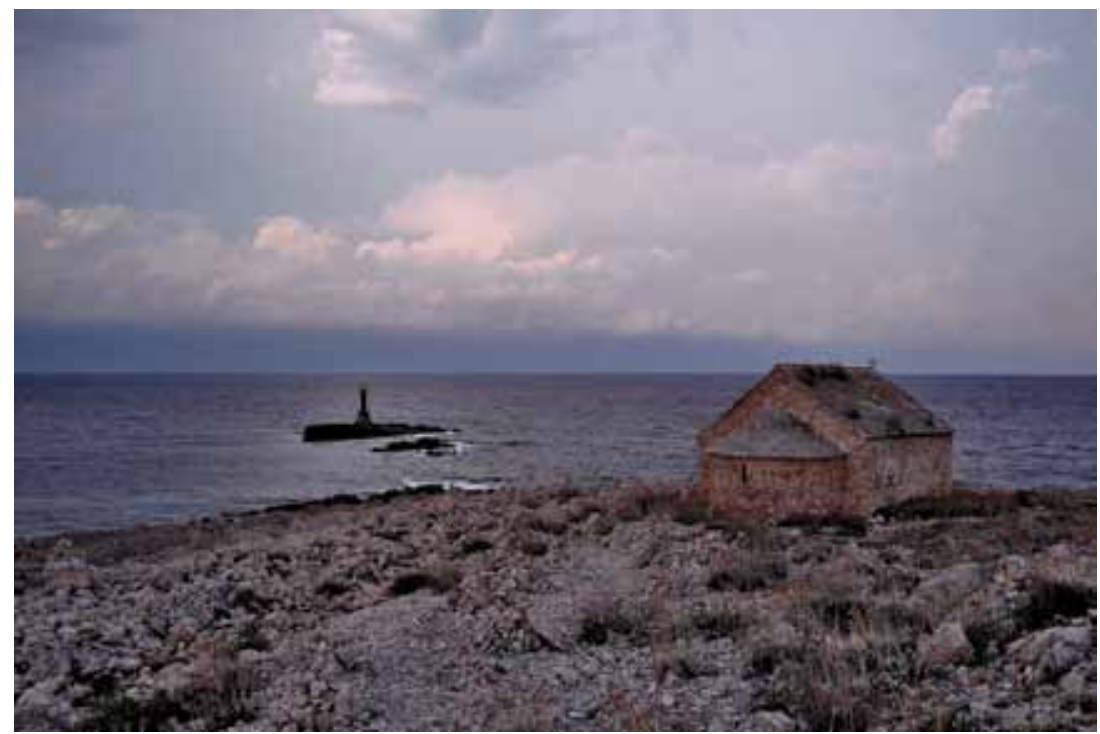

Ill. 44 - Cape Ploča with chapel of St. John of Trogir (Foto A. Katić).

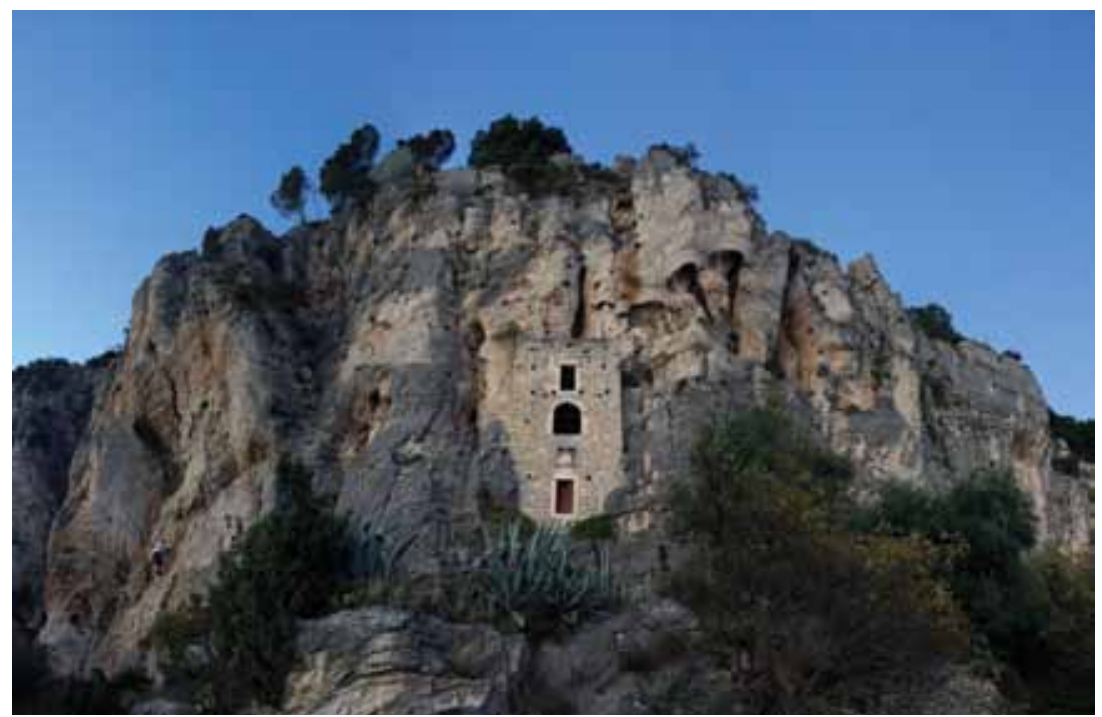

Ill. 45 -Split, Marjan, a I6th century hermitage under Santine stine. 


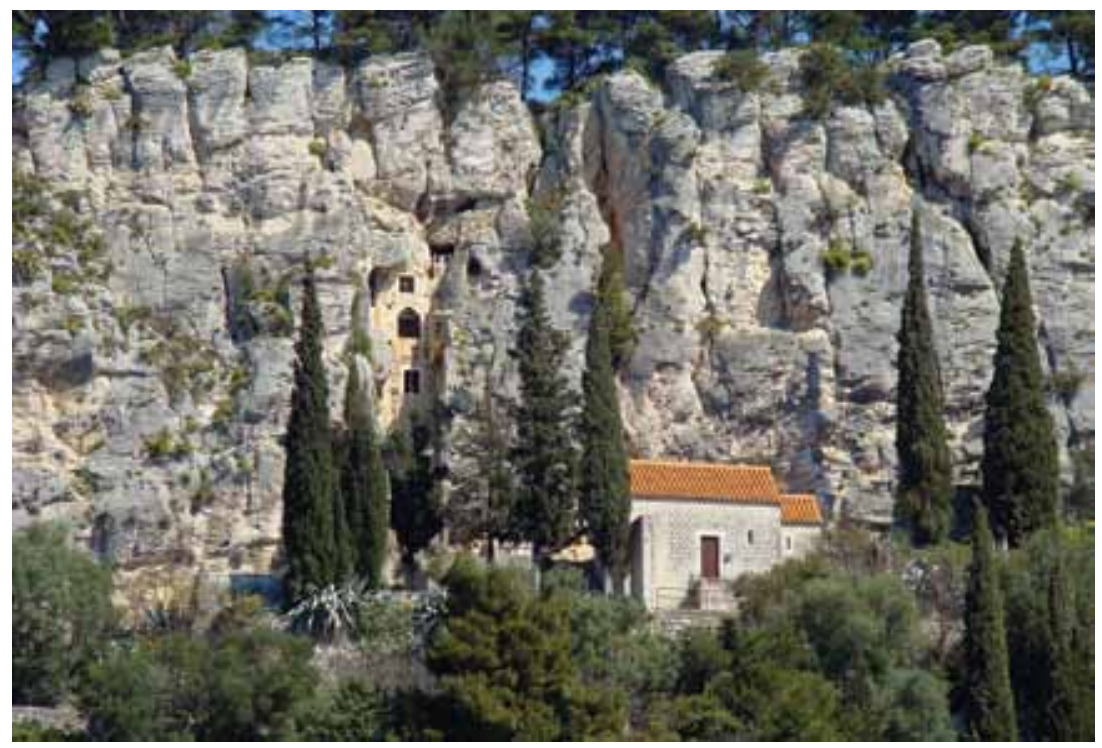

Ill. 46 - Split, Marjan, hermitage of St. Jerome.

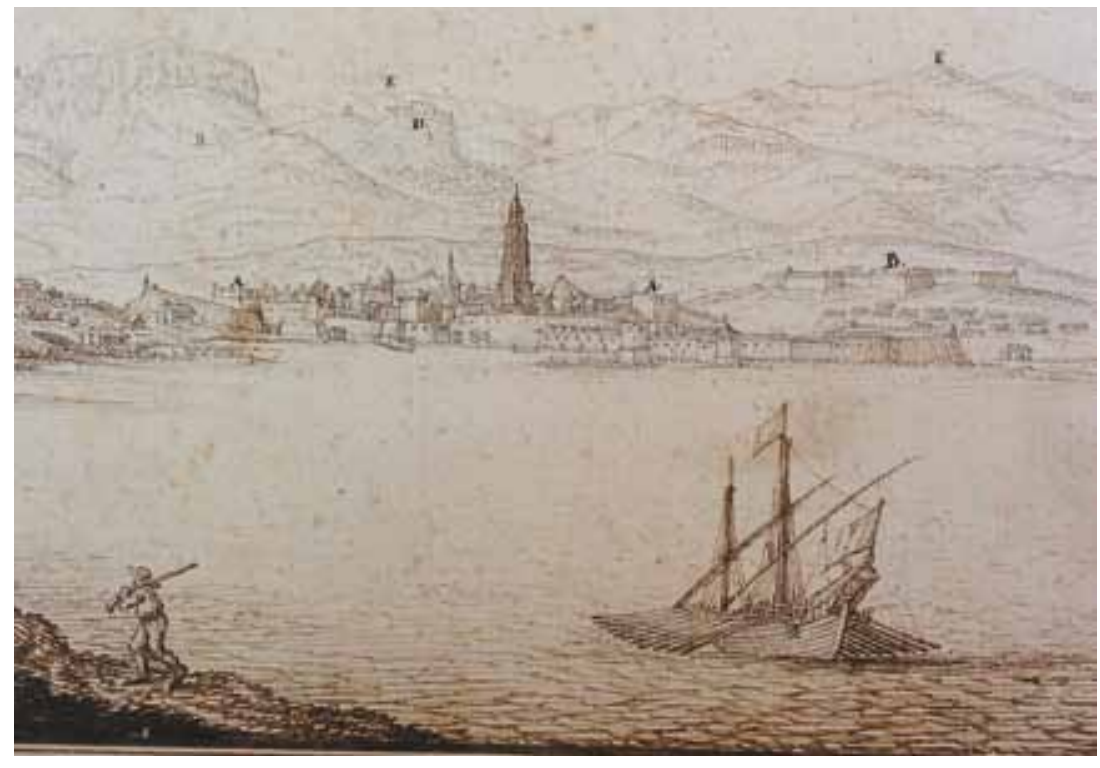

Ill. 47 - Giuseppe Santini, Split in I666, City Museum of Split. 


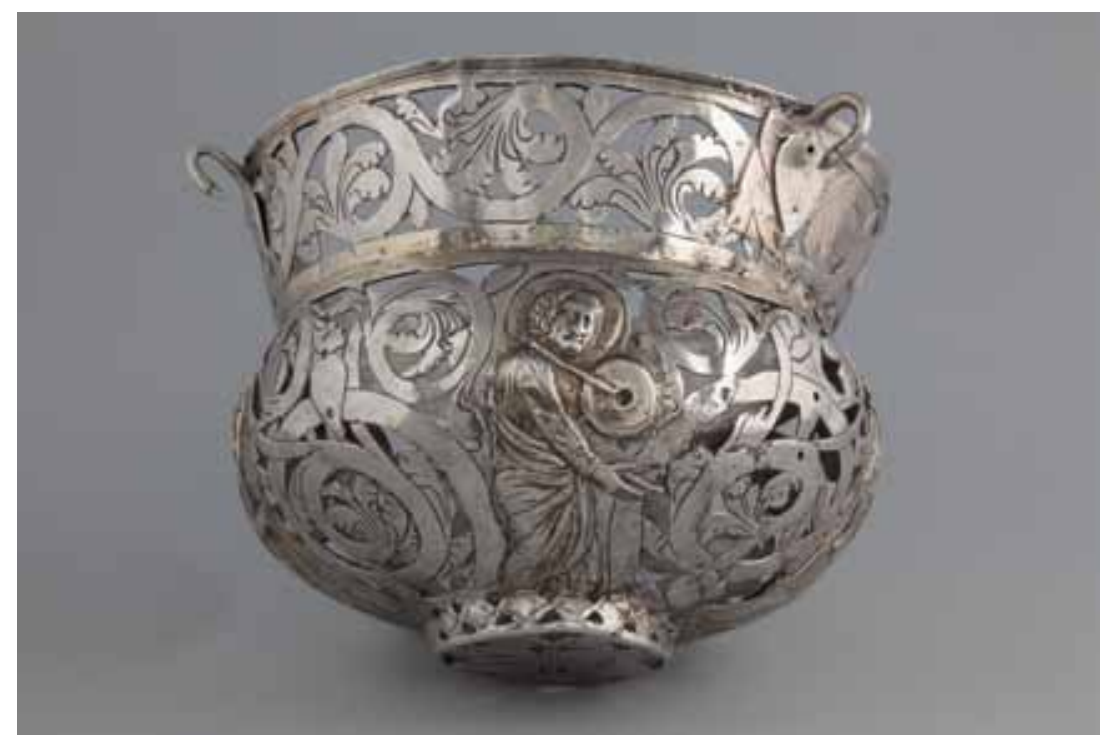

Ill. 48 - Zadar and split Goldmiths, painters and miniaturists Matheus and Aristodius (attr.), Romanesque hanging lamps with depictions of St. Anastasius, St. Domnius and Christ. Silver, partially gilt, hammered open-work (1210?). 


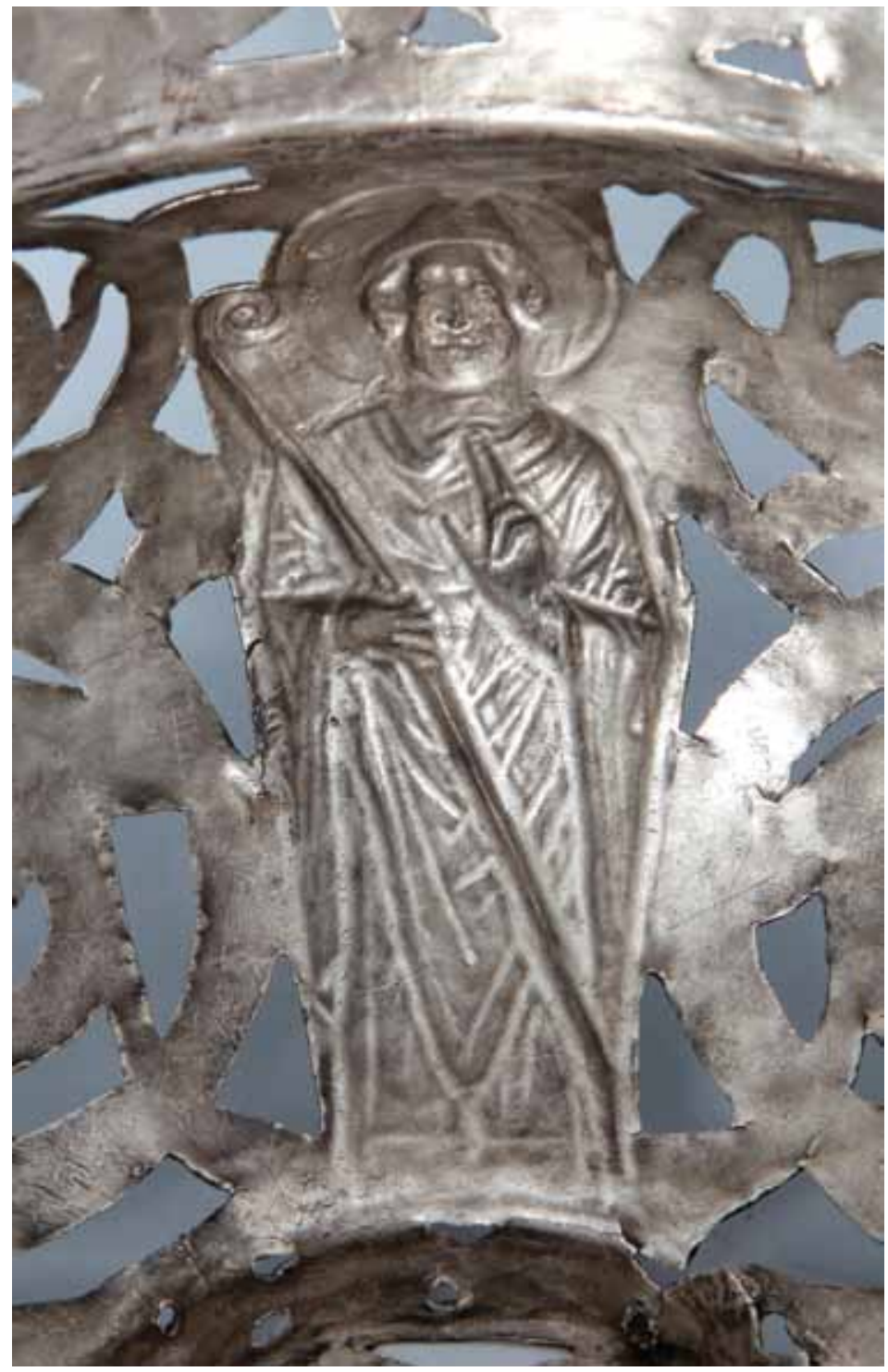

Ill. 49-Zadar and split Goldmiths, painters and miniaturists Matheus and Aristodius (attr.), Romanesque hanging lamps with depictions of St. Anastasius, St. Domnius and Christ. Silver, partially gilt, hammered open-work (I 2I0?). 


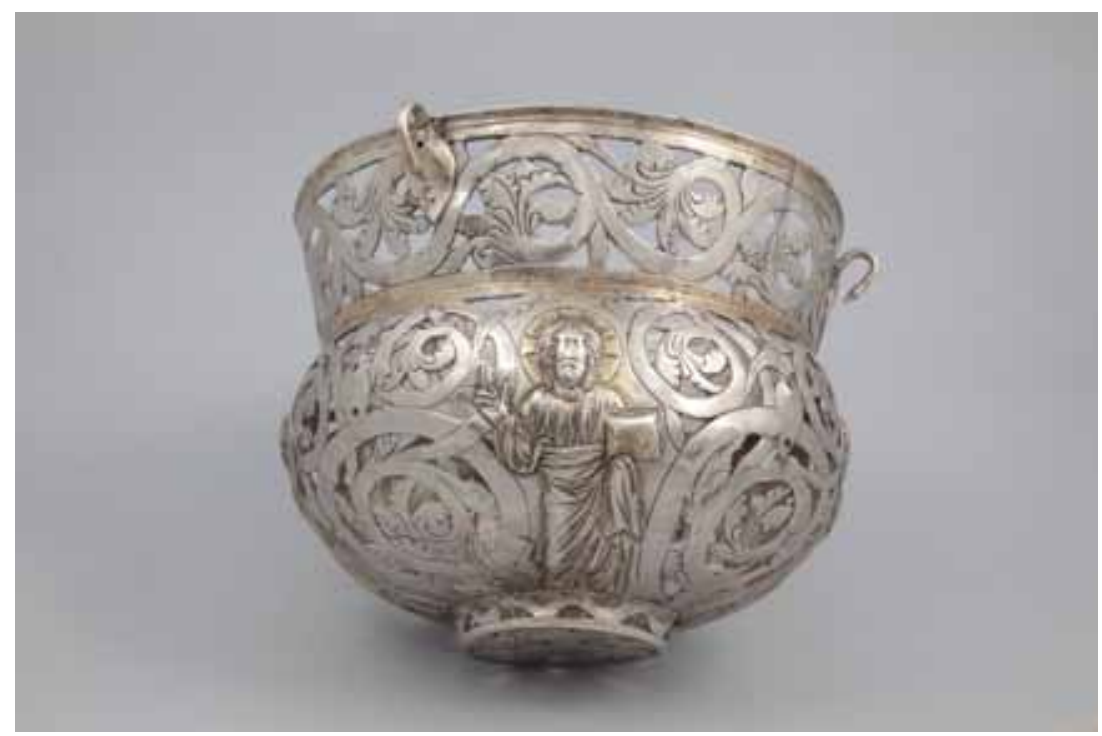

Ill. 50-Zadar and split Goldmiths, painters and miniaturists Matheus and Aristodius (attr.), Romanesque hanging lamps with depictions of St. Anastasius, St. Domnius and Christ. Silver, partially gilt, hammered open-work (I 2 IO?). 


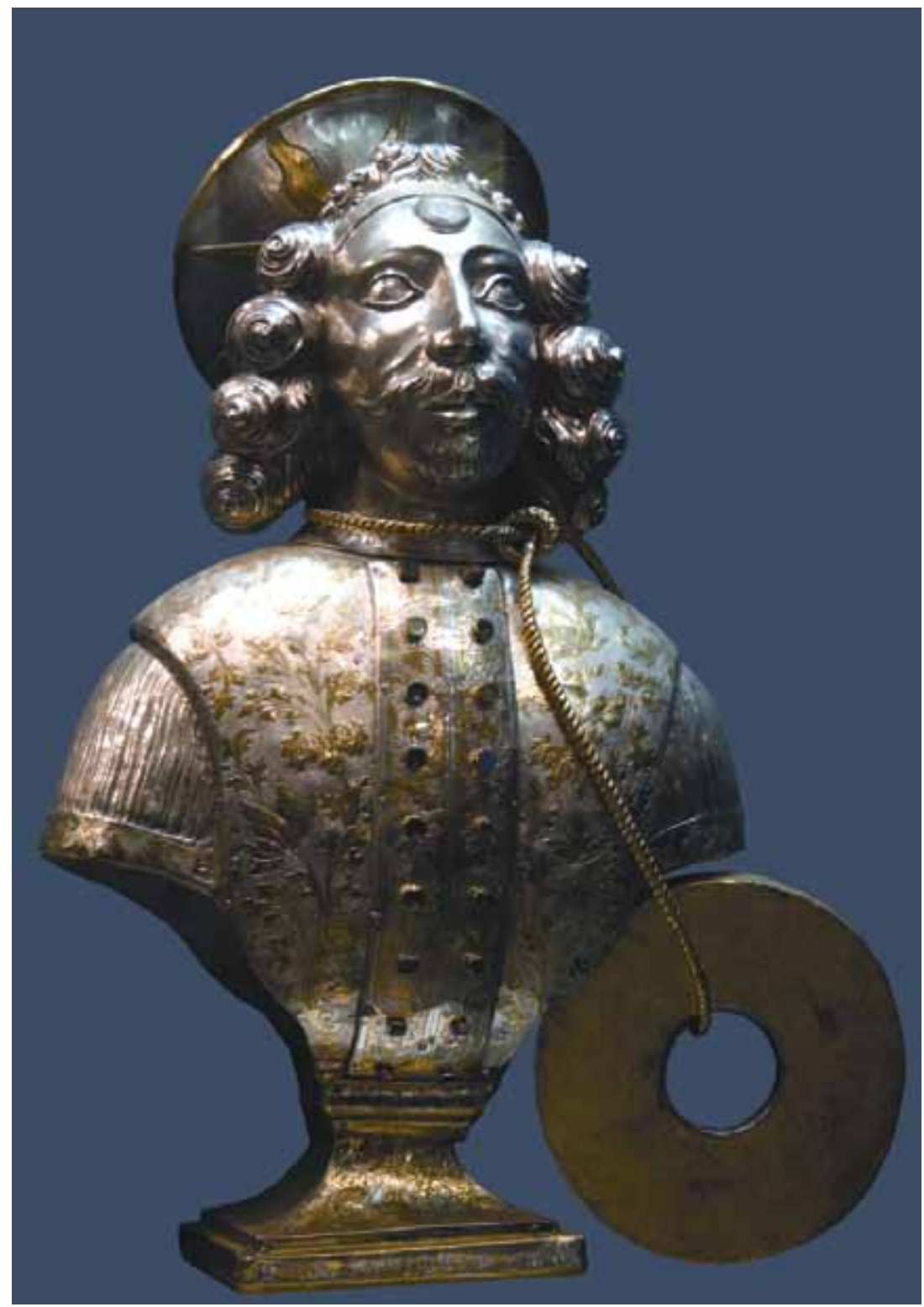

Ill. 5 I - G. B. Trevisan, reliquary of St. Anastasius ( I704), treasury of Split Cathedral. 

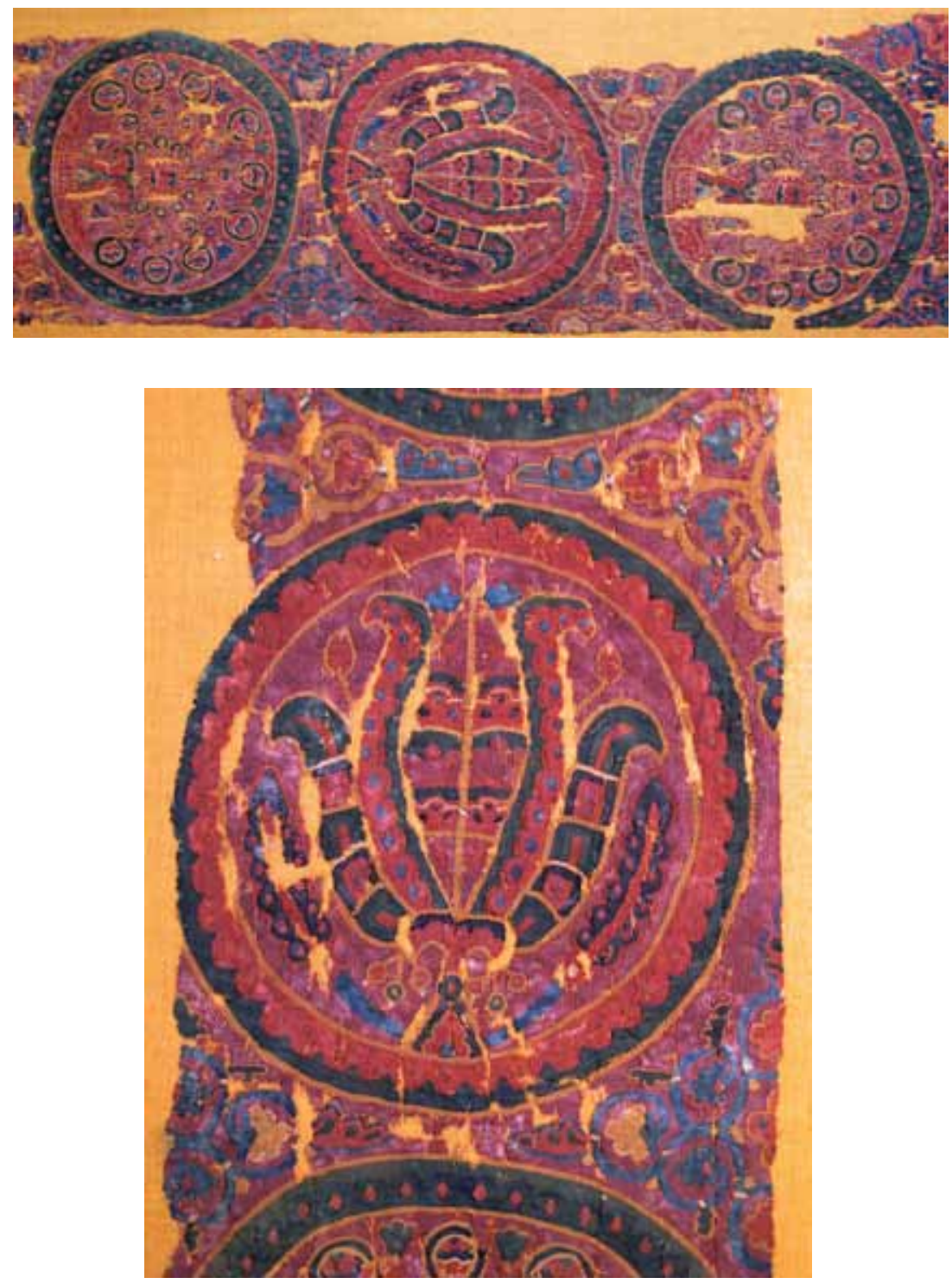

Ill. $52 / 53$ - Fragments of textile from some royal workshop from the end of the rule of Umayyad and the beginning of the Abbasid dynasty, from the middle or the second half of the 8th century, found in the Baroque reliquary of St. Anastasius. 


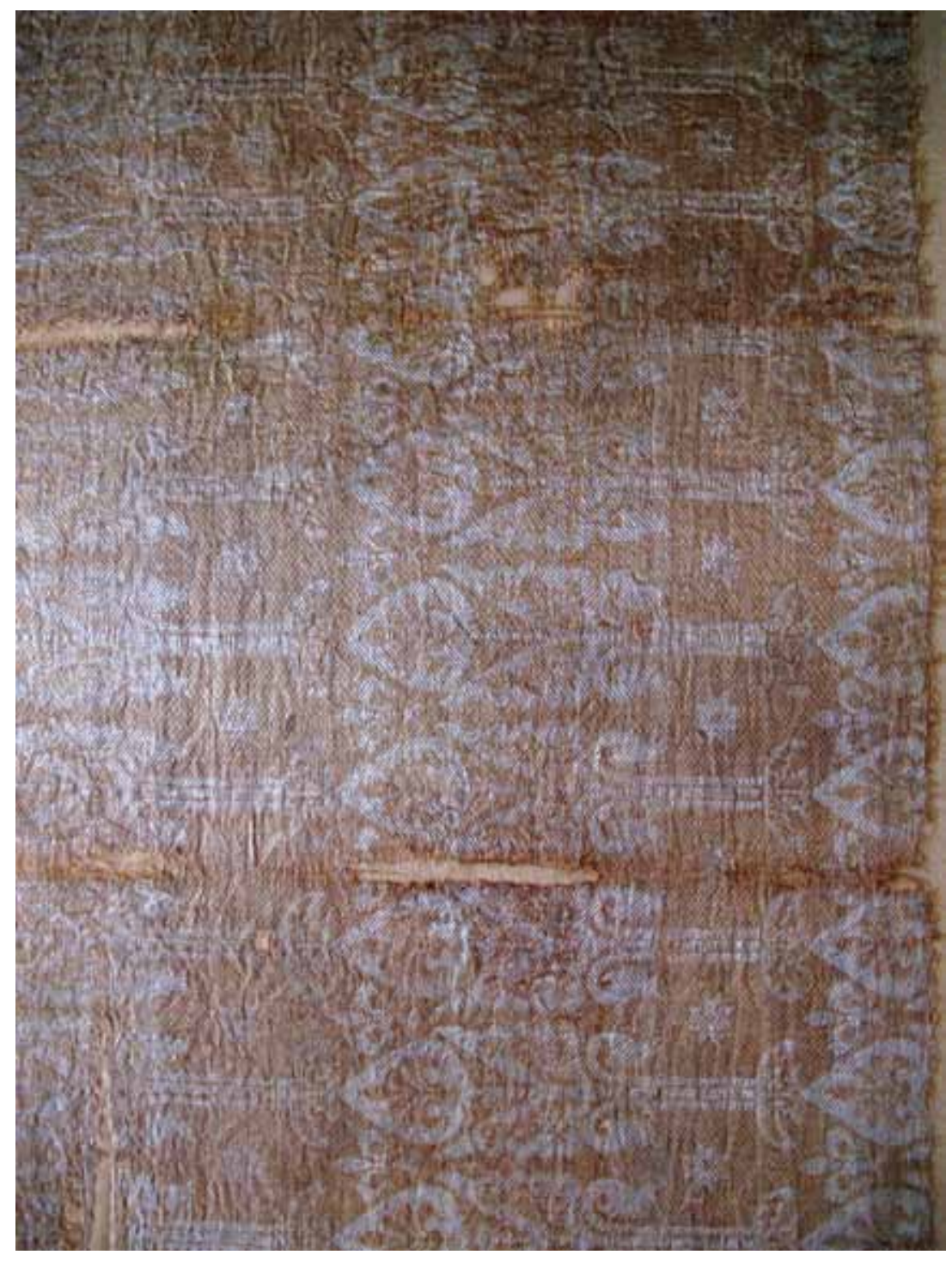

Ill. 54 - Textile fragments of the $\mathrm{I} 200 \mathrm{~s}$, found in the Baroque reliquary of St. Anastasius. 


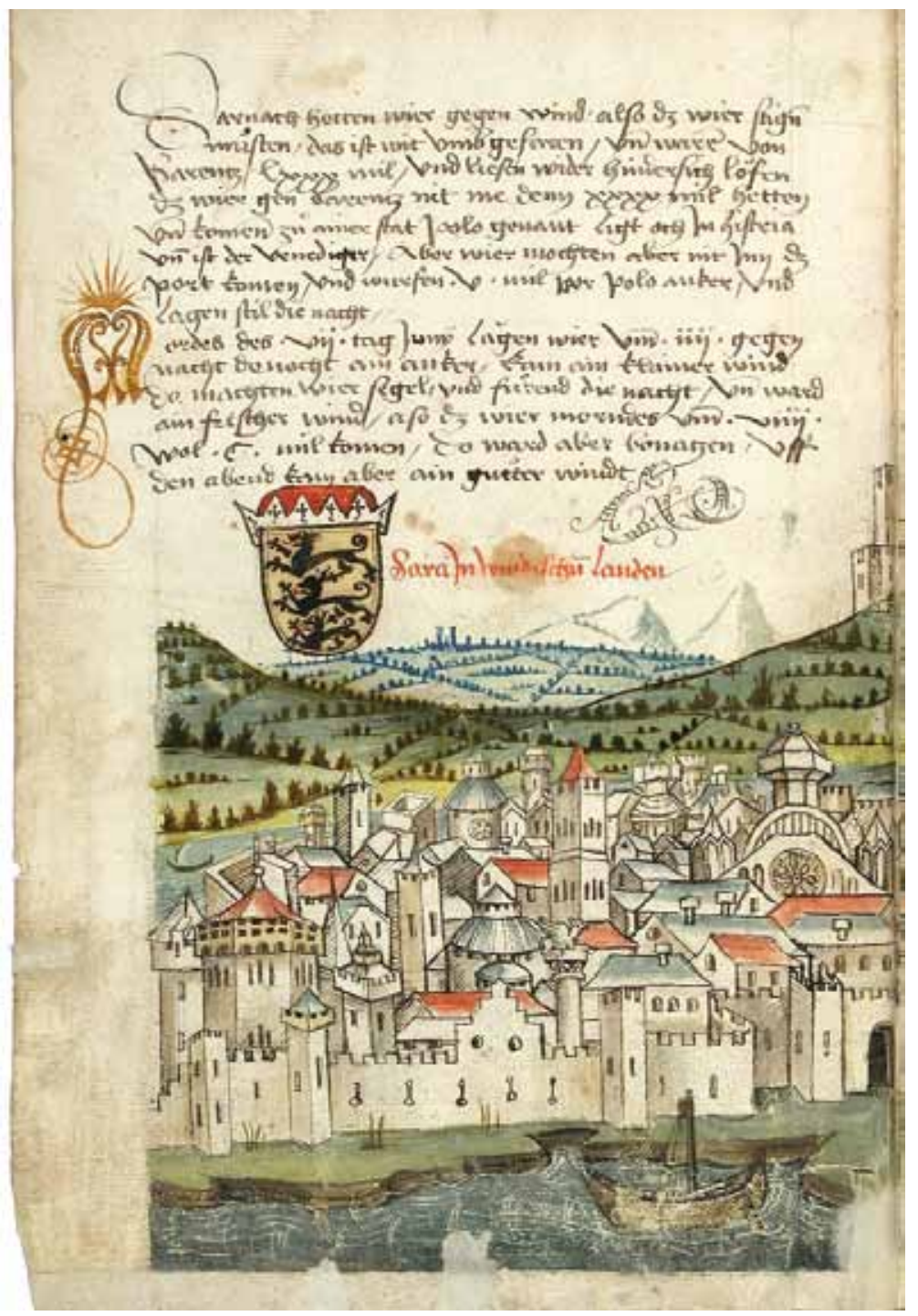

Ill. 55 - View from Zadar, in: Karlsruhe, Badische Landesbibliothek, Cod. St. Peter, pap. 32. Manuscript, Lake Constance-Region (Konstanz?), around I 487 (Konrad von Grünenberg, Beschreibung der Reise von Konstanz nach Jerusalem). 


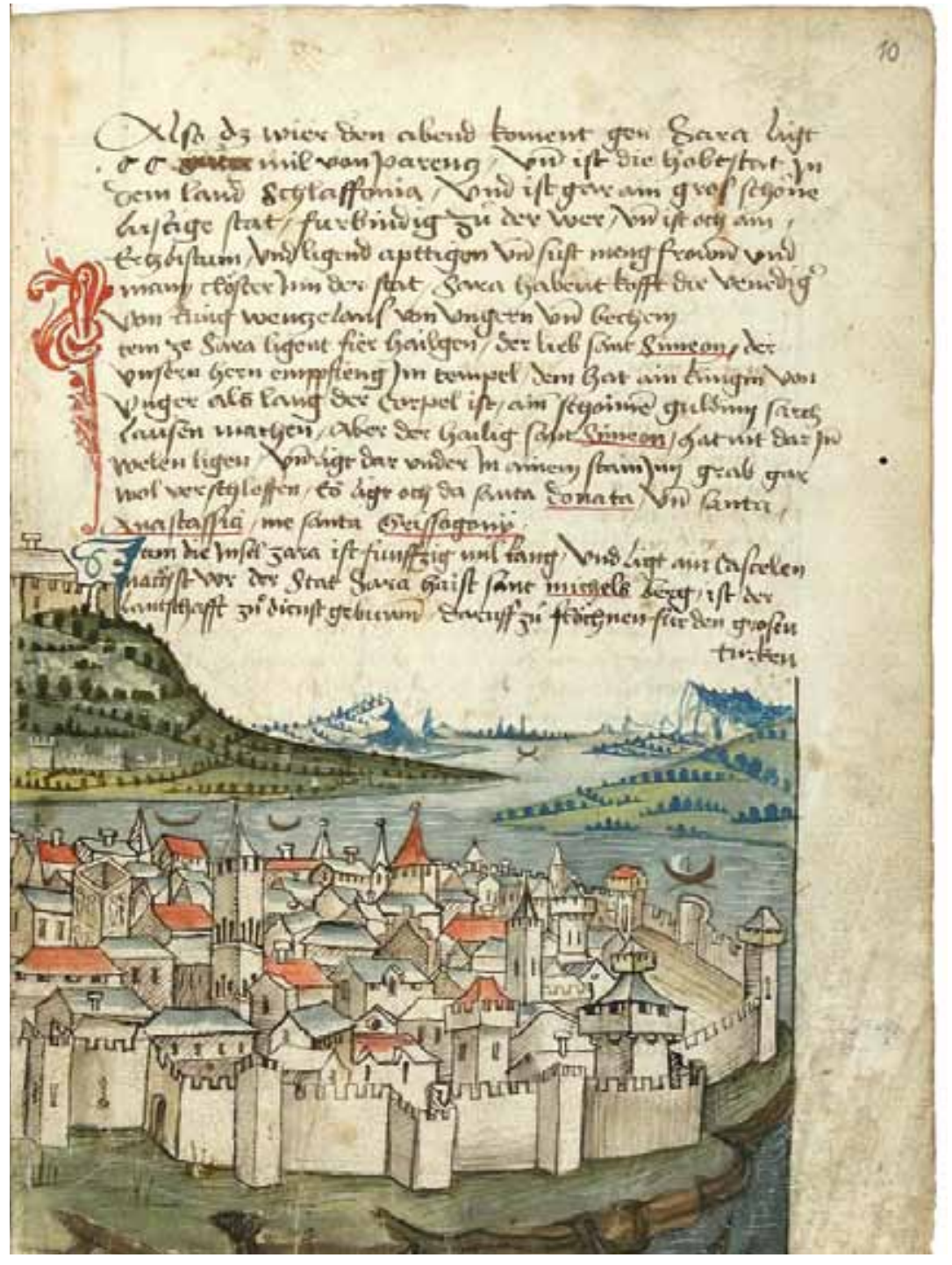

Ill. 56 - View from Zadar, in: Karlsruhe, Badische Landesbibliothek, Cod. St. Peter, pap. 32. Manuscript, Lake of Constance-Region (Konstanz?), around I 487 (Konrad von Grünenberg, Beschreibung der Reise von Konstanz nach Jerusalem). 


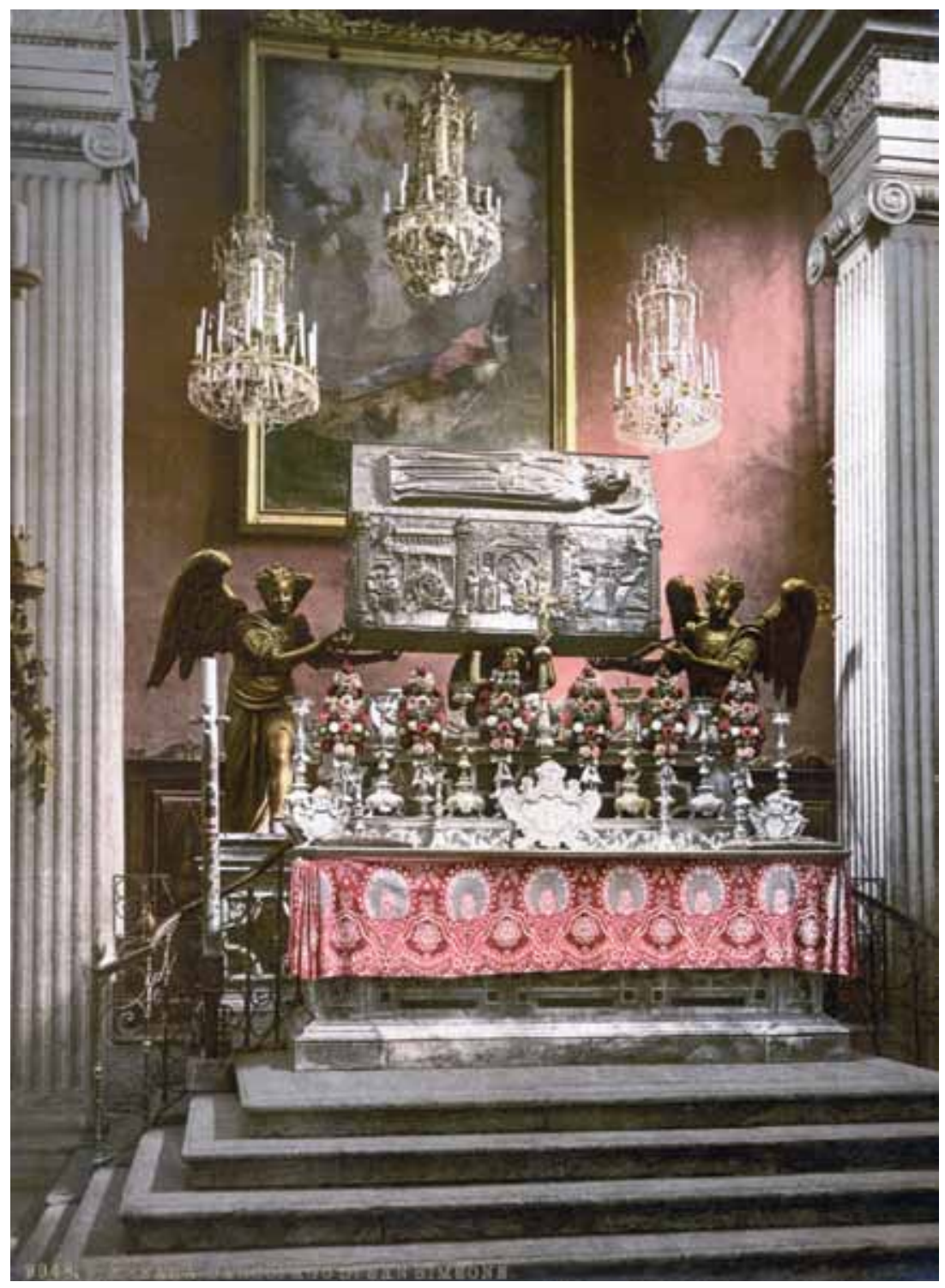

Ill. 57 -Zadar, the Chest of St. Simeon, color photo lithograph, c. I 800, (Library of congress, Prints and Photographs Division). 


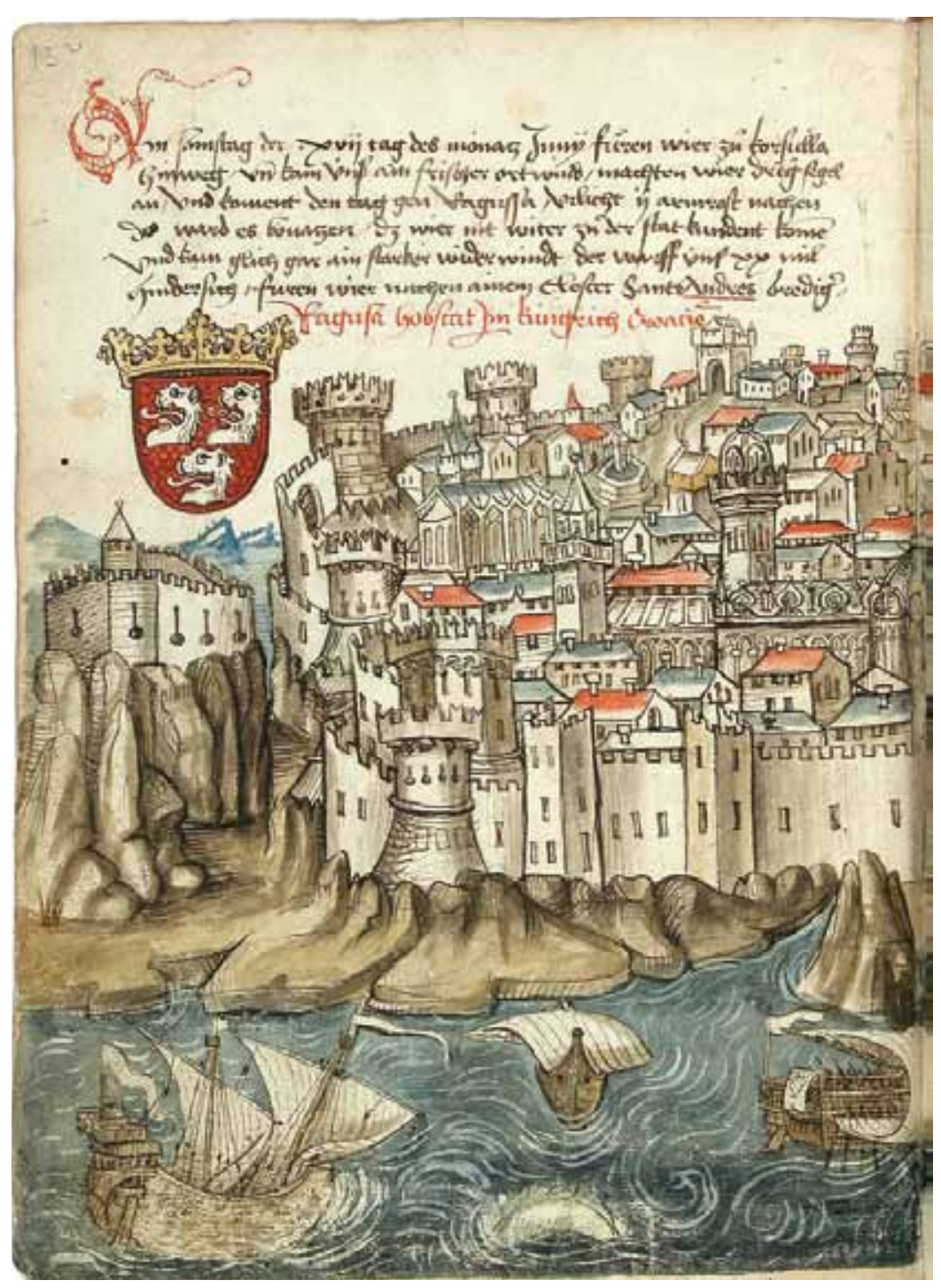

Ill. 58 - View from Dubrovnik, in: Karlsruhe, Badische Landesbibliothek, Cod. St Peter, pap. 32. Manuscript, Lake of Constance-Region (Konstanz ?), around $\mathrm{I}_{4} 87$ (Konrad von Grünenberg, Beschreibung der Reise von Konstanz nach Jerusalem). 


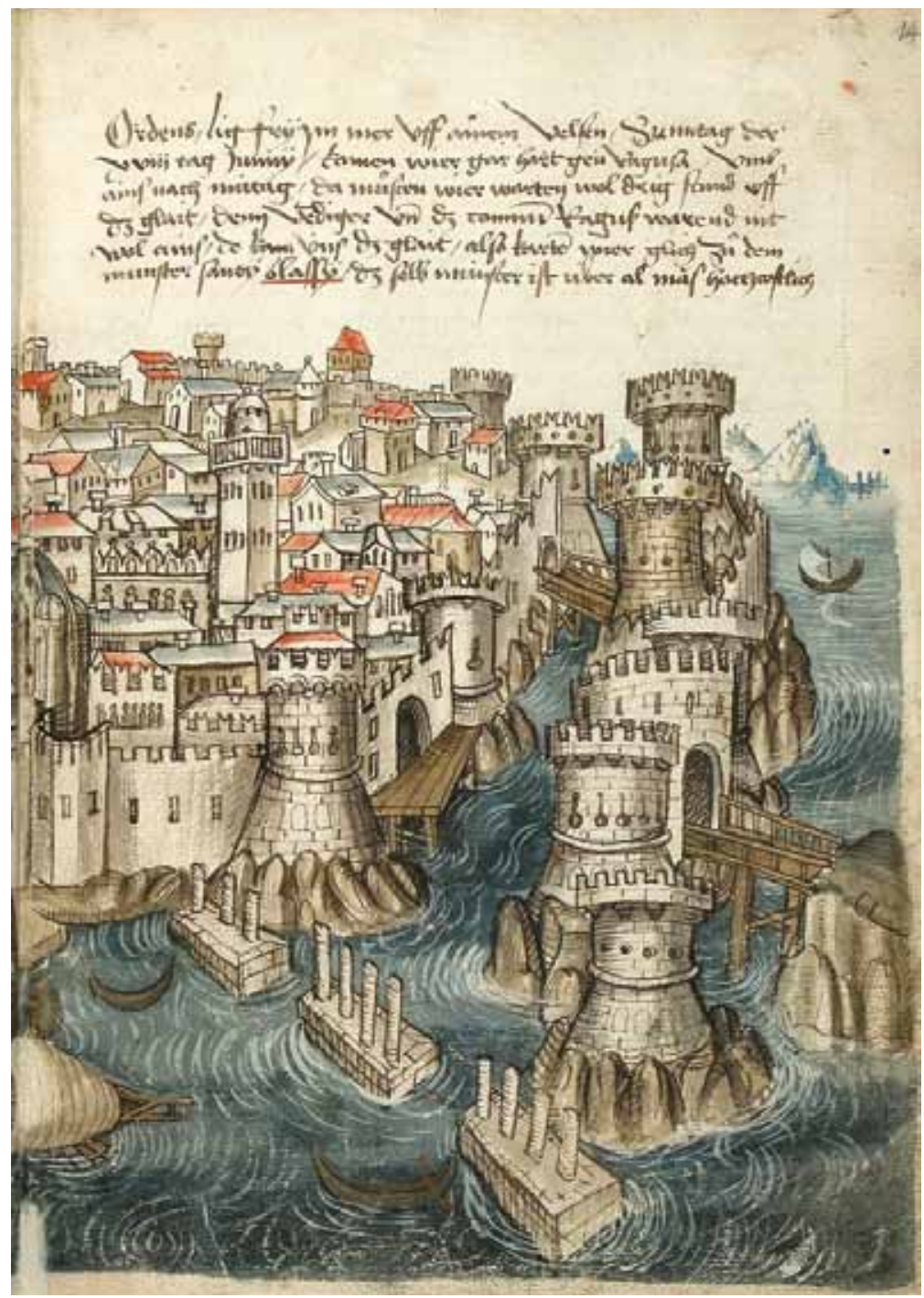

Ill. 59 - View from Dubrovnik, in: Karlsruhe, Badische Landesbibliothek, Cod. St Peter, pap. 32. Manuscript, Lake of Constance-Region (Konstanz ?), around $\mathrm{I}_{4} 87$ (Konrad von Grünenberg, Beschreibung der Reise von Konstanz nach Jerusalem). 


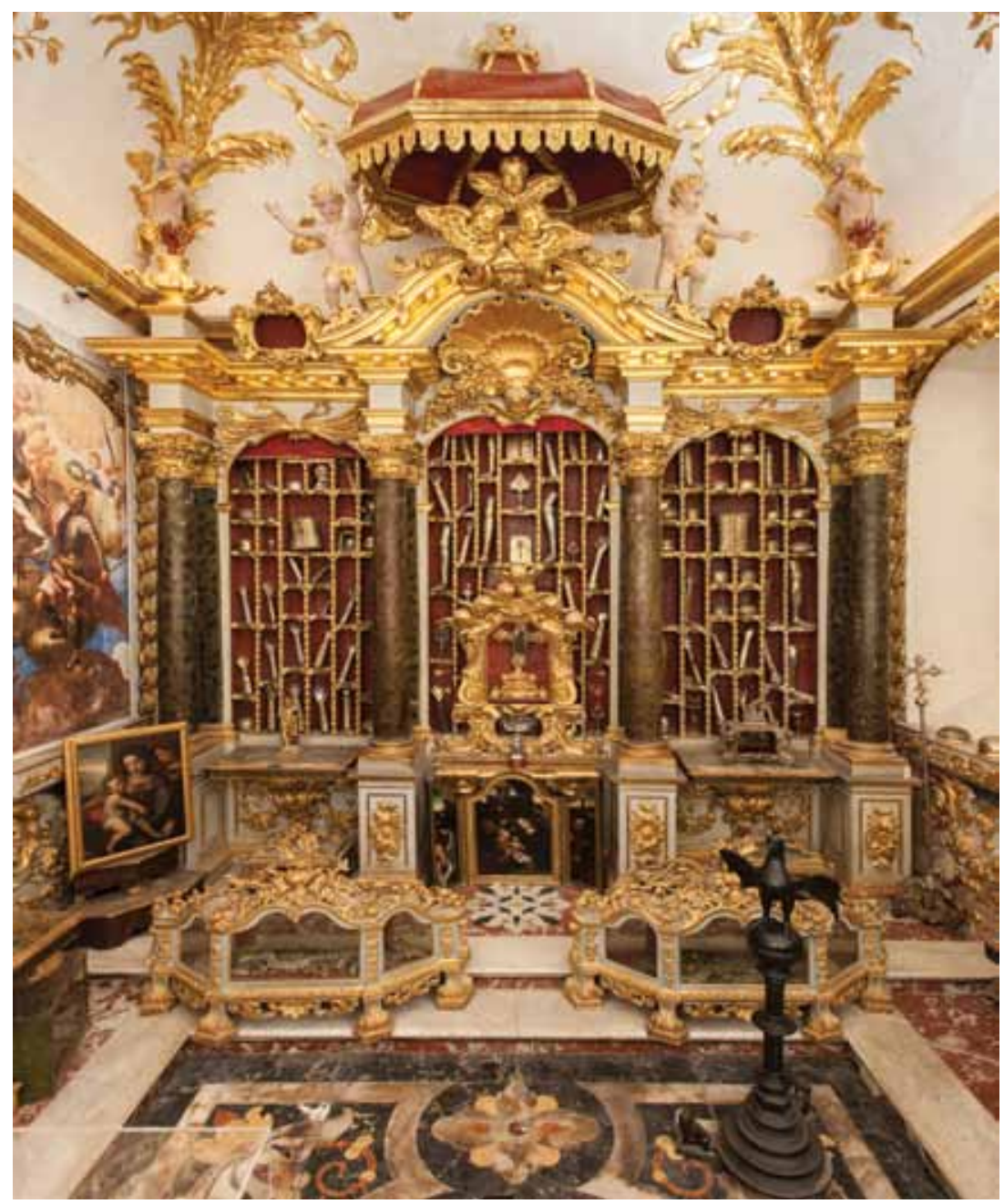

Ill. 60-Marino Gropelli (attr.), armoire for relics, between I7I 3 and I7I 7 . 


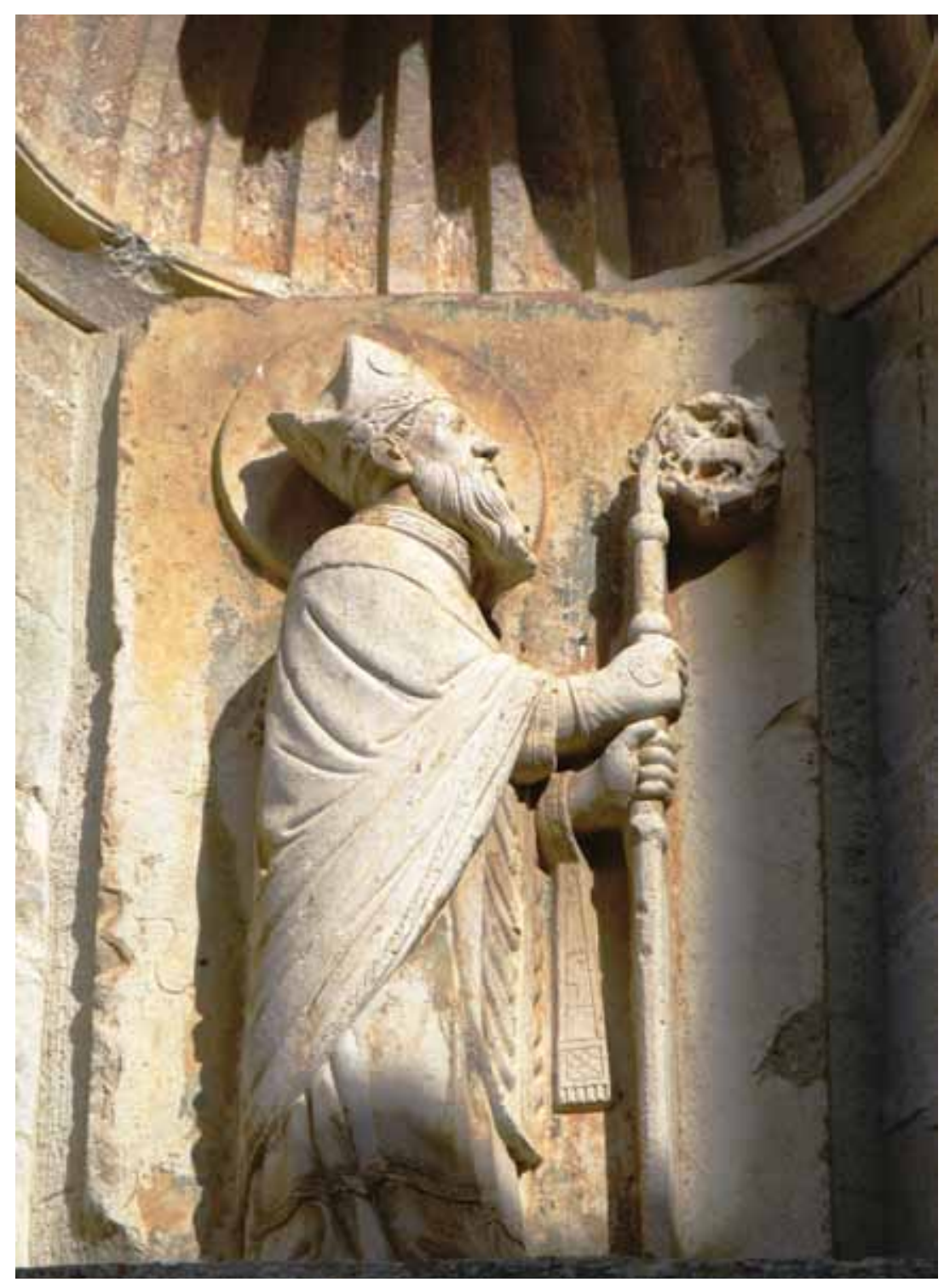

Ill. 6r - St. Blaise (c. I490), once at the City hall. 


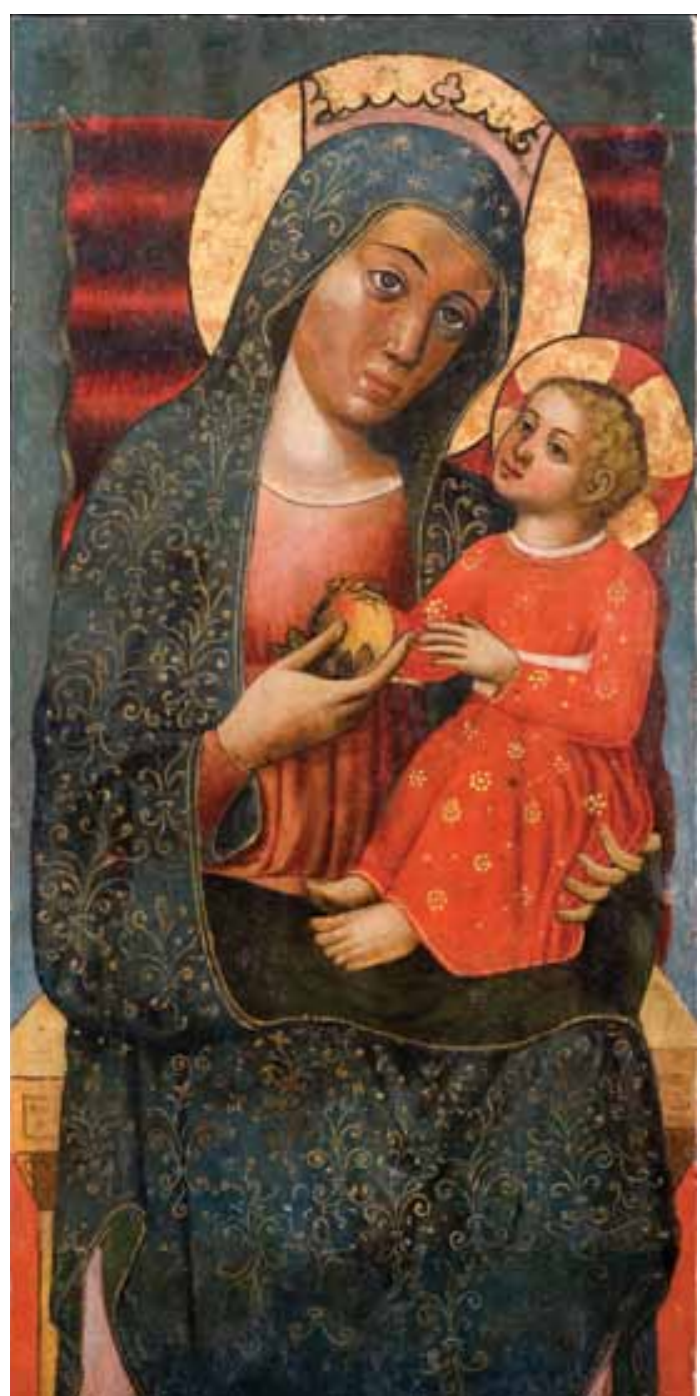

Ill. 62 - Our Lady of Porat, unknown Dubrovnik painter of i 5 th century (above earlier layer of the i 4 th century), Dubrovnik cathedral, the altar of Our Lady of Porat. 


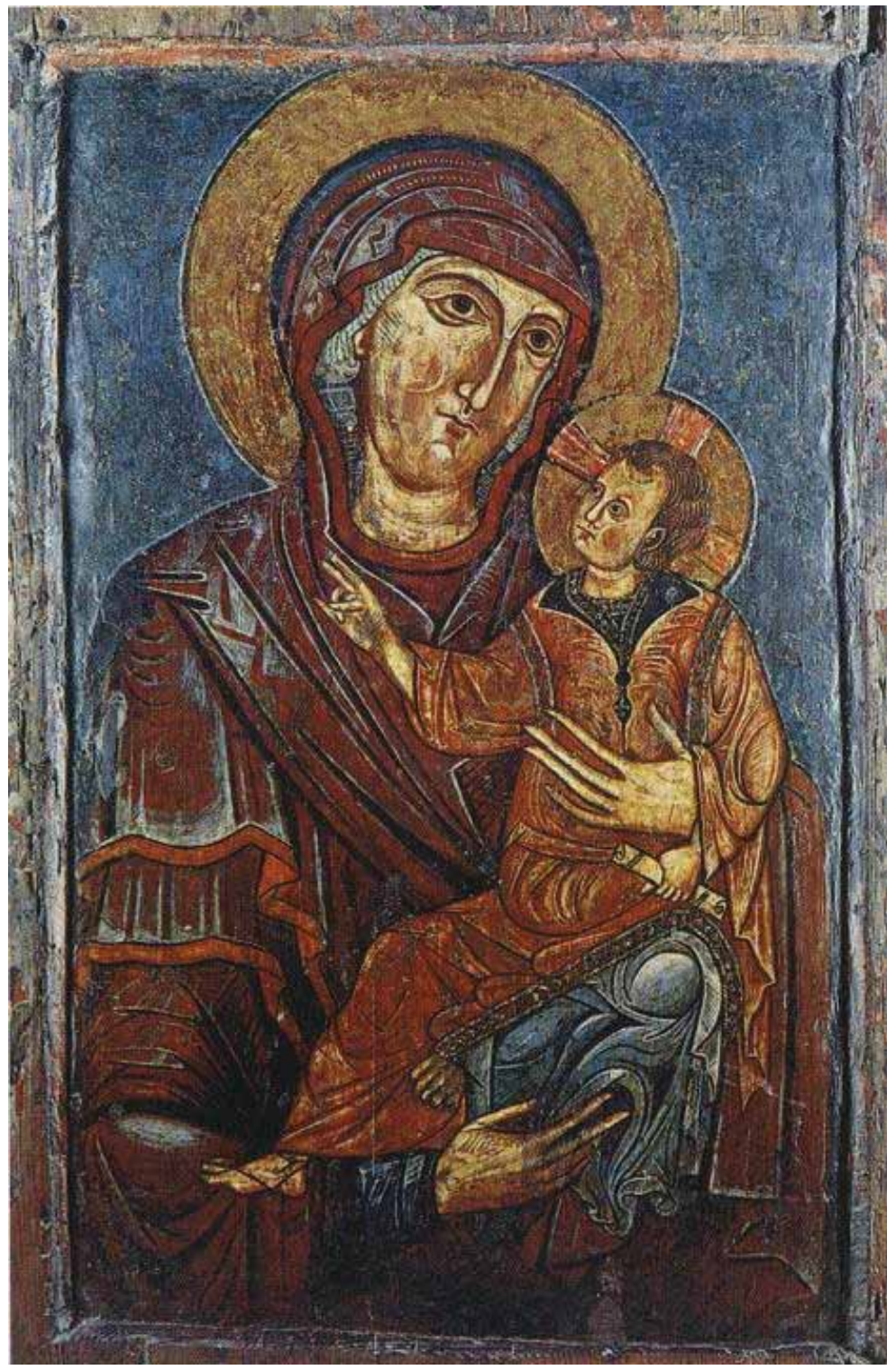

Ill. 63 - Our Lady of Carmel (earlier Sta. Maria de Buci, from island of Biševo), c. I 280, Hvar cathedral, on altar in the chapel of Hektorović family. 


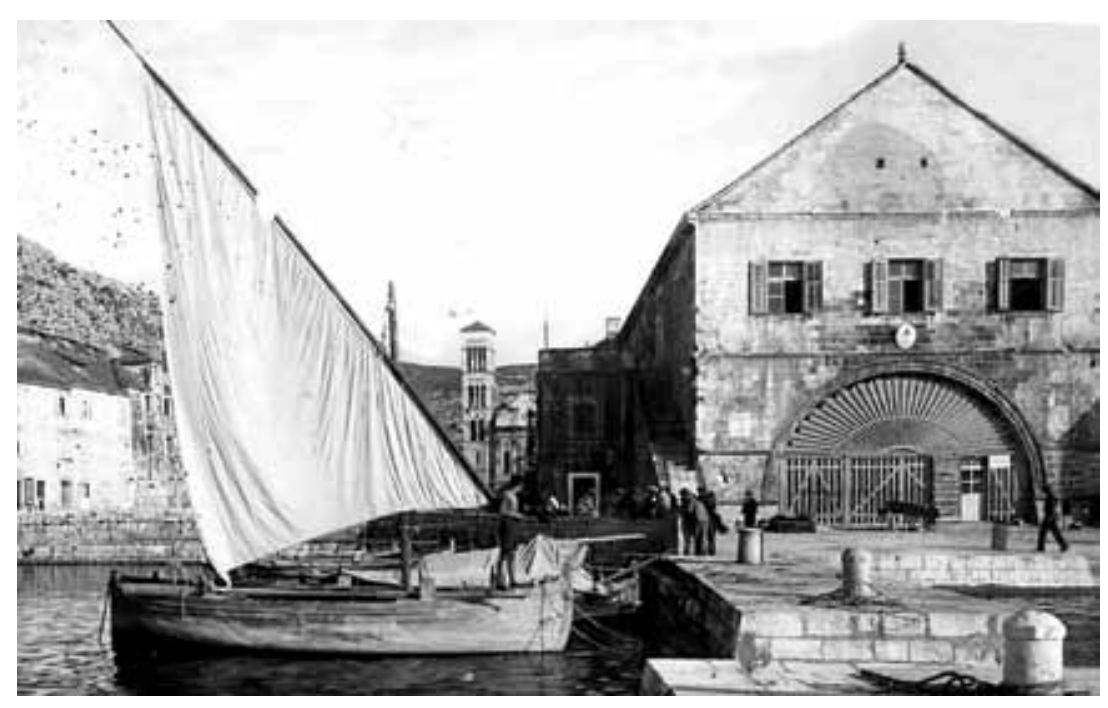

Ill. 64 - Hvar, Renaissance Arsenal.

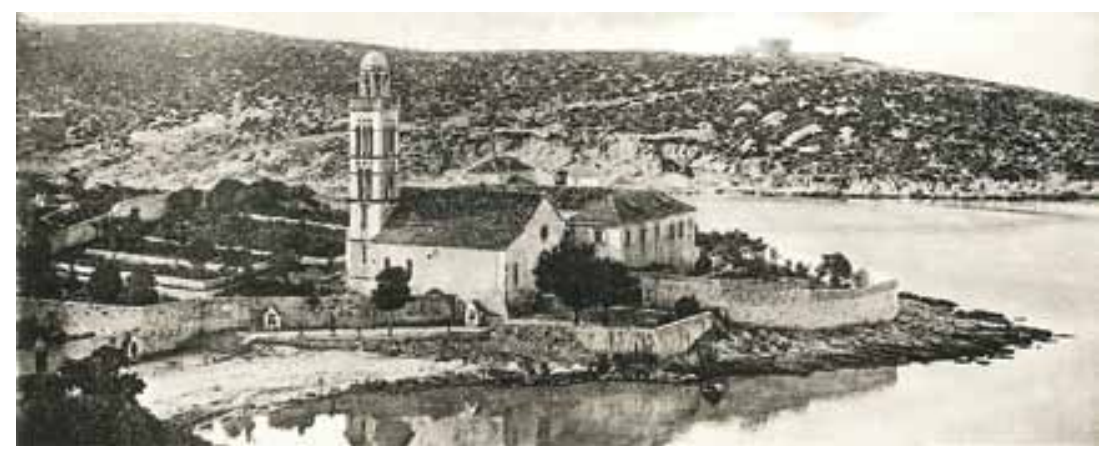

Ill. 65 - Ćiril Metod Iveković (I9I 2), Franciscan monastery of Our Lady of Mercy. 


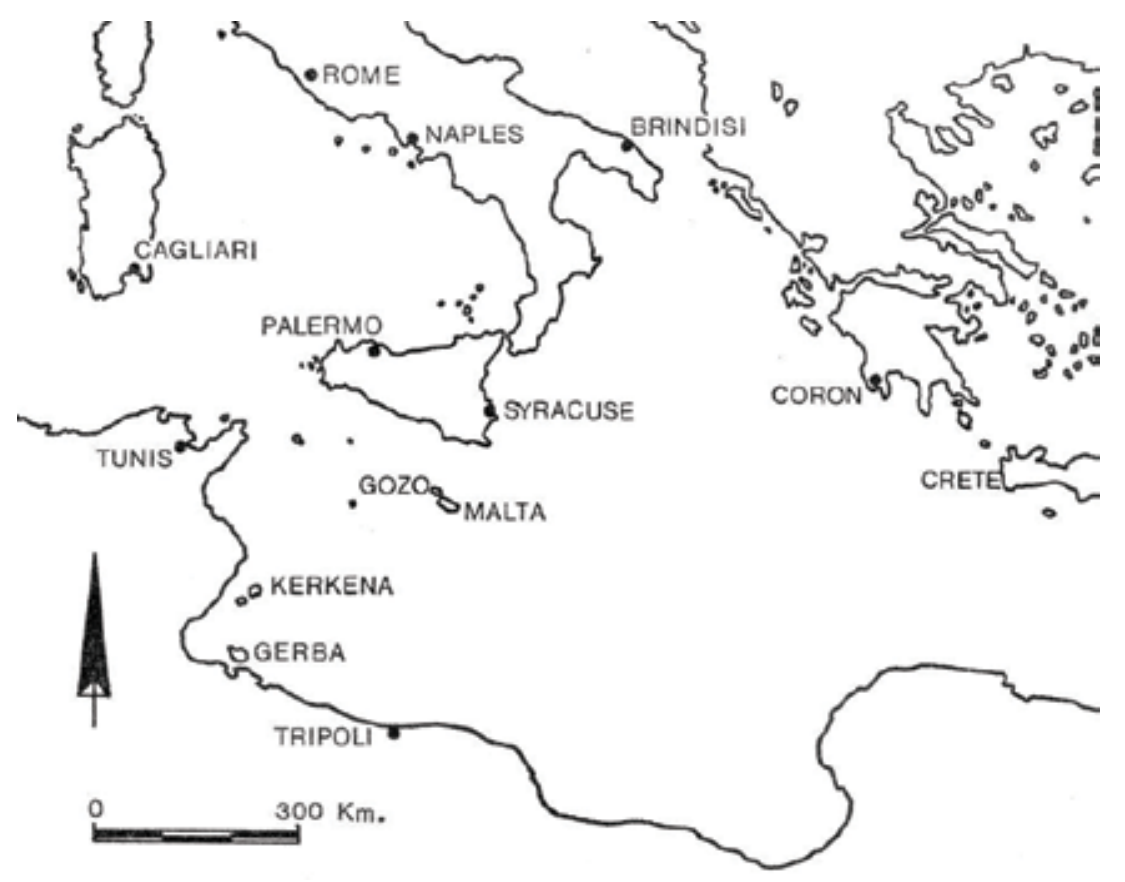

Ill. 66 - Map of the Central Mediterranean showing the geographic location of the Islands of Malta. 


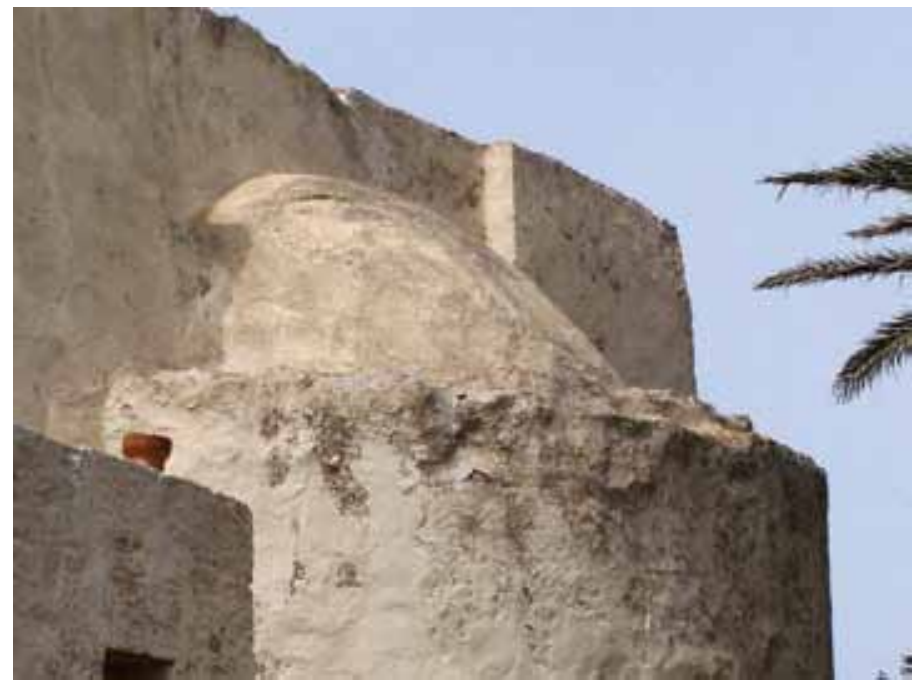

Ill. 67-Rock of Comino, church of Santa Maria mentioned in 'Il Compasso da Navigare', siculo-byzantinesque apse (Photo credit: Keith Buhagiar).

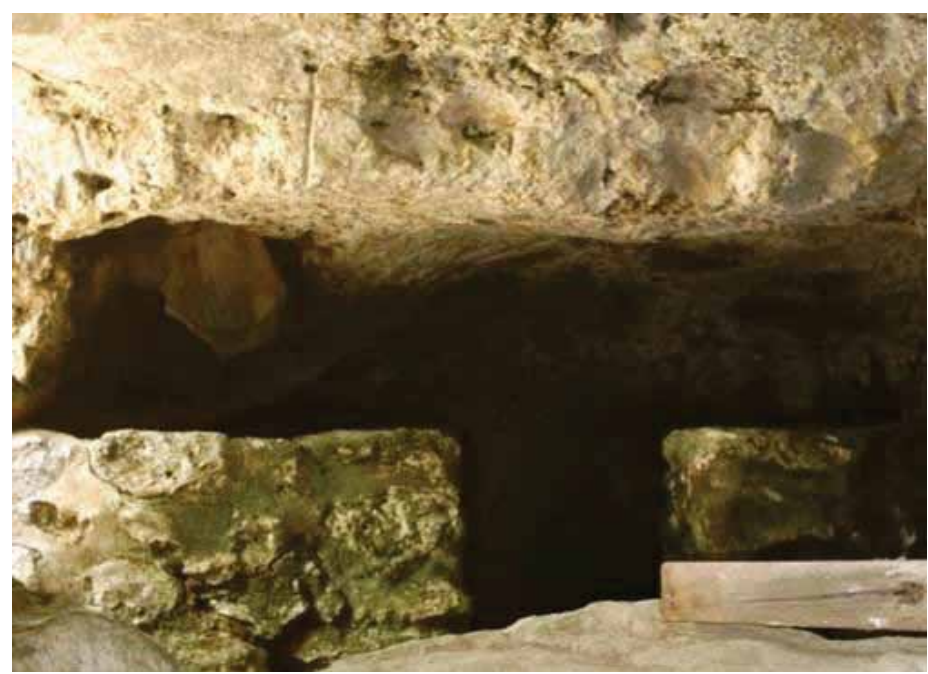

Ill. 68 - Rock of Comino, church of Santa Maria, probable anchorite's cavecell in the close neighbourhood (Photo credit: Keith Buhagiar). 


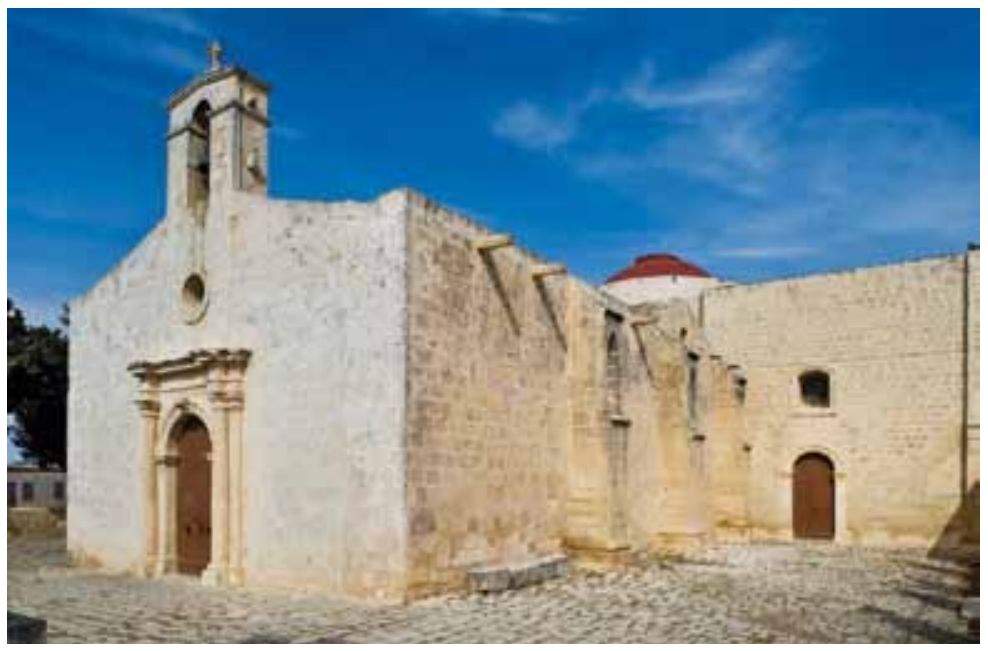

Ill. 69 - Zejtun, church of Santa Caterina structurally modified in the sixteenth and seventeenth centuries (Photo credit: Joseph P. Borg).

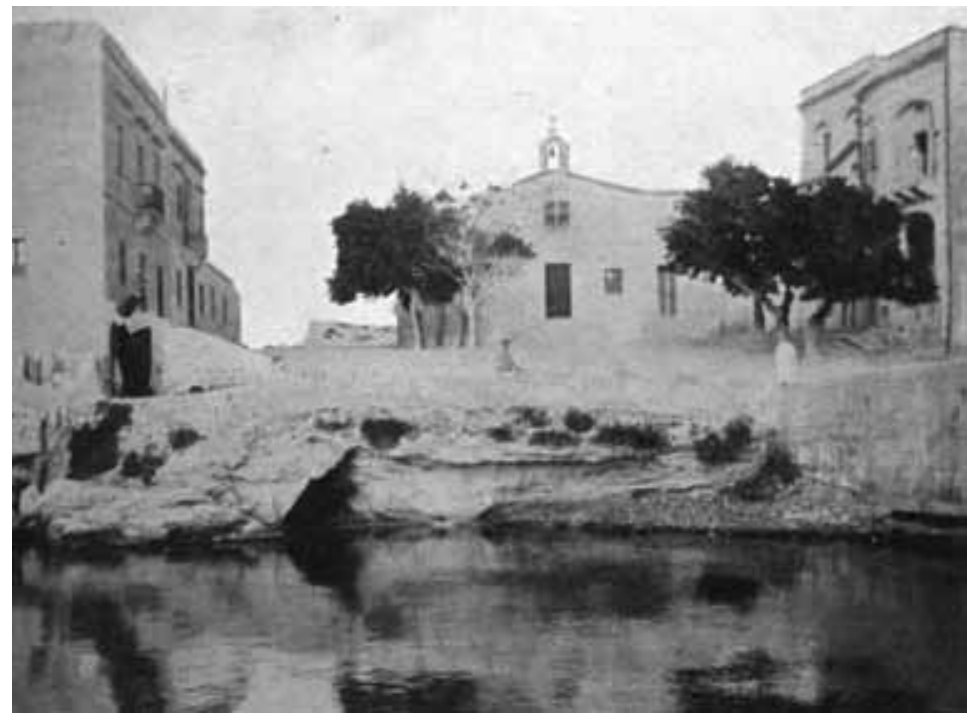

Ill. 70-St. Paul's Bay, old photograph (ca. I9I4) of the church as re-founded by Grand Master Alof de Wigncourt in I616. The church was badly damaged in the blitz of the Second World War and re-built. 


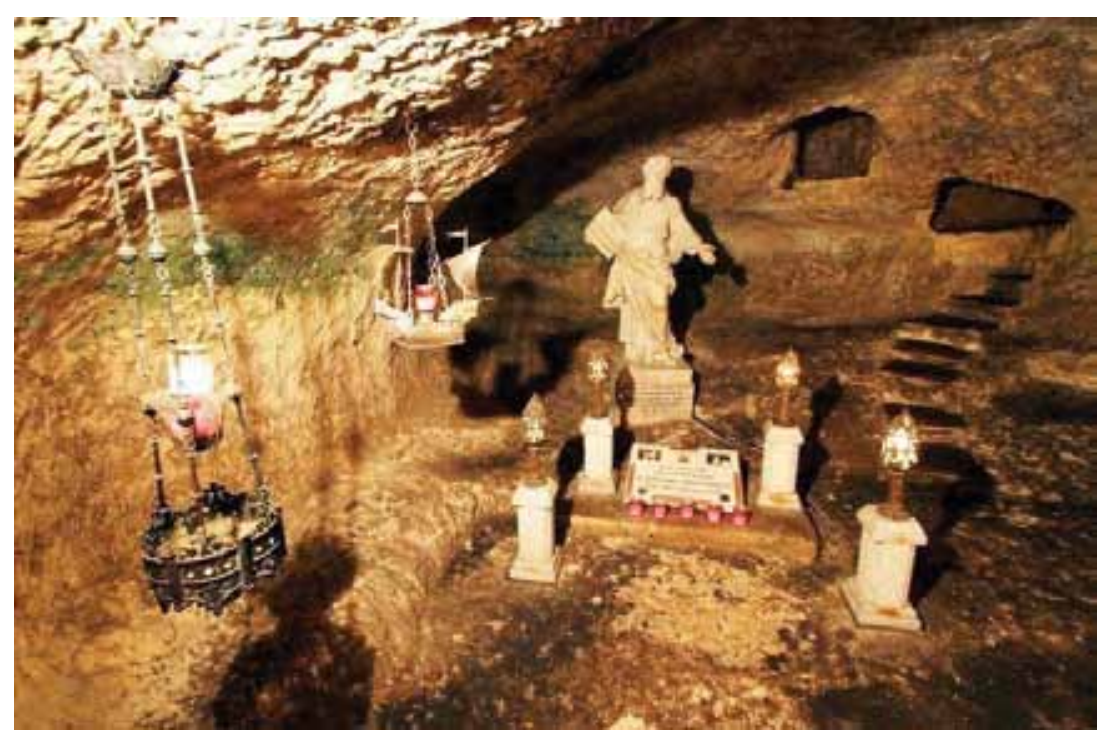

Ill. 7I - Rabat, the man-made cave in the ditch of the Roman city of Melite which, according to legend, was St Paul's home during his stay in Malta. 


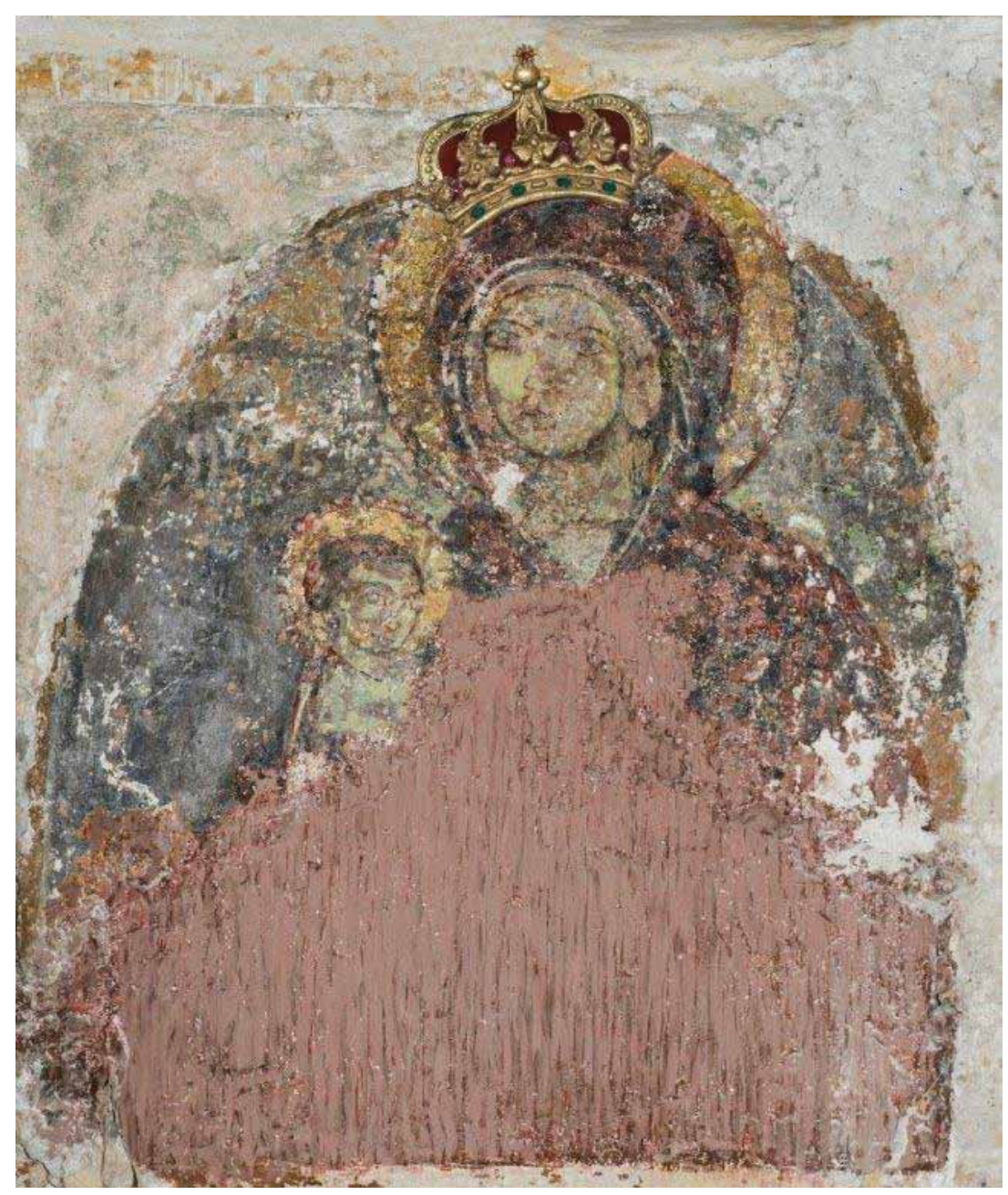

Ill. 72 - Mellieha, Rock-cut sanctuary of the Nativity of the Virgin, siculobyzantinesque icon of the Virgin and Child. 


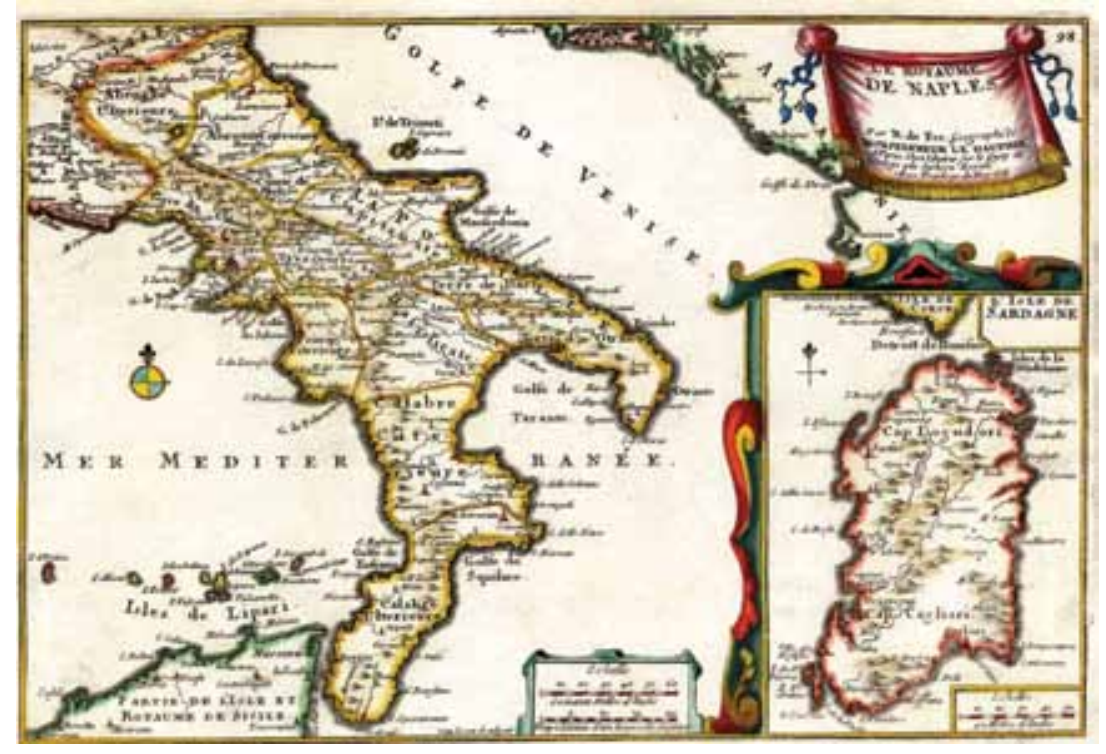

Ill. 73 - Carta dell'Italia meridionale, incisione in rame colorata, da Nicolas de Fer, Les Royaume de Naples et de Sicile, Paris 1705. 


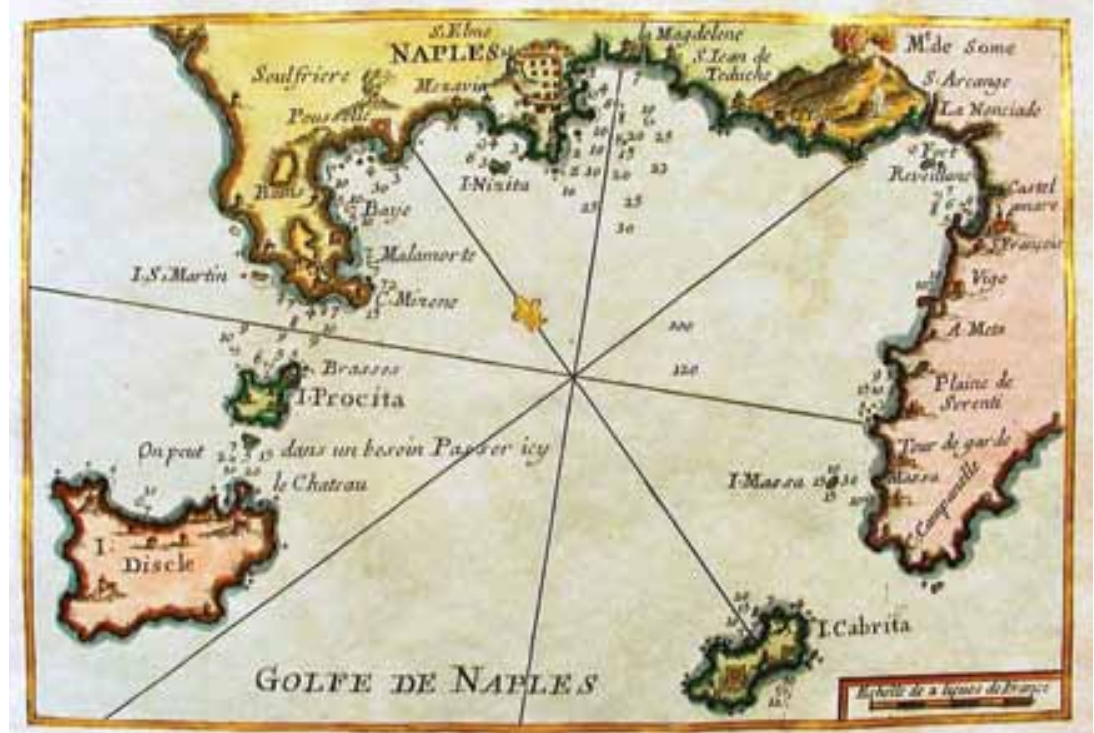

Ill. 74 - Il golfo di Napoli, incisione in rame colorata, da Joseph Roux, Recueil des principaux plans des ports et rades de la Mer Méditerranée, Marseille 1764 . 


\section{Illustrations Lucherini}

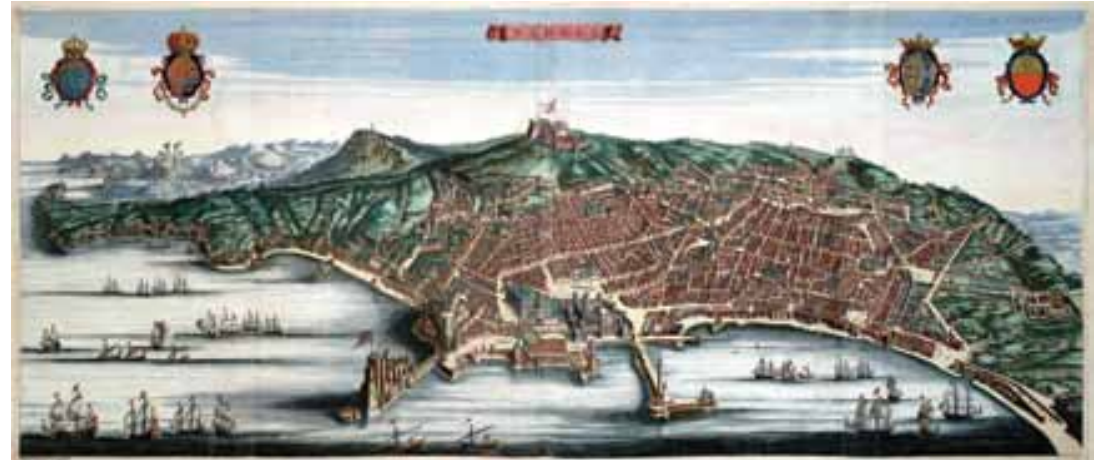

Ill. 75 - Matthäus Seutter, Neapolis, Augsburg I730, incisione in rame colorata.

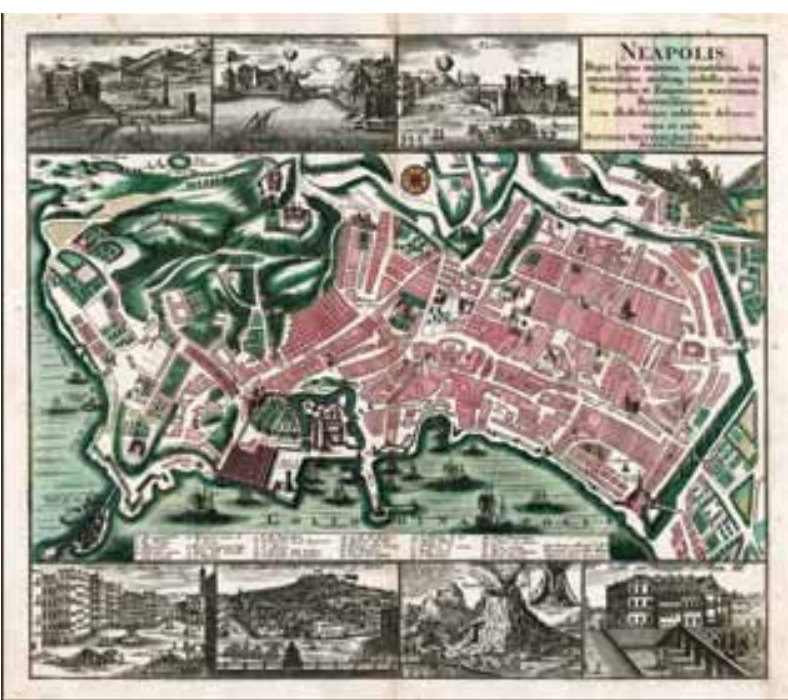

Ill. 76 - Bastiaen Stoopendaal (inc.), Veduta di Napoli a volo d'uccello, in Pierre Mortier, Nouveau theatre d'Italie, Amsterdam I 704, incisione in rame colorata. 


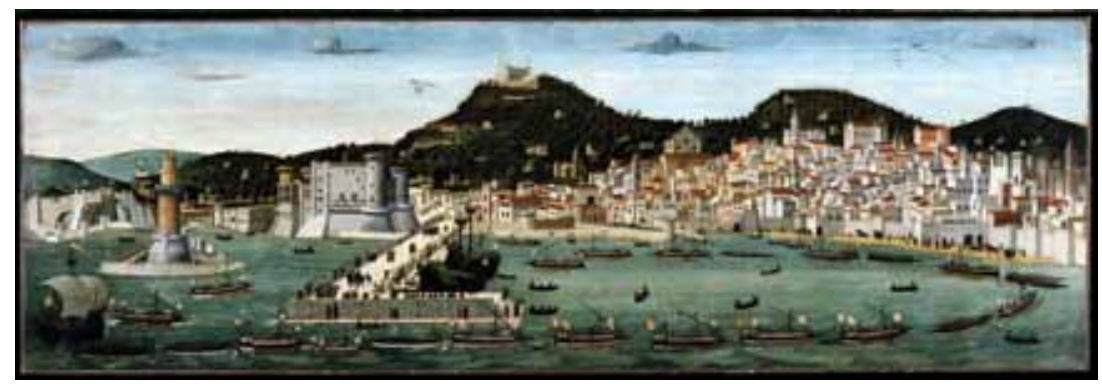

Ill. 77 - Tavola Strozzi, olio su legno, ca. 1465 , Napoli, Museo di San Martino.

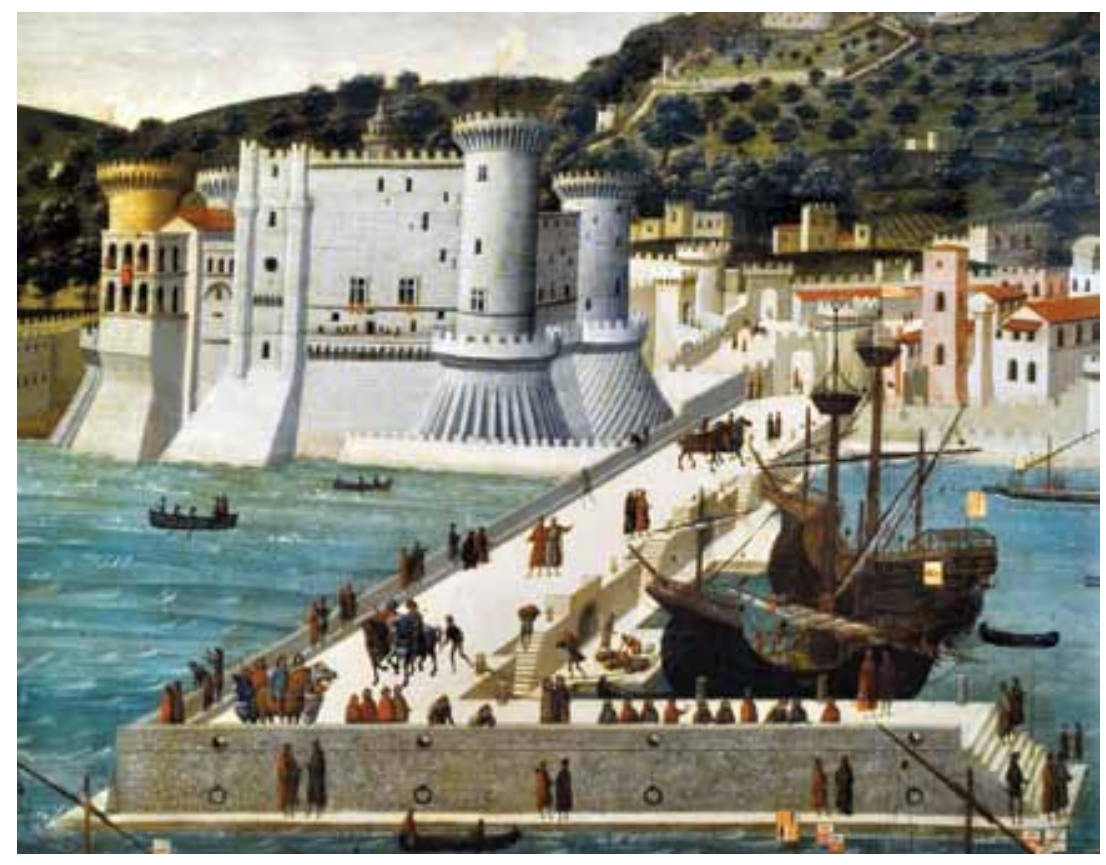

Ill. 78 - Tavola Strozzi, olio su legno, ca. 1465 , Napoli, Museo di San Martino, part. con il molo e Castel Nuovo. 


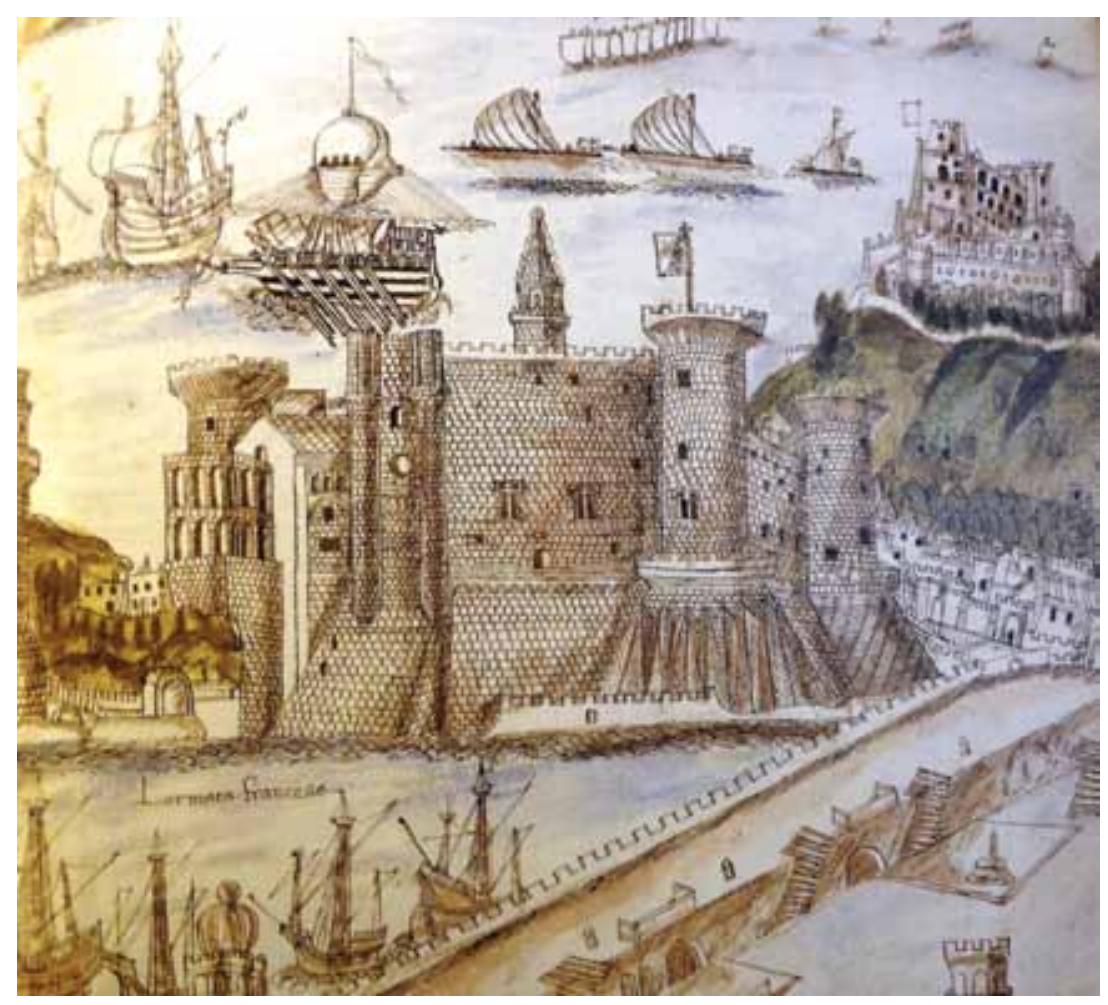

Ill. 79 - Veduta del porto di Napoli, disegno a piuma, ca. I498, in: New York, Pierpont Morgan Library, Ms. M. 801, fol. I I6v-I 7 . 


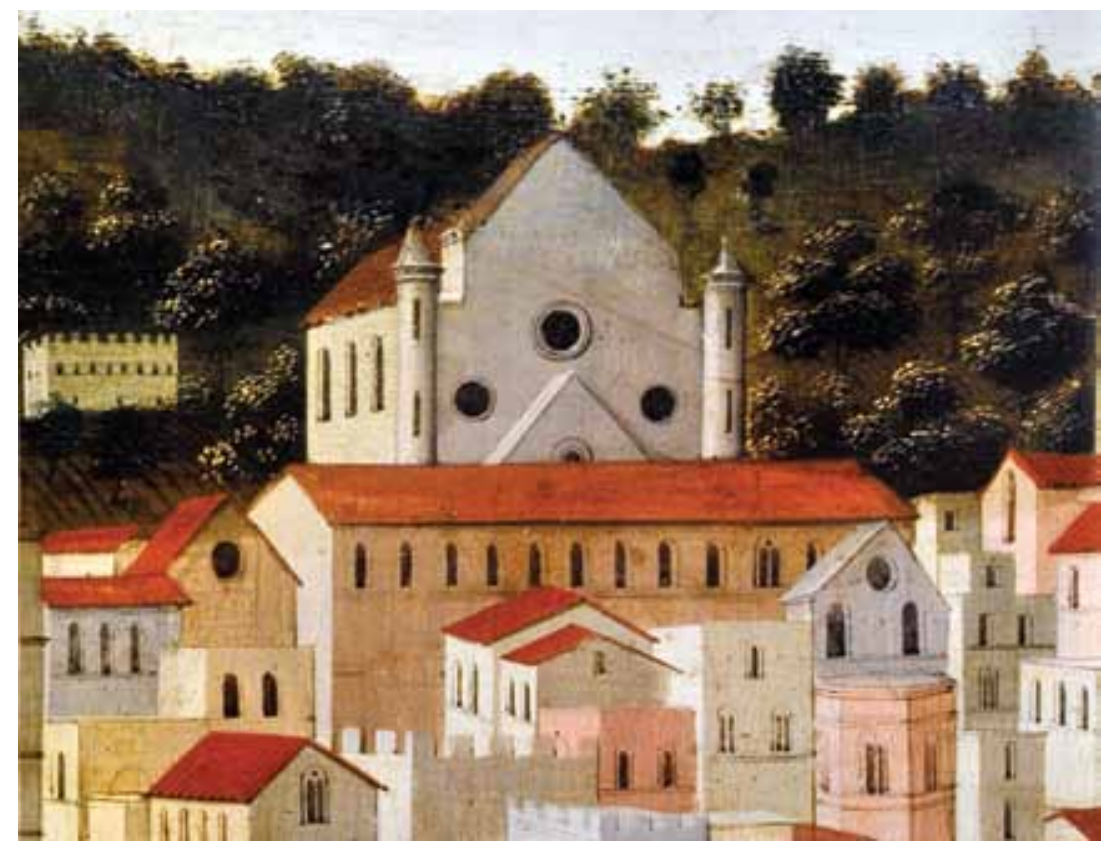

Ill. 80 - Tavola Strozzi, olio su legno, ca. I465, Napoli, Museo di San Martino, part. con la chiesa di Santa Chiara. 


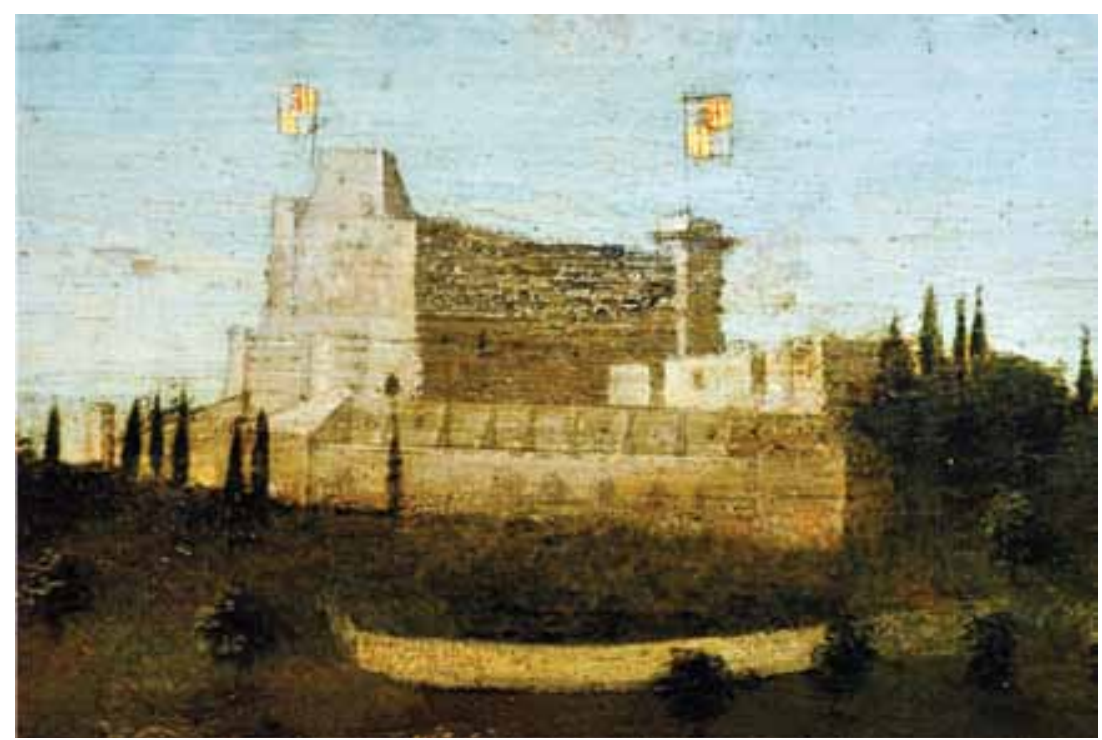

Ill. 8 I - Tavola Strozzi, olio su legno, ca. I465, Napoli, Museo di San Martino, part. con la certosa di San Martino e il Belforte. 


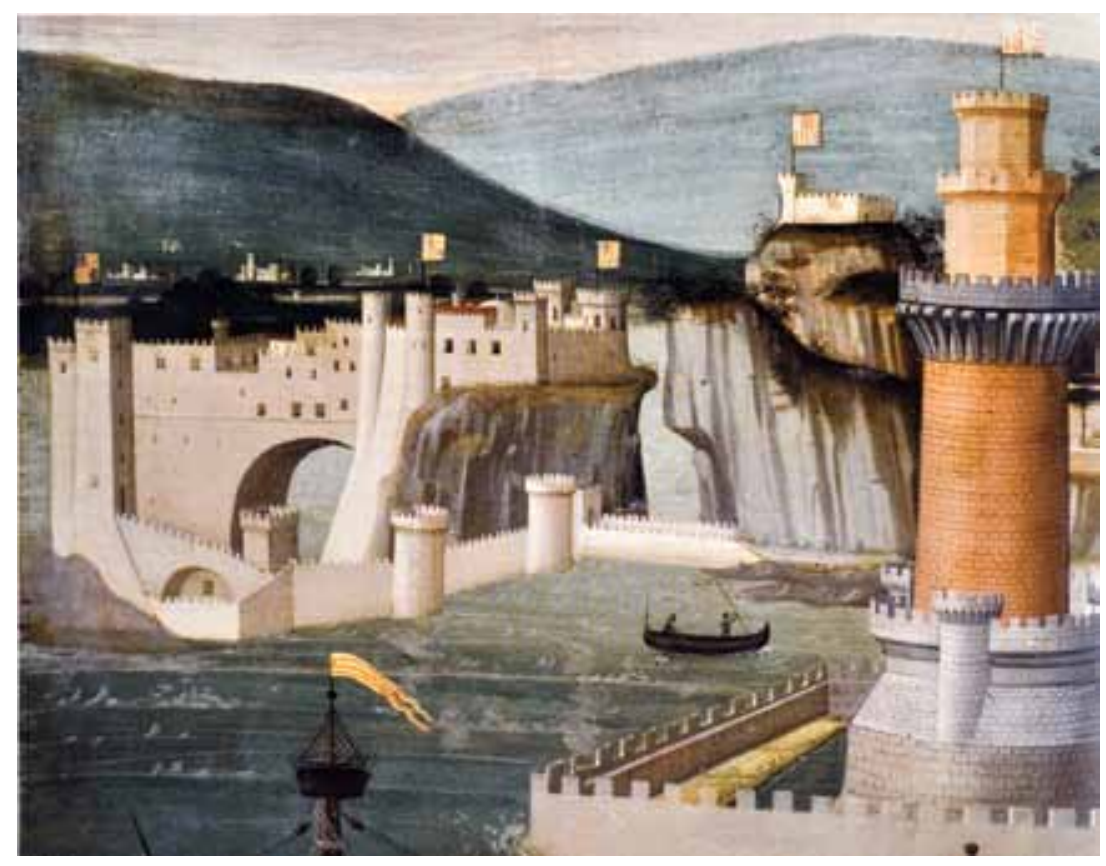

Ill. 82 - Tavola Strozzi, olio su legno, ca. I465, Napoli, Museo di San Martino, part. con il Castel dell'Ovo. 


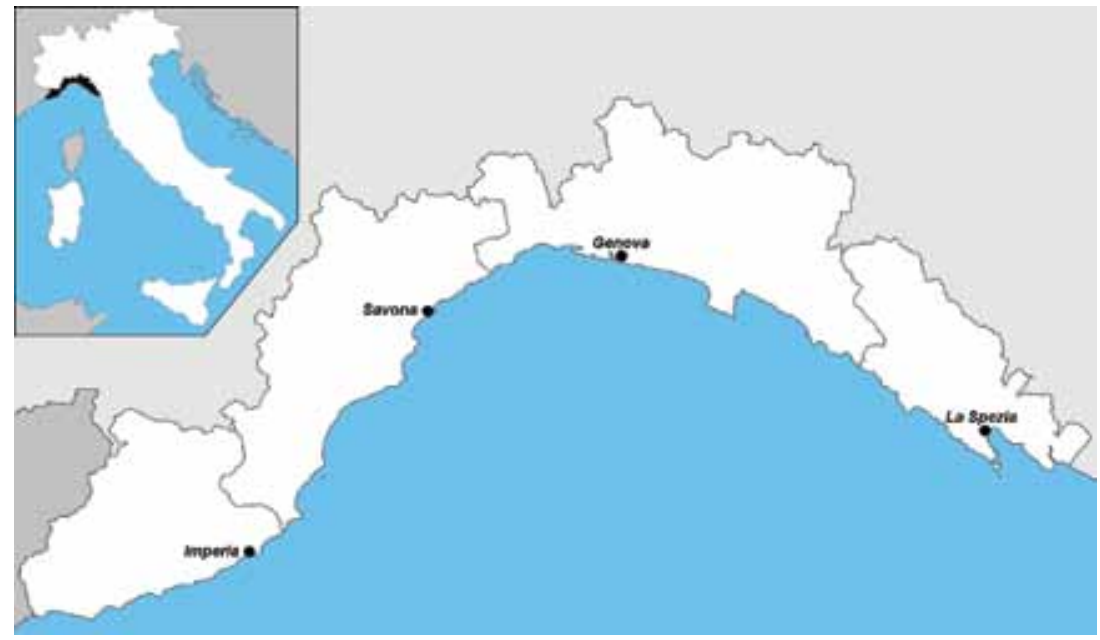

Ill. 83 - Situazione attuale: regione Liguria e relative città capoluogo di provincia.

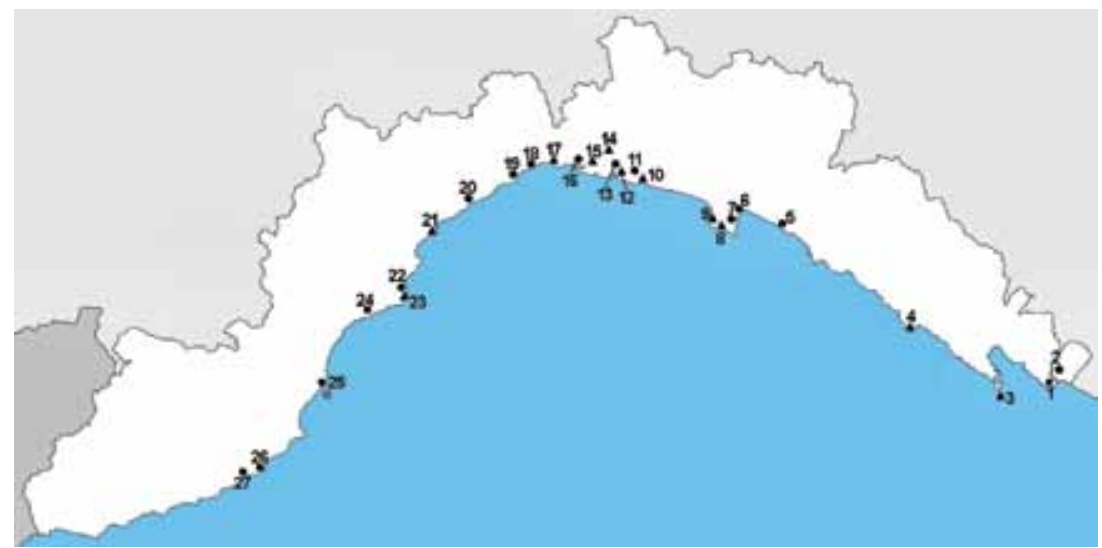

Ill. 84 - Postazioni comuni ai mss. ligure e magliabecchiano ( $\mathbf{\Delta})$, inoltre indicate solo nel ligure $(\bullet)$ e indicata solo nel magliabecchiano $(\mathbf{\bullet})$. 
I) S. Croce del Corvo (-)

2) S. Francesco de Ansiza, Sarzana? (•)

3) S. Venerio del Tino ( $\mathbf{\Delta})$

4) S. Antonio del Mesco ( $(\boldsymbol{\Delta})$

5) S. Francesco, Chiavari $(\bullet)$

6) S. Michele di Pagana $(\bullet)$

7) S. Margherita de Piscina, Santa Margherita (•)

8) S. Fruttuoso di Capodimonte ( $\mathbf{\Lambda})$

9) S. Nicolò di Capodimonte ( $(\boldsymbol{\Delta})$

Io) S. Girolamo di Quarto ( $(\mathbf{\Delta})$

I I) S. Giuliano di Albaro (•)

I2) Ss. Siro e Lorenzo, Genova ( $\mathbf{\Delta})$

I3) S. Maria del Carmine, Genova (•)

I4) S. Maria del Garbo, Rivarolo (ム)

I5) S. Maria di Coronata ( 4 )

i6) S. Andrea, Erzelli (Sestri Ponente) (•)

I7) S. Ambrogio, Voltri ( $\mathbf{\Delta})$

I8) S. Pietro di Vesima (•)

I9) Ss. Nazaro e Celso, Arenzano (•)

20) La Gloriosa de lo Ermito, Varazze (•)

2 I) S. Maria di Castello, Savona ( $(\mathbf{\Delta})$

22) S. Paragorio, Noli $(\bullet)$

23) S. Margherita, Noli ( $\mathbf{\Delta})$

24) La Gloriosa di Pia, Finalpia (•)

25) S. Martino, Albenga (Isola Gallinaria e Albenga) (•)

26) S. Erasmo, Diano $(\bullet)$

27) S. Maurizio di Porto Maurizio, Imperia 


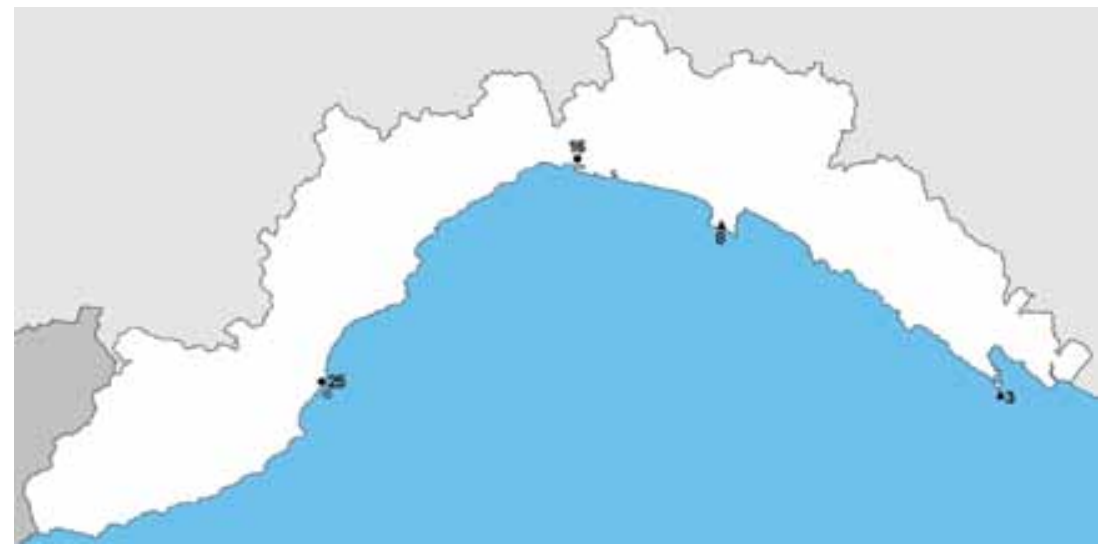

Ill. 85 - Ms. ligure: chiese monastiche di alta datazione: 3 ) S. Venerio del Tino

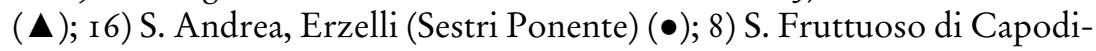
monte ( $\mathbf{\Lambda}) ; 25)$ S. Martino, Albenga (Isola Gallinaria e Albenga) $(\bullet)$.

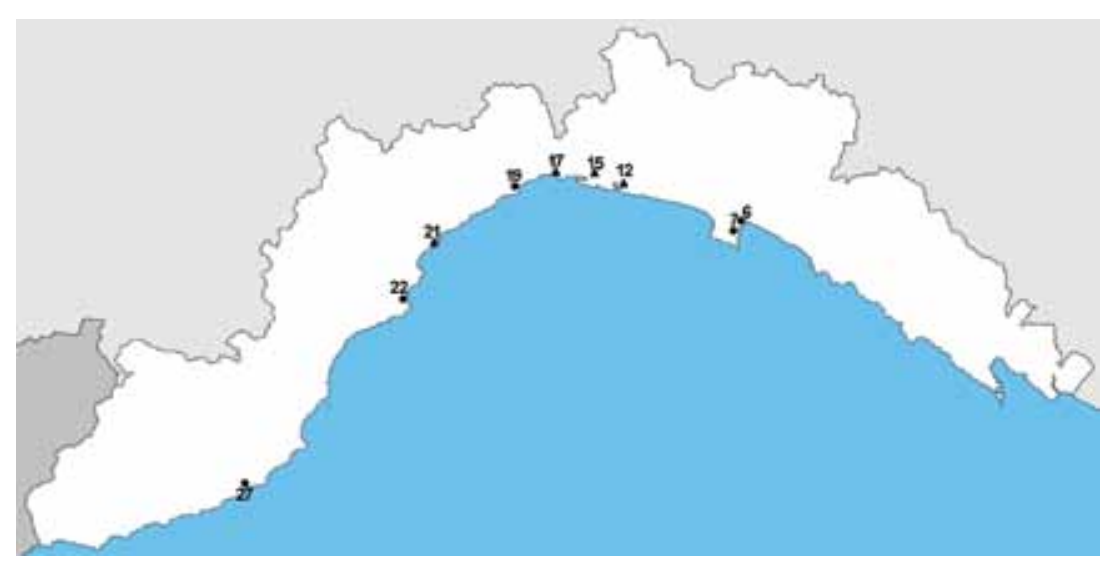

Ill. 86 - Ms. ligure: chiese d'ordine anteriori al XII secolo: 6) S. Michele di

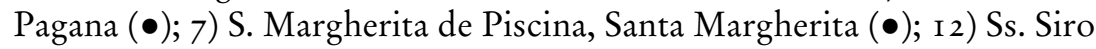

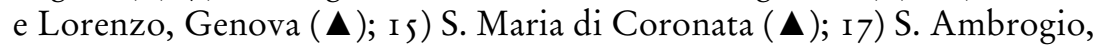

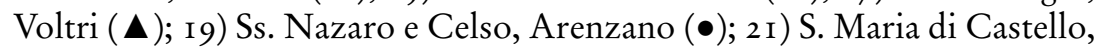
Savona $(\boldsymbol{\Lambda})$; 22) S. Paragorio, Noli $(\bullet) ; 27)$ S. Maurizio di Porto Maurizio, Imperia $(\bullet)$. 


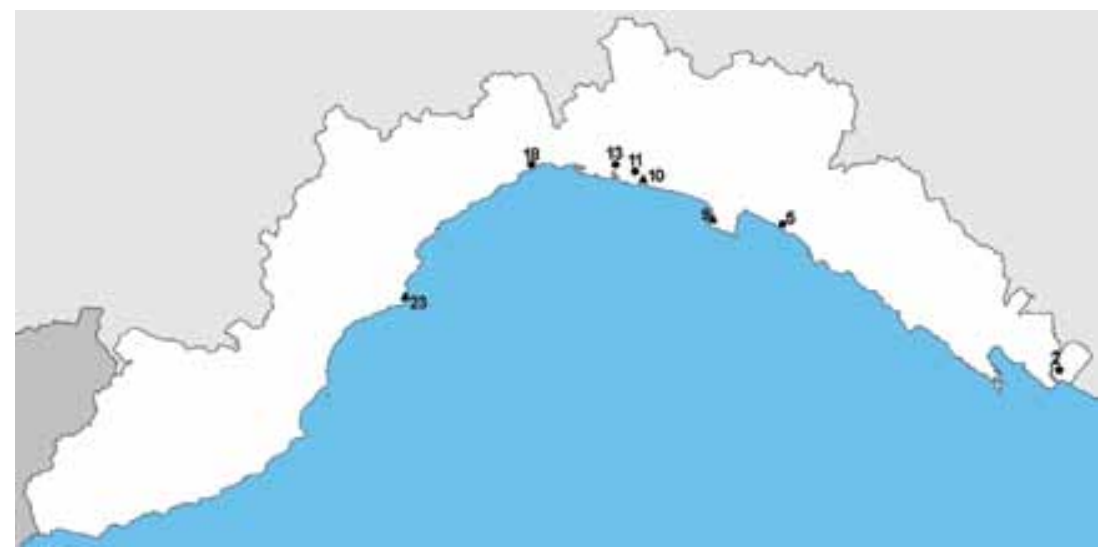

Ill. 87 -Ms. ligure: chiese fondate da Ordini basso-medievali: 2) S. Francesco

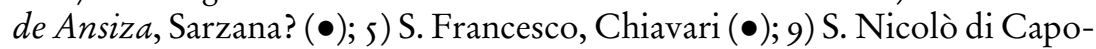

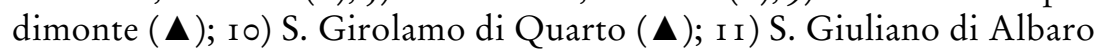

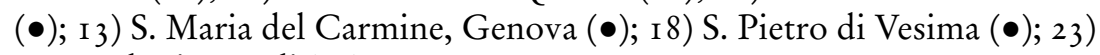
S. Margherita, Noli ( $\mathbf{\Delta})$.

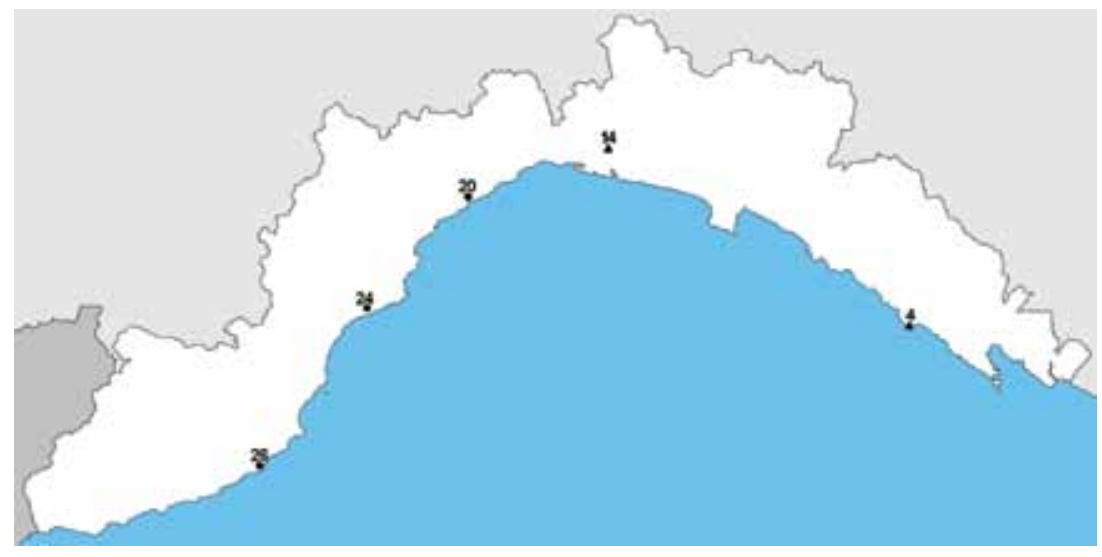

Ill. 88 - Ms. ligure: chiese modeste di fondazione basso-medievale: 4) S.

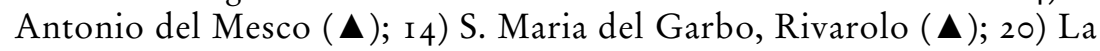

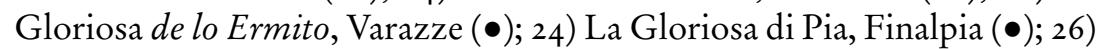
S. Erasmo, Diano $(\bullet)$. 


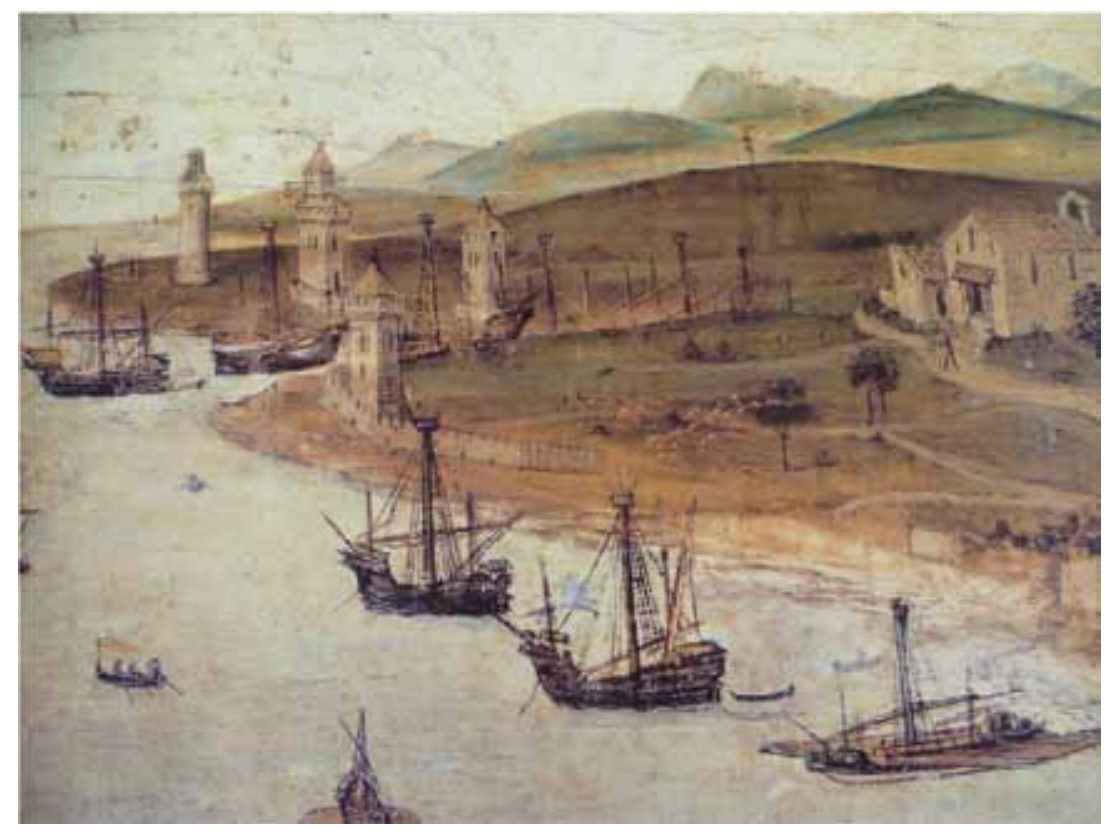

Ill. 89 - Père Nisart, Port naturel de Palma de Majorque, planche principale du retable de saint George, I 468-I 470, Palma Majorque, Societat Arqueològica Luliana. 


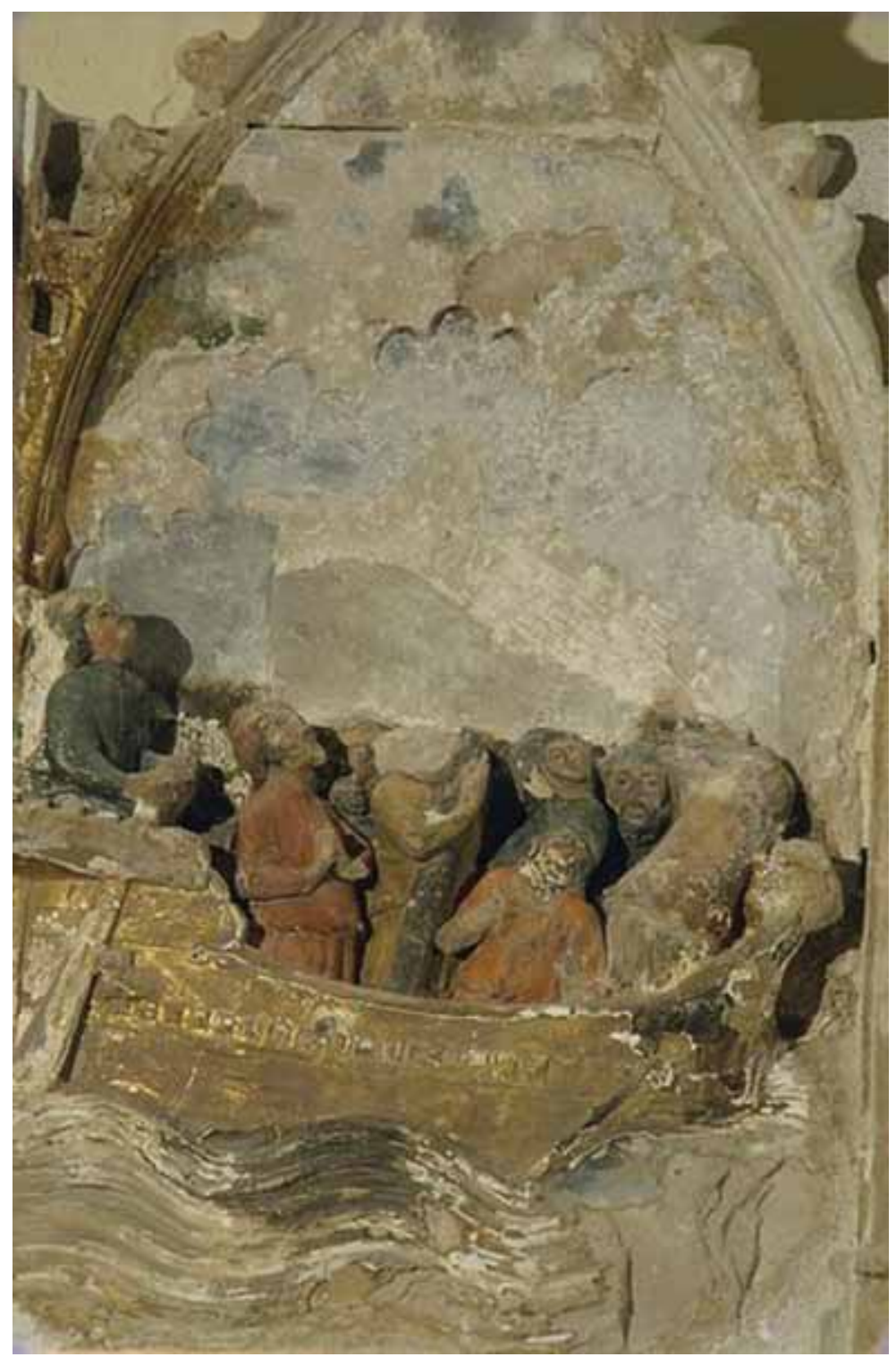

Ill. 90 - Bartomeu de Robio, retable de l'église d'Alós de Balaguer, Lérida, deuxième moitié du XIVe siècle, Saint Pierre Martyr évitant un naufrage. 


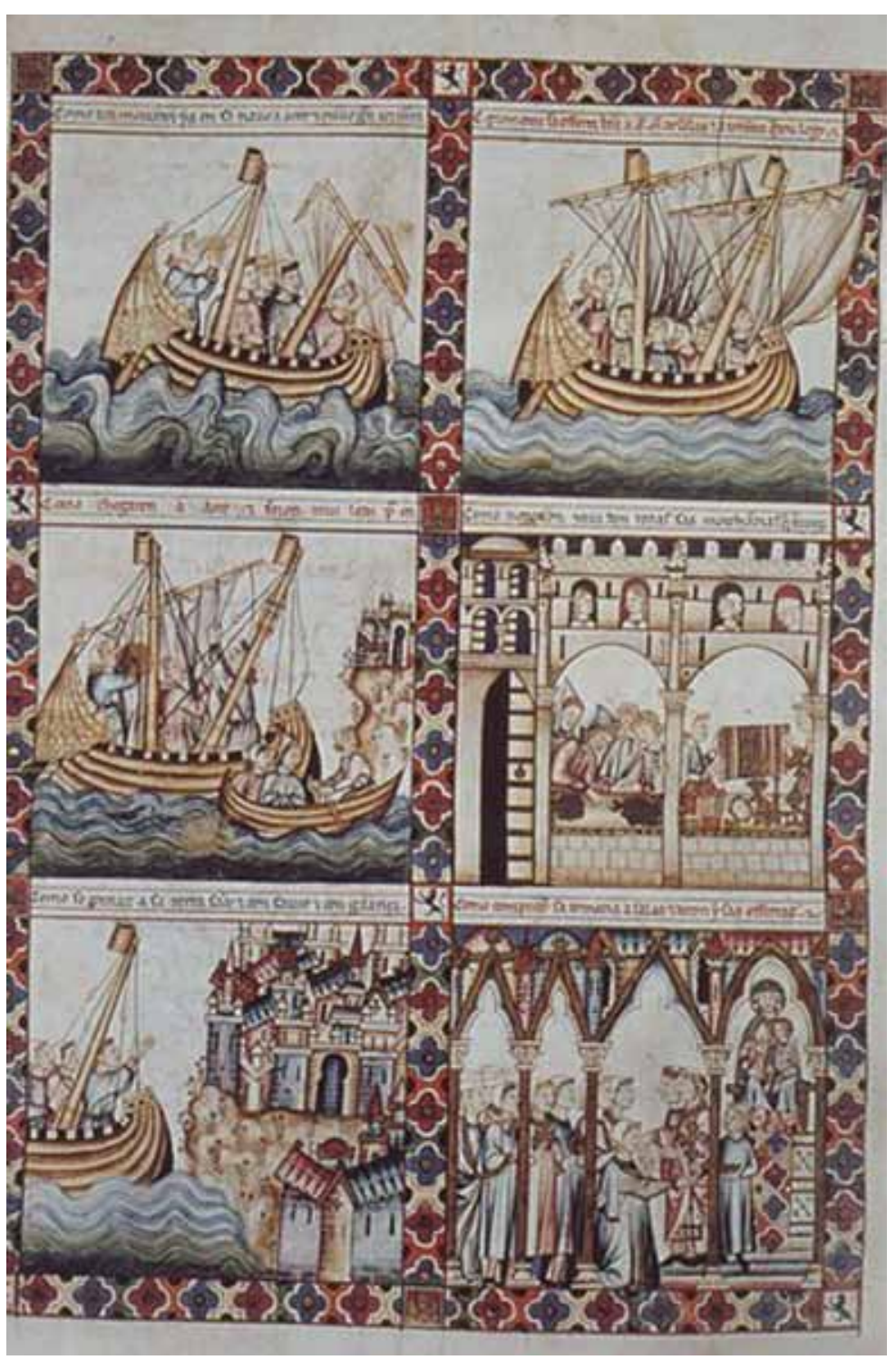

Ill. 9I - Miracle de la Vierge de Salas, Cantigas de Santa María, Cantiga I72, XIII ${ }^{\mathrm{e}}$ siècle, Bibliothèque du Monastère de San Lorenzo de El Escorial. 


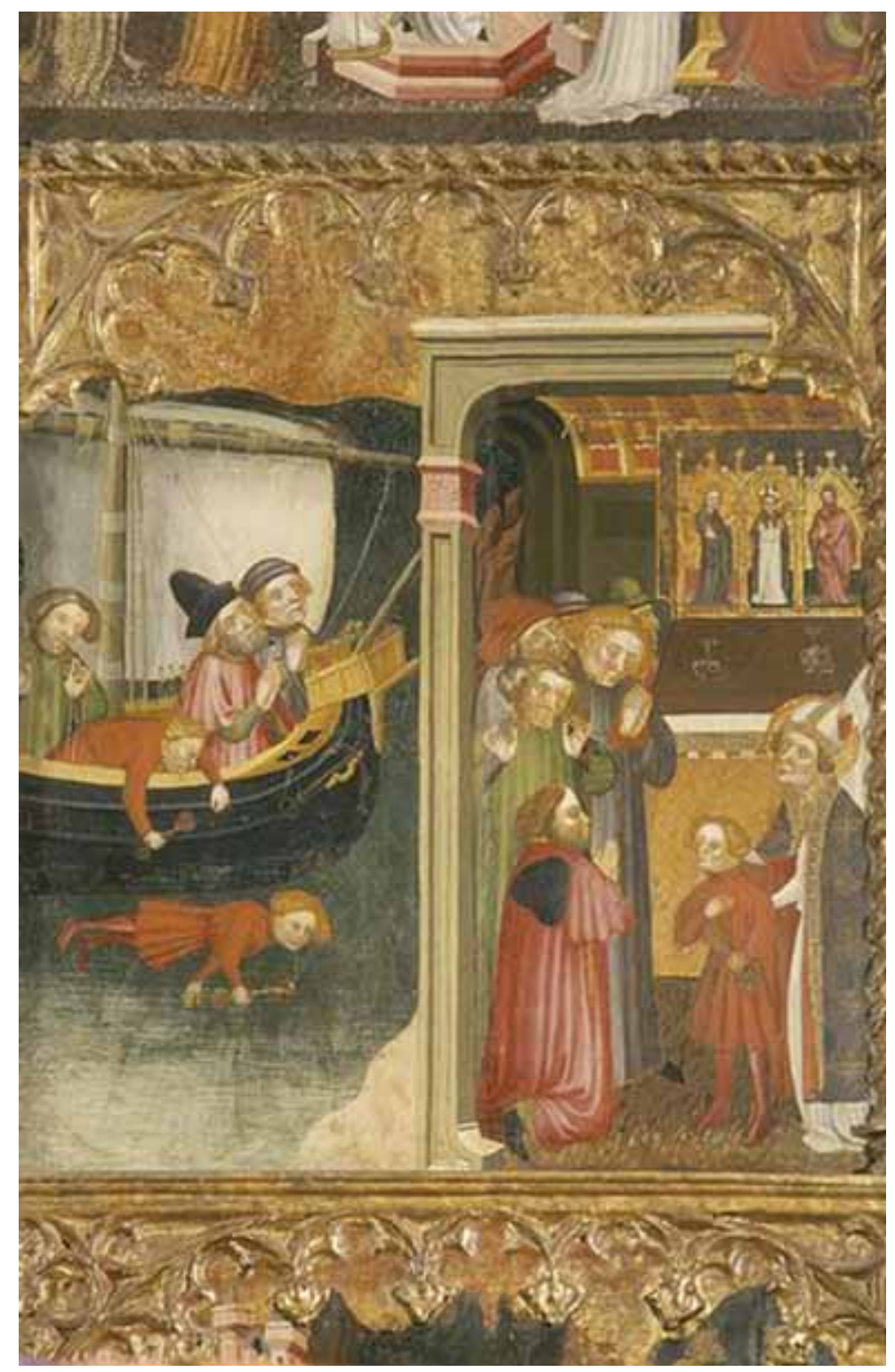

Ill. 92 - Jaume Cabrera, retable de saint Nicolás et saint Michel, ca. I405I406, Manresa, Santa María de la Aurora, Miracle maritime de saint Nicolas de Bari. 


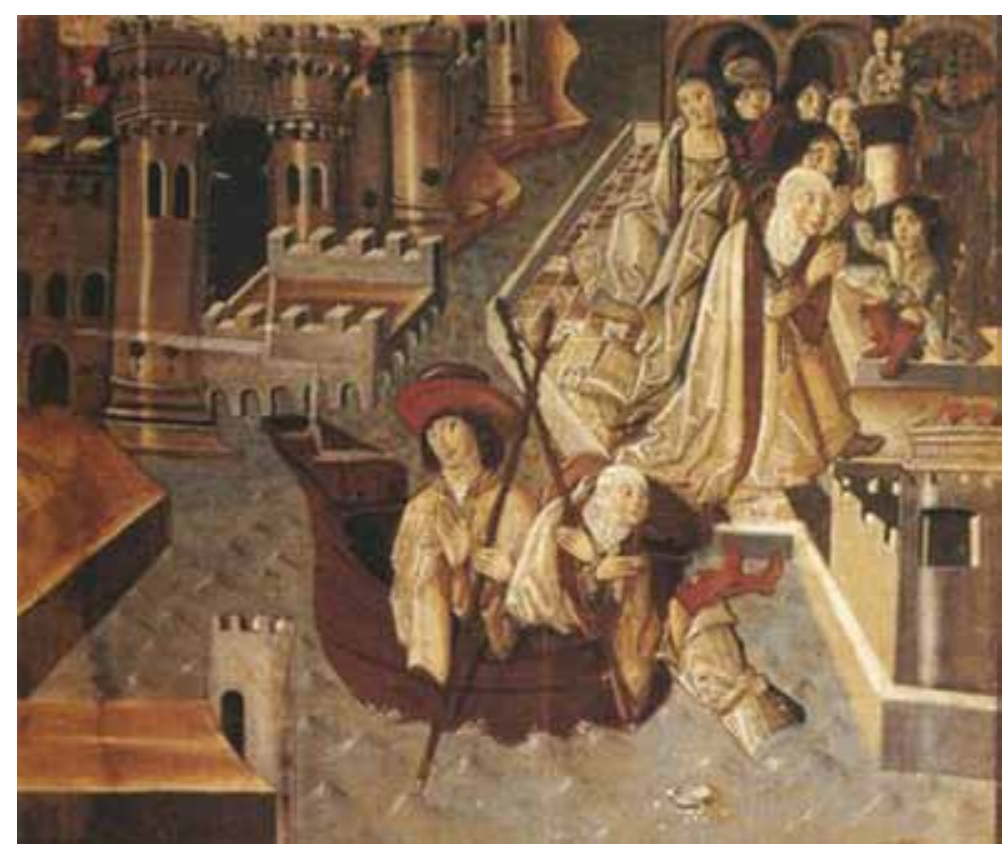

Ill. 93 - Saragosse, Cathédrale du Salvador, Peinture sur serge, ca. I490, Miracle de la Vierge del Pilar. 


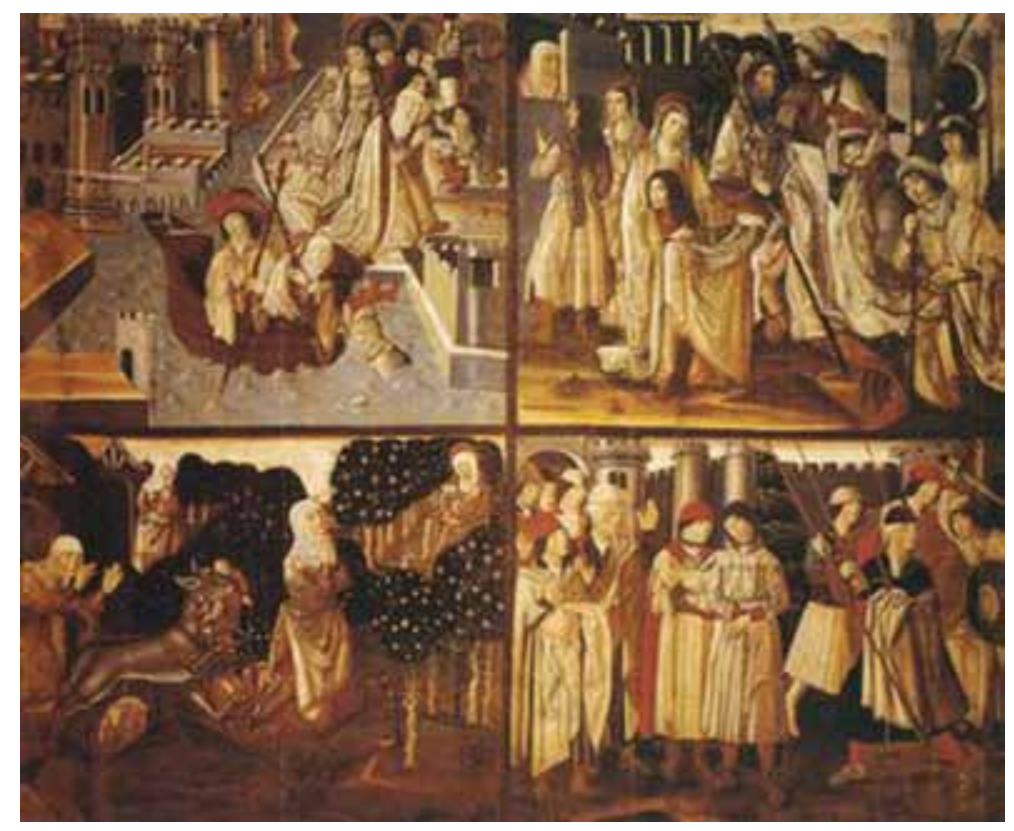

Ill. 94 - Cathédrale d'Acqui Terme, planche centrale du retable de Bartolomé Bermejo, ca. ${ }_{4} 85$, Vierge de Montserrat. 


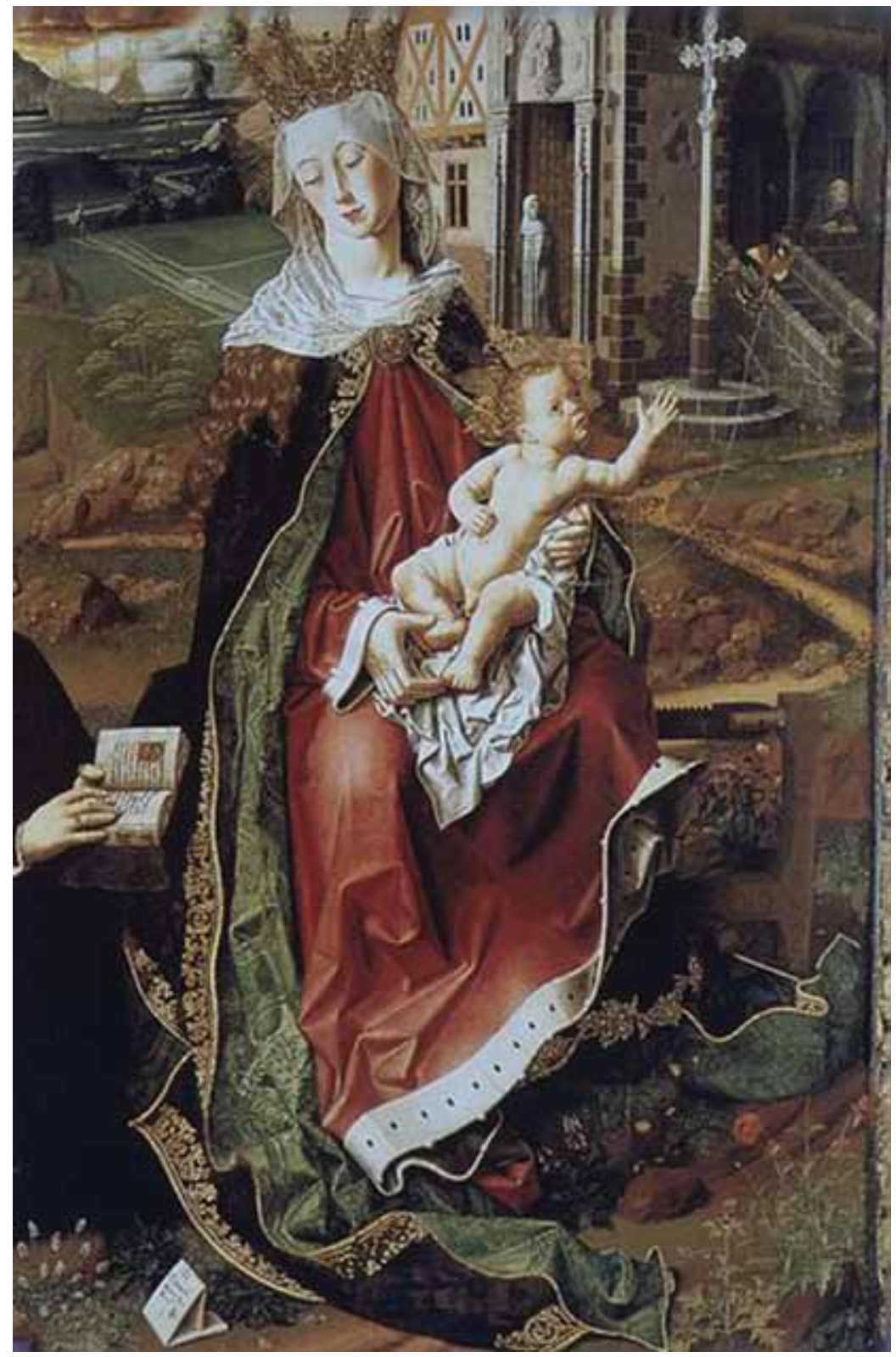

Ill. 95 - Vierge de Montserrat.,Gravure de la fin du XVe siècle. 


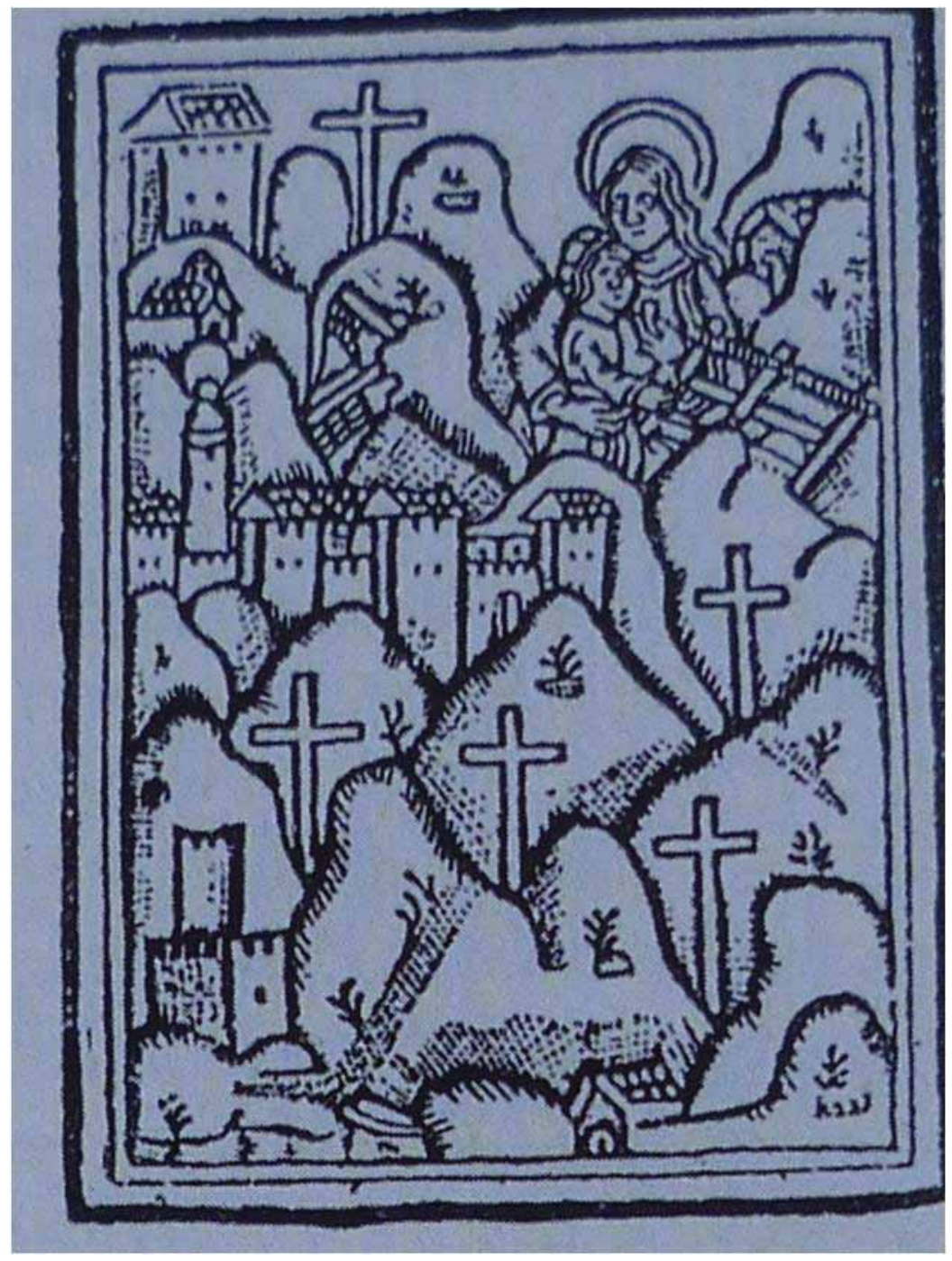

Ill. 96 - Vierge de Montserrat, Gravure de la fin du XVe siècle. 


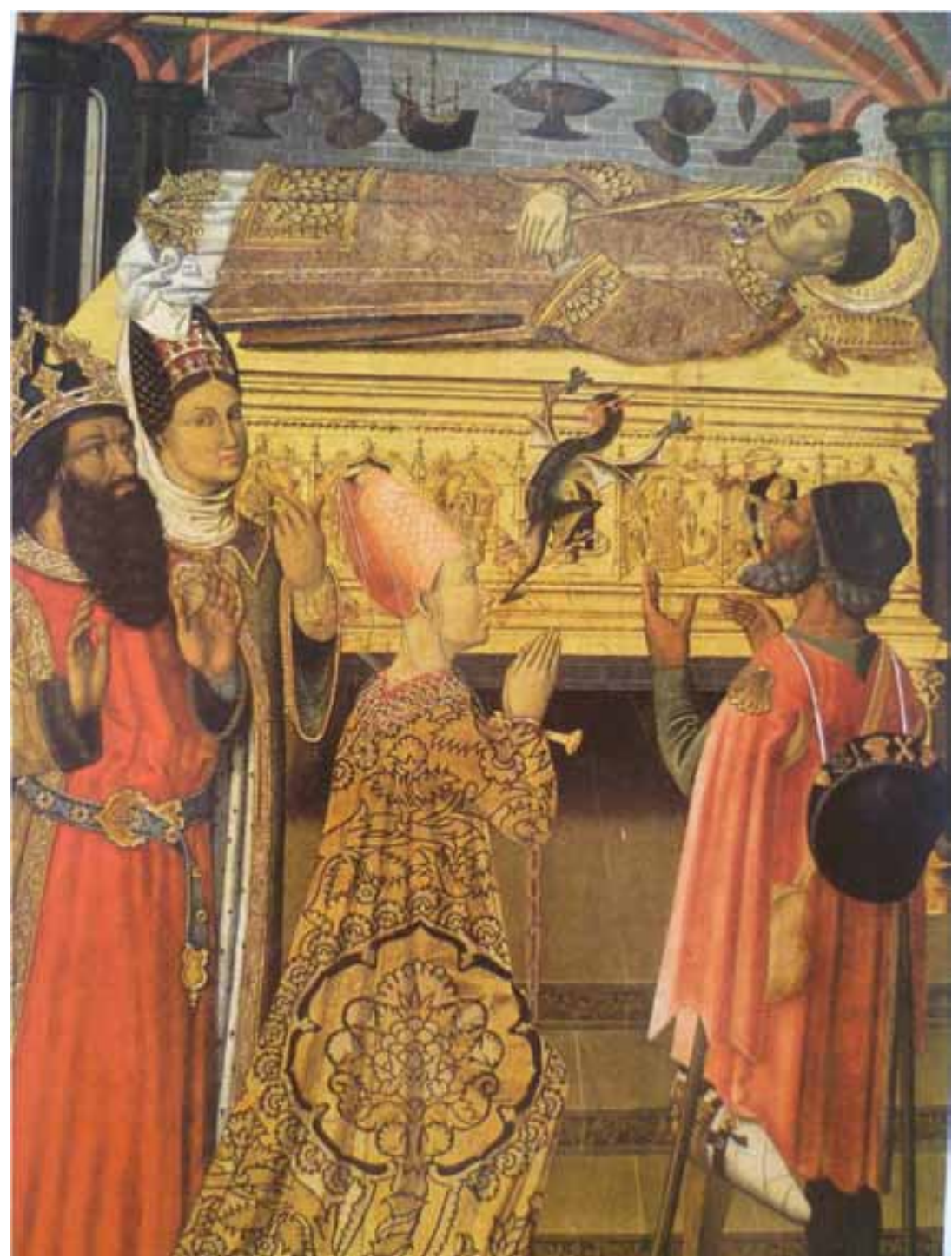

Ill. 97 - Frères Vergós, Miracle ad sepulcrum avec exposition d'ex-voto, Retable de Sant Esteve de Granollers, ca. I 500, Barcelone, Musée national d'Art de Catalogne. 


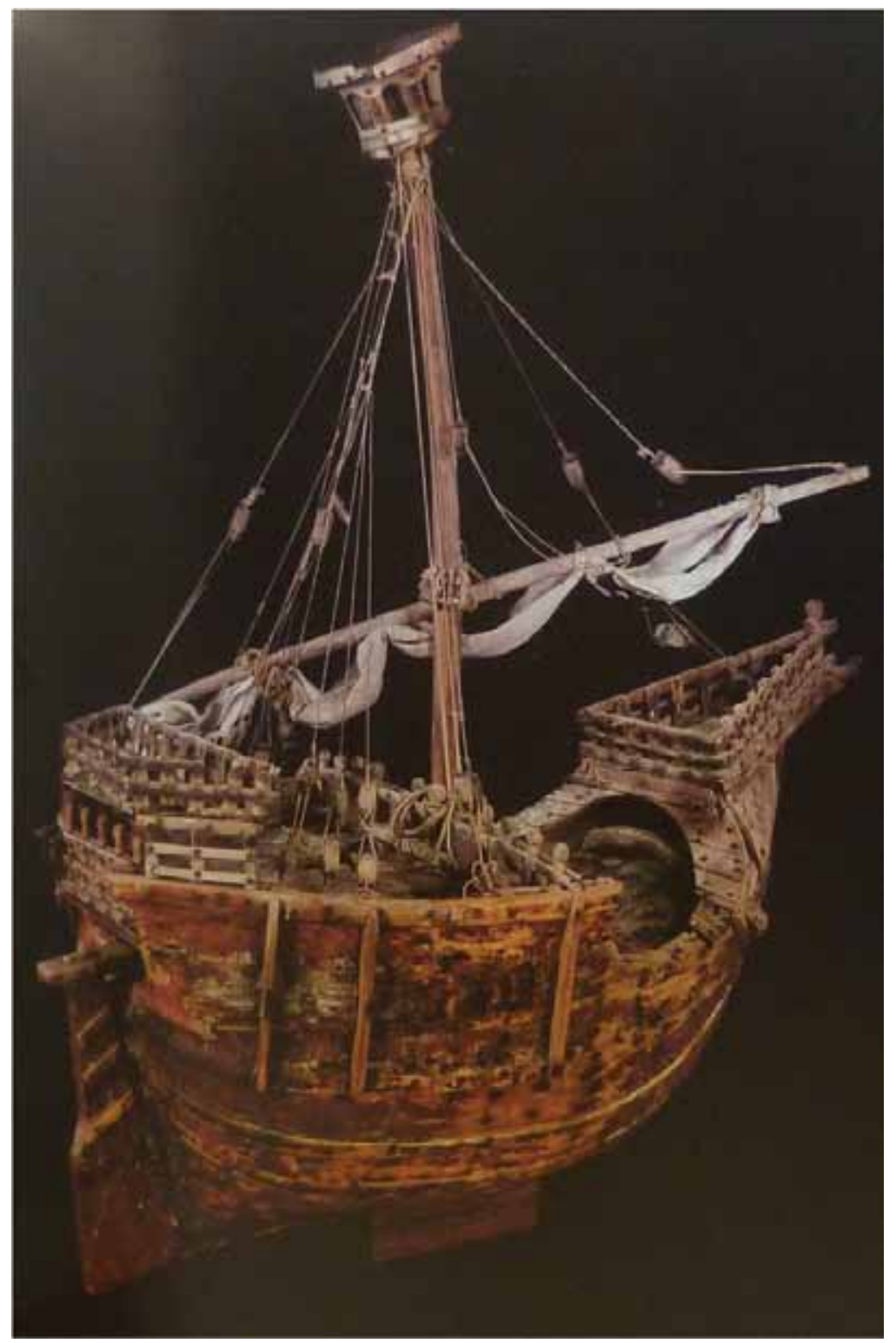

Ill. 98 - Cogue provenant de l'ermitage de Sant Simó de Mataró, au nord de Barcelone, XVe siècle, Rotterdam, Musée maritime. 


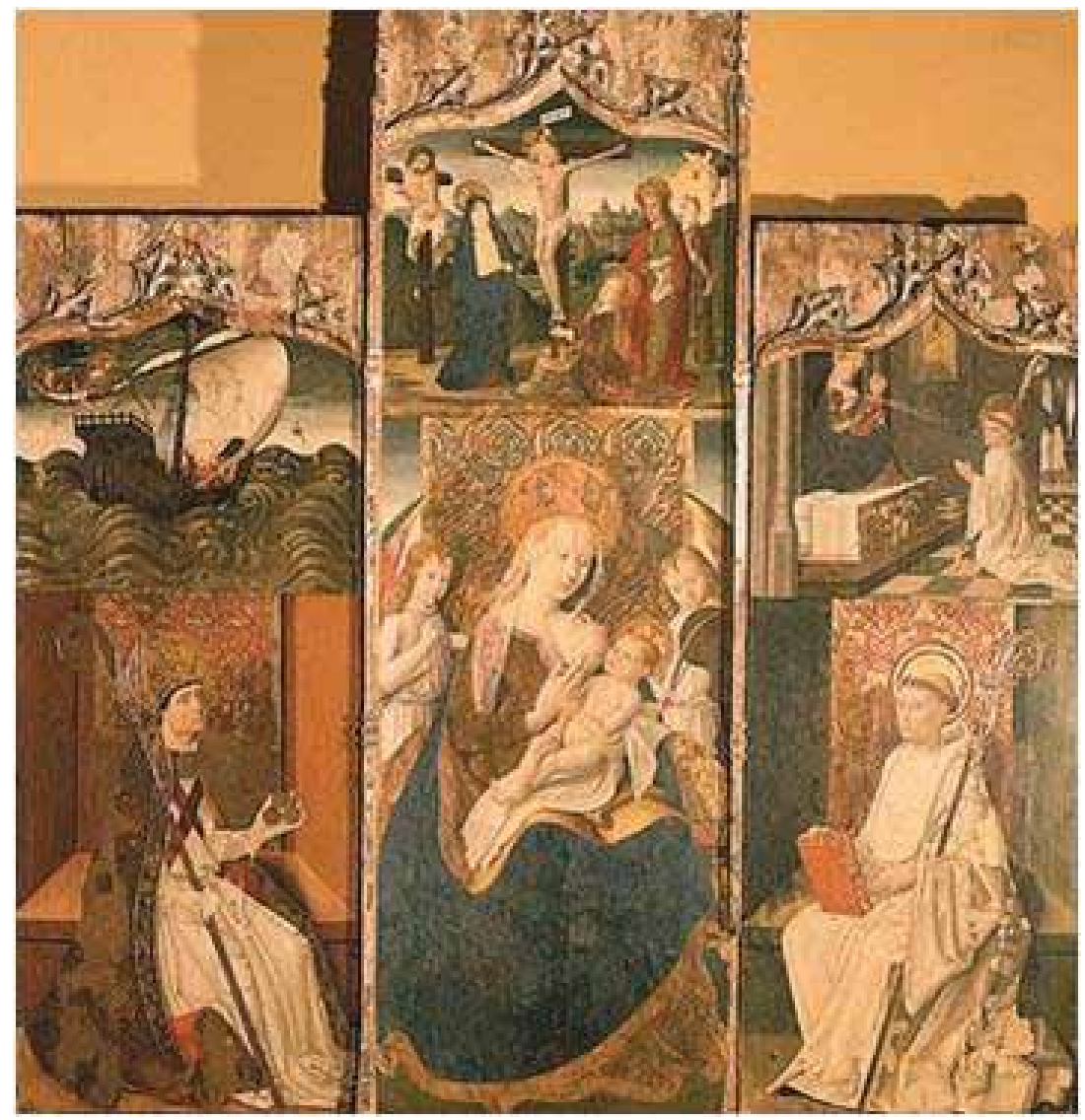

Ill. 99 - Miracle maritime, Retable de Canapost, ca. I 500, Gérone, Musée d'Art. 


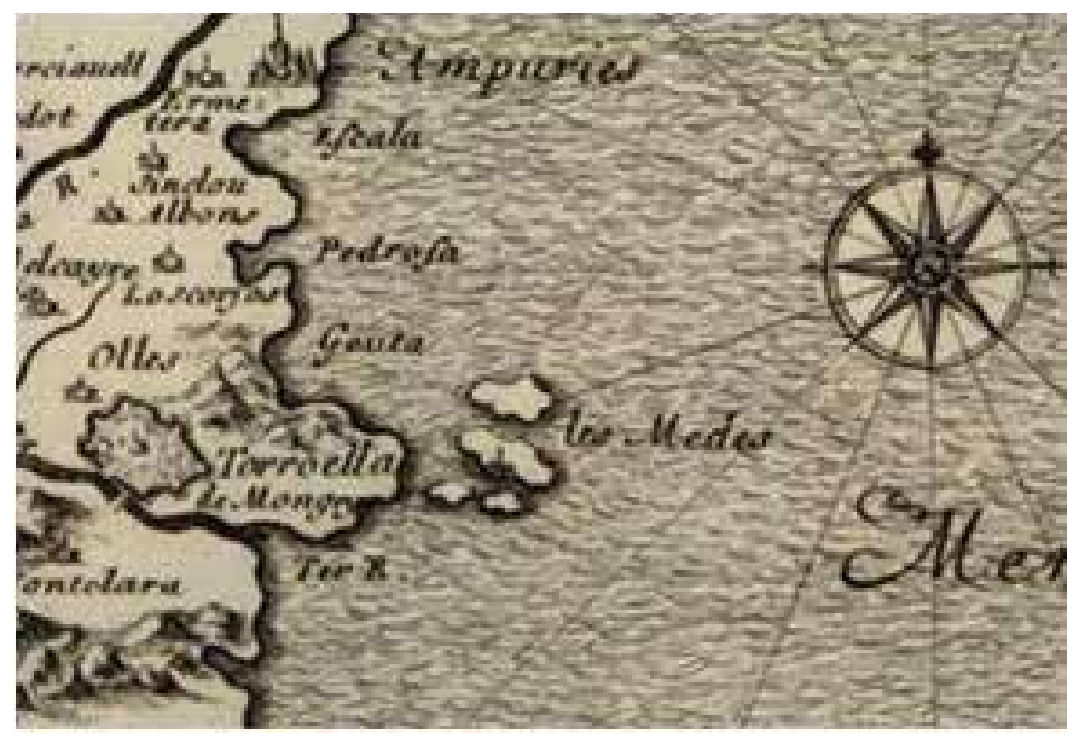

Ill. 100 - Îles Medes sur la côte de Gérone, où se trouve depuis le haut Moyen Âge un sanctuaire dédié à saint Michel. 


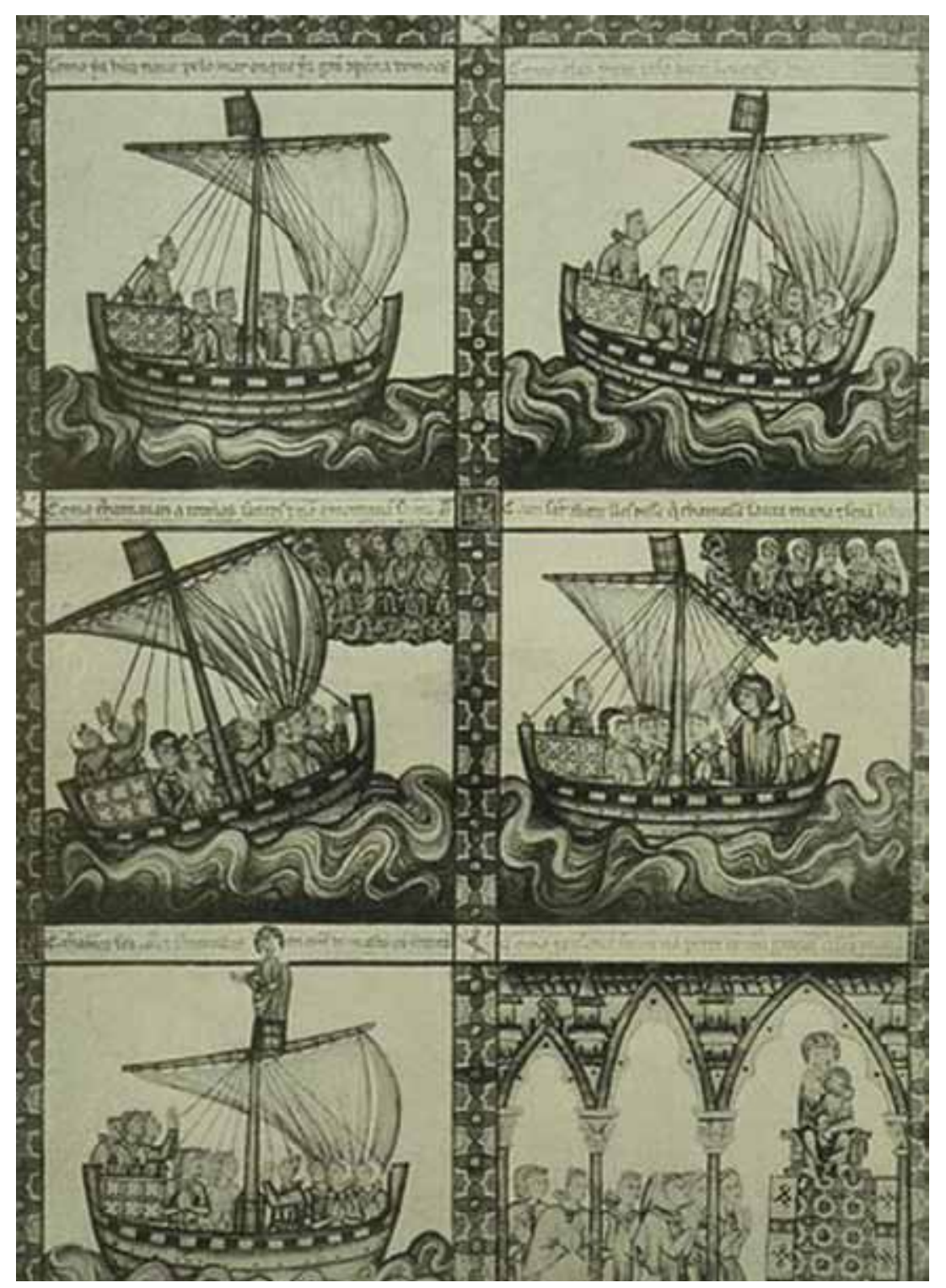

Ill. ıo I - Miracle maritime, Cantigas de Santa María, Cantiga 36, XIII siècle, Bibliothèque du Monastère de San Lorenzo de El Escorial. 


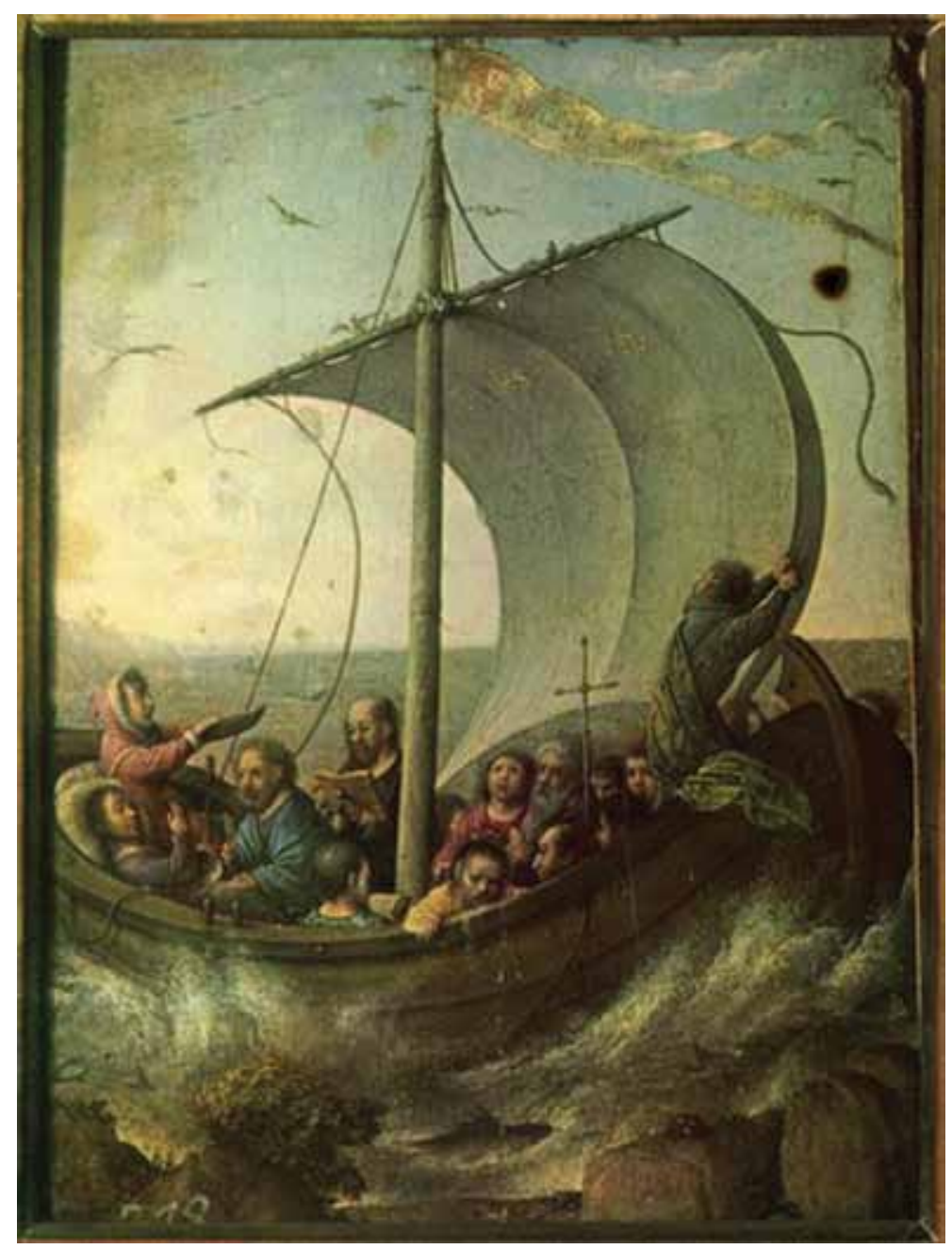

Ill. I02 - Juan de Flandes, miracle maritime, retable d'Isabelle de Castille, dite la Católique, ca. I 500, Grenade, Chapelle royale. 


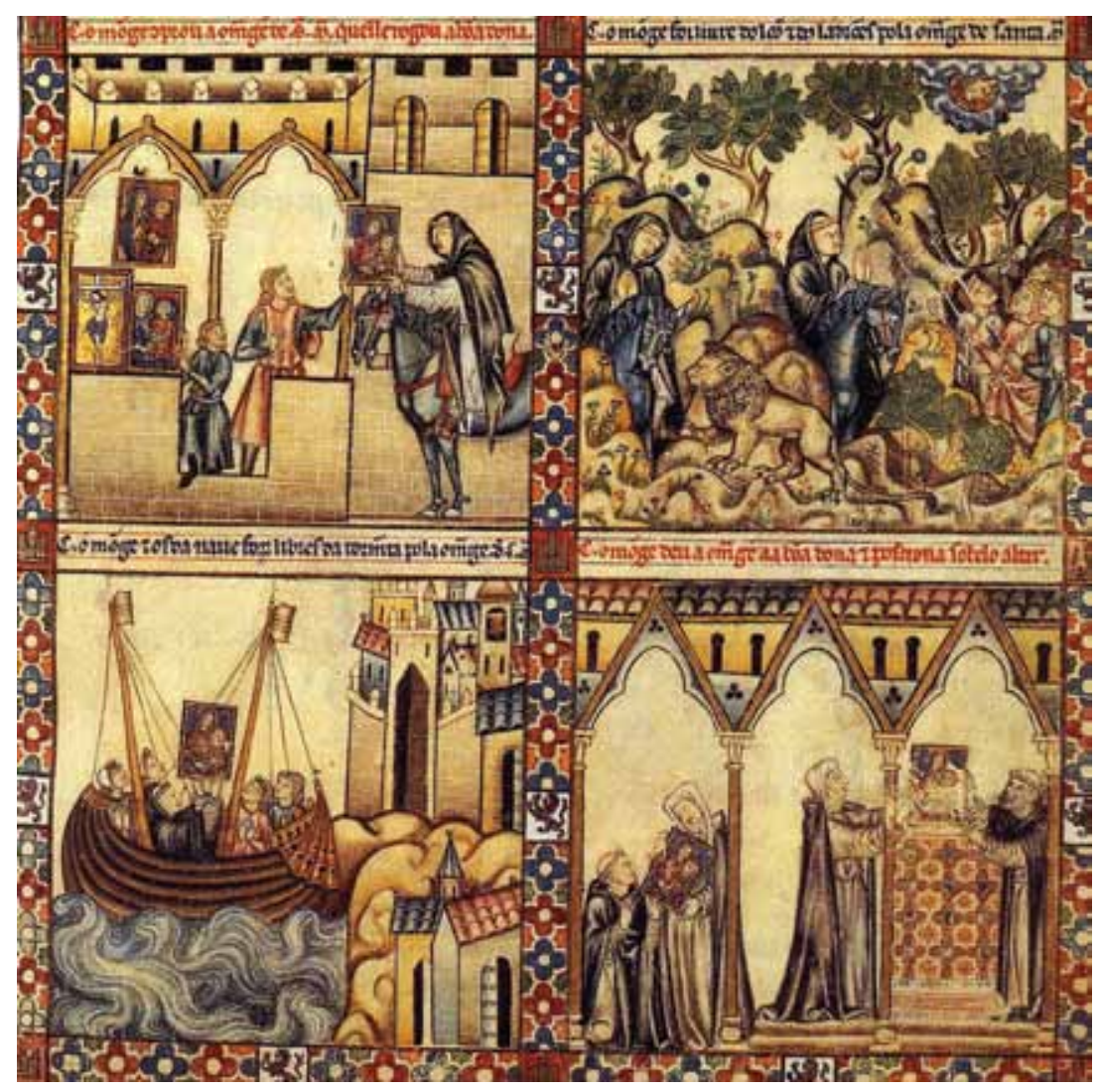

Ill. I03 - Illuminator of Alfonso's X workshop, Miniature of Cantigas de Santa María, Rich Codex, ca. I 272-I 284, San Lorenzo de El Escorial, Biblioteca del Real Monasterio, T-I-I, cantiga 9, f. I7r (Patrimonio Nacional). 


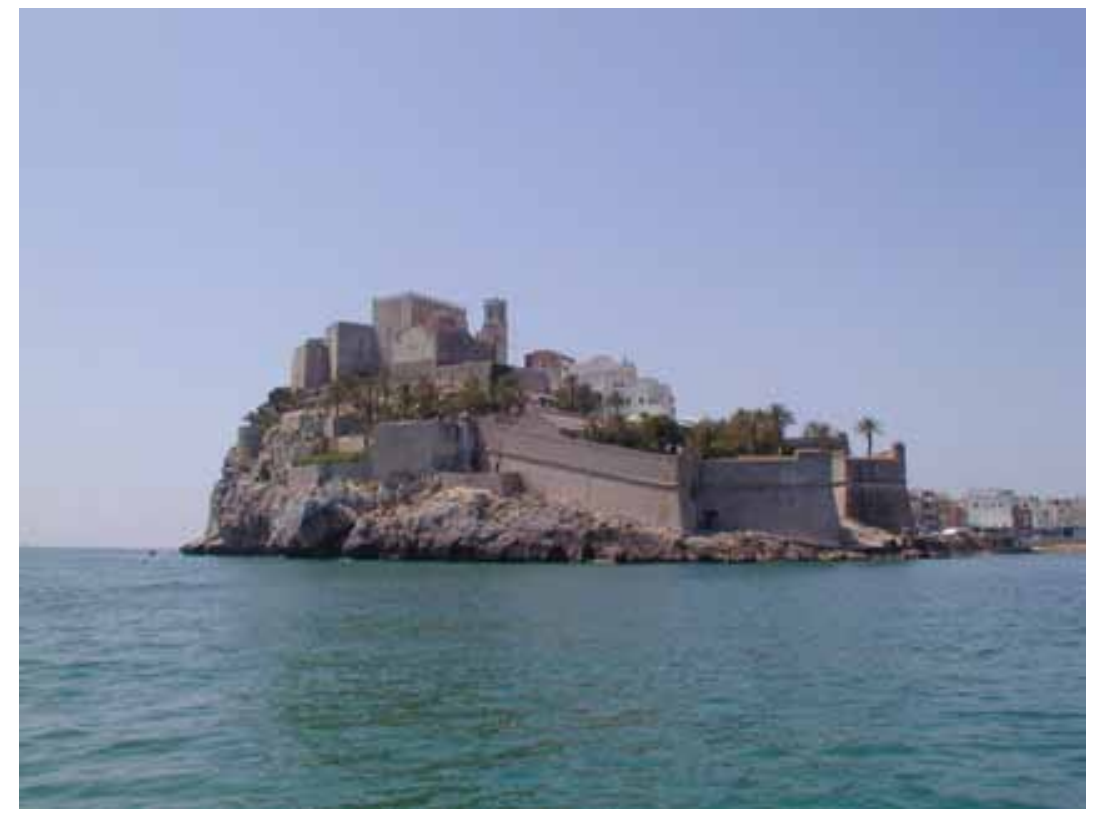

Ill. ro4 - Peñiscola (Castellón), the castle and the medieval city. 


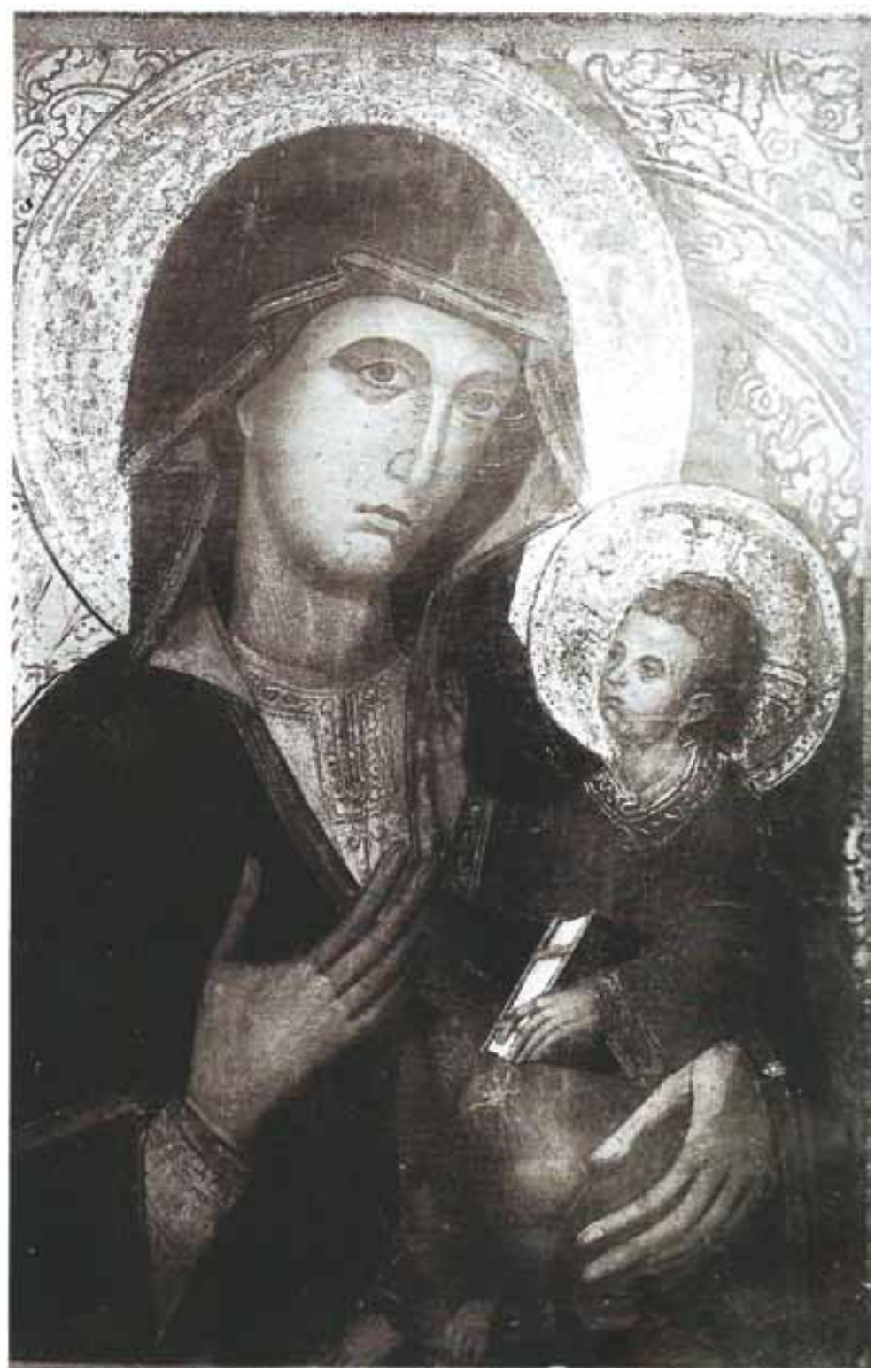

Ill. Ios - Mediterranean painter, Our Lady of the See (Nuestra Señora de la Seo), Icon, $3^{\text {th }}$ century, Valencia, Cathedral (before I936). 


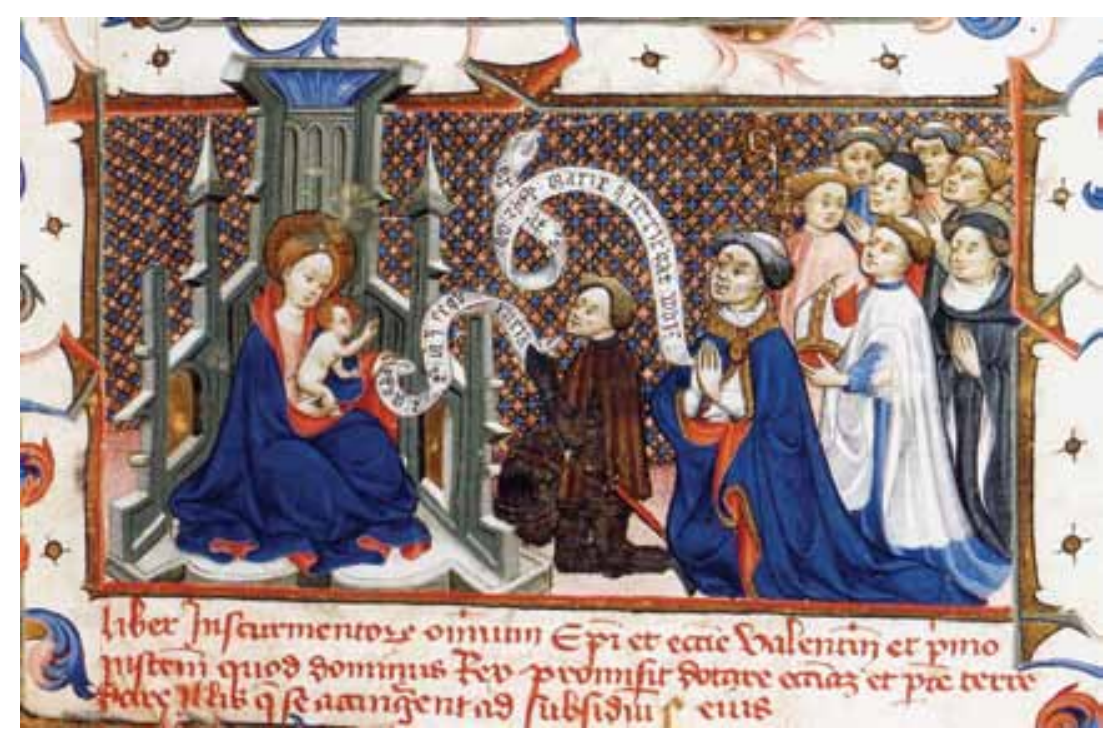

Ill. 106 - Liber Instrumentorum Master (Domingo Adzuara?), Miniature of King James I and the Bishop of Valencia offering the foundation of the new Cathedral to Saint Mary, Valencia, Cathedral, Biblioteca Capitular, ms. I62, f. 6 r. 


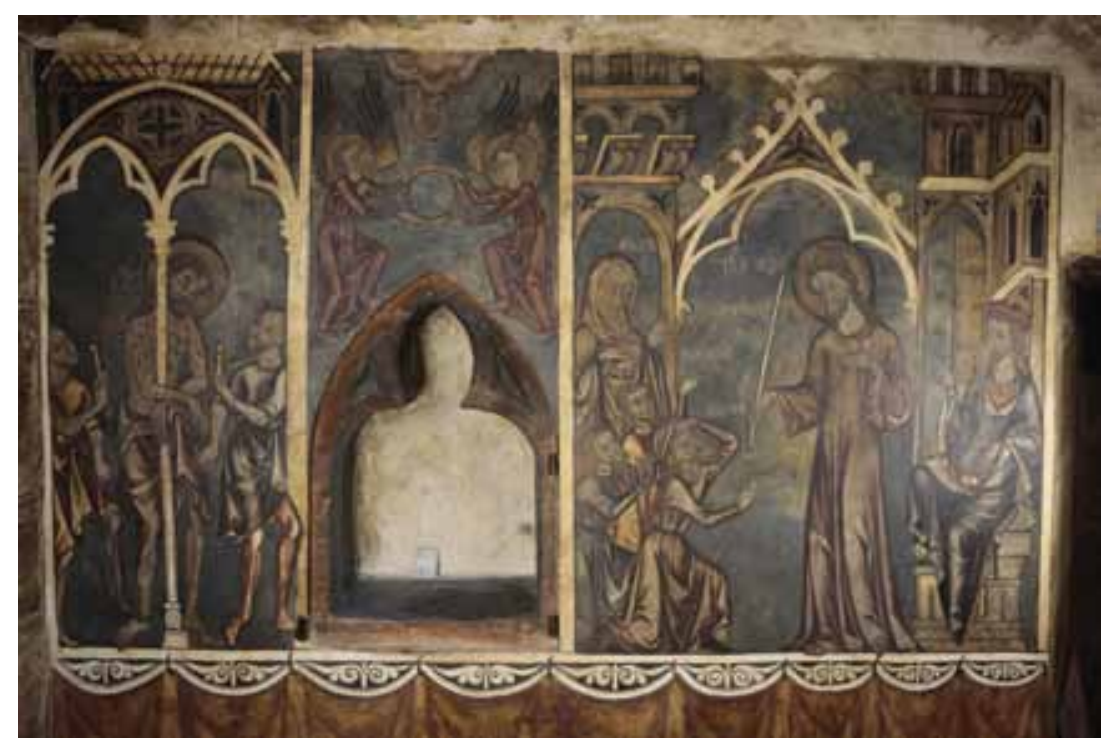

Ill. 107 - Painter from the Crown of Aragon, Wall paintings with scenes of Christ's Passion, ca. I 256-I 280, Cathedral, secret chamber (reconditorio), (Image courtesy of Subdirección de Conservación, Restauración e Investigación IVC+R [Culturarts], Generalitat Valenciana. 


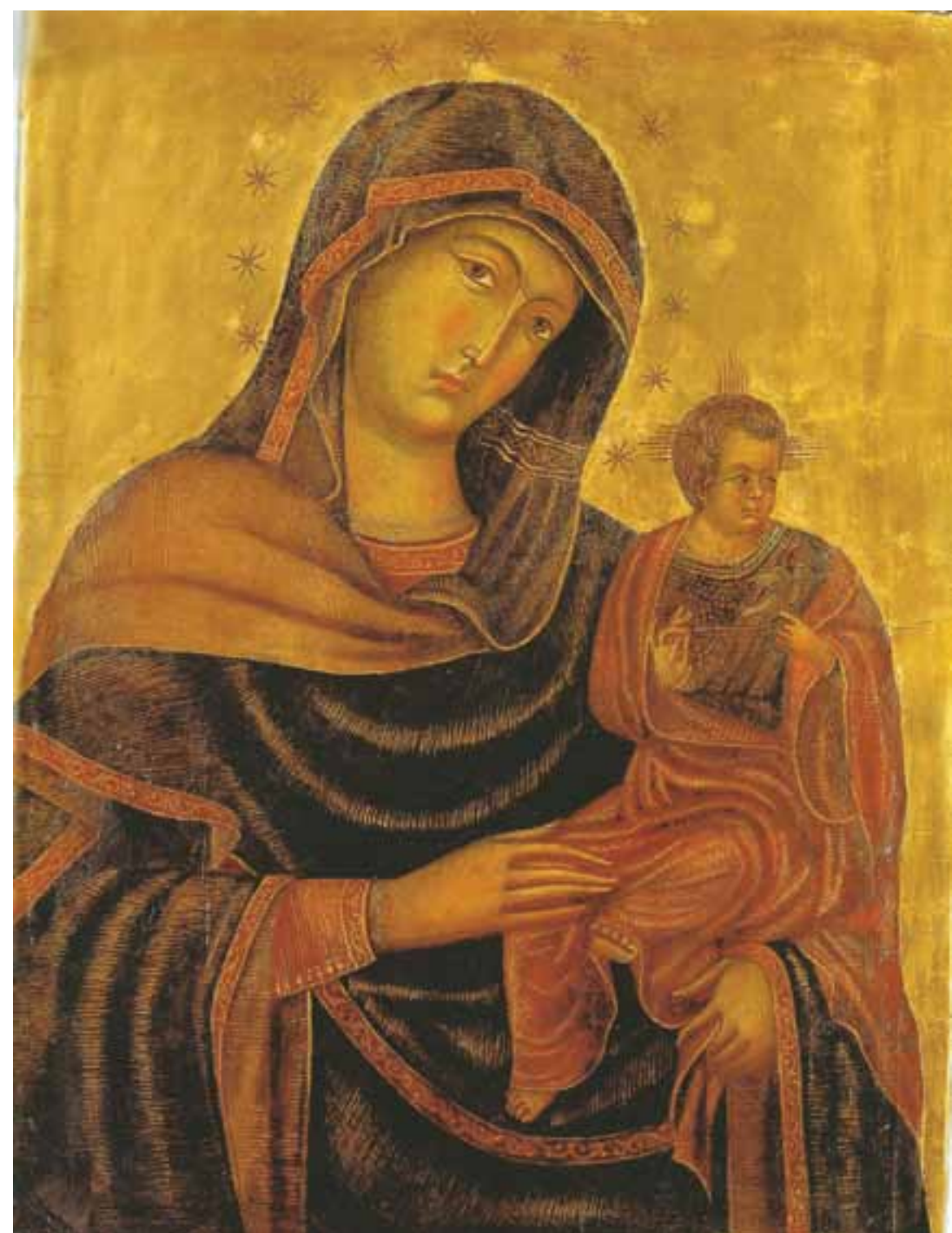

Ill. I08 - Italian painter, Our Lady of Grace (Nuestra Señora de Gracia), ca. I 270-I 300, Valencia, Saint Augustine’s parish church. 


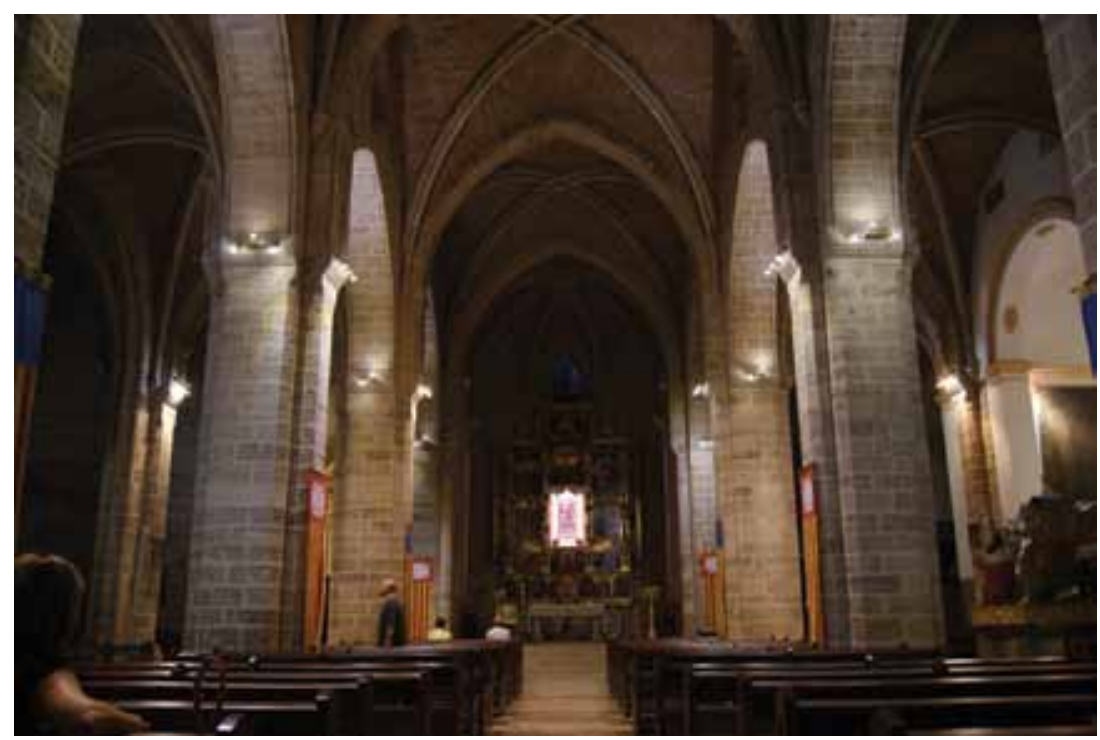

Ill. I09 - Valencia, El Puig de Santa María, Monastery of Santa María del Puig, I 3 th-I 8 th centuries. 


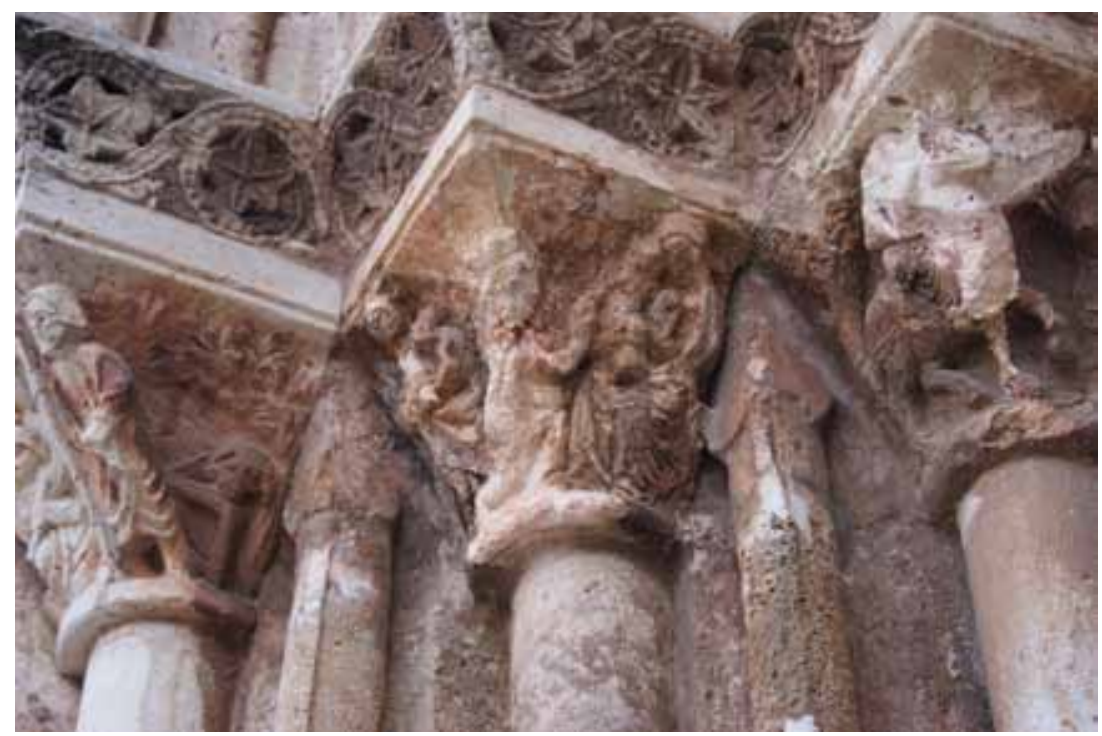

Ill. I Io - Valencia, El Puig de Santa María, Capital on the portal of the church of Saint Mary, I 3 th century, Sculpture workshop from the Crown of Aragon. 


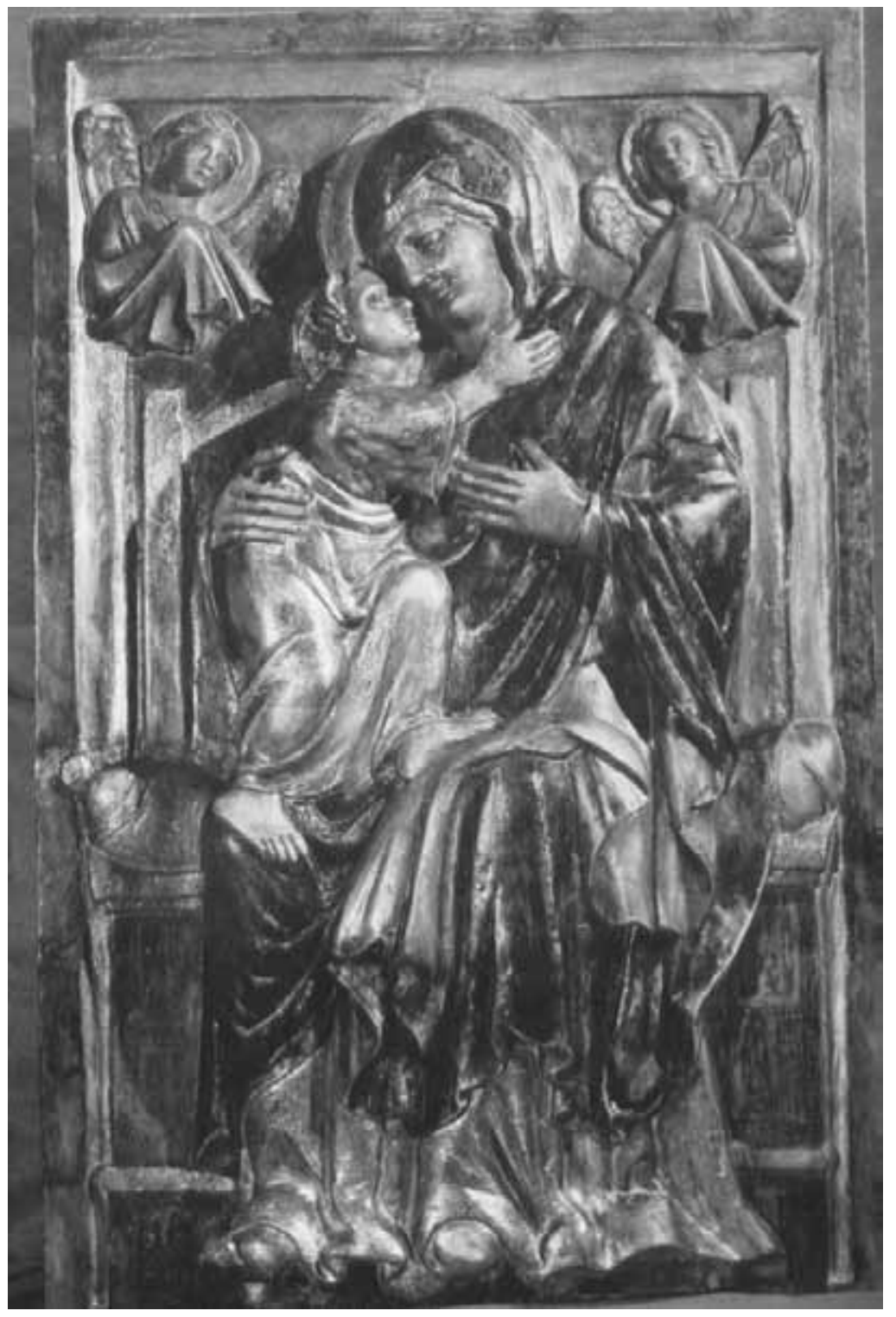

Ill. I I - Valencia, El Puig de Santa María, Monastery of Santa María del Puig, Madonna with Child, Relief Icon, second half of the I 3 th century Italian sculptor. 


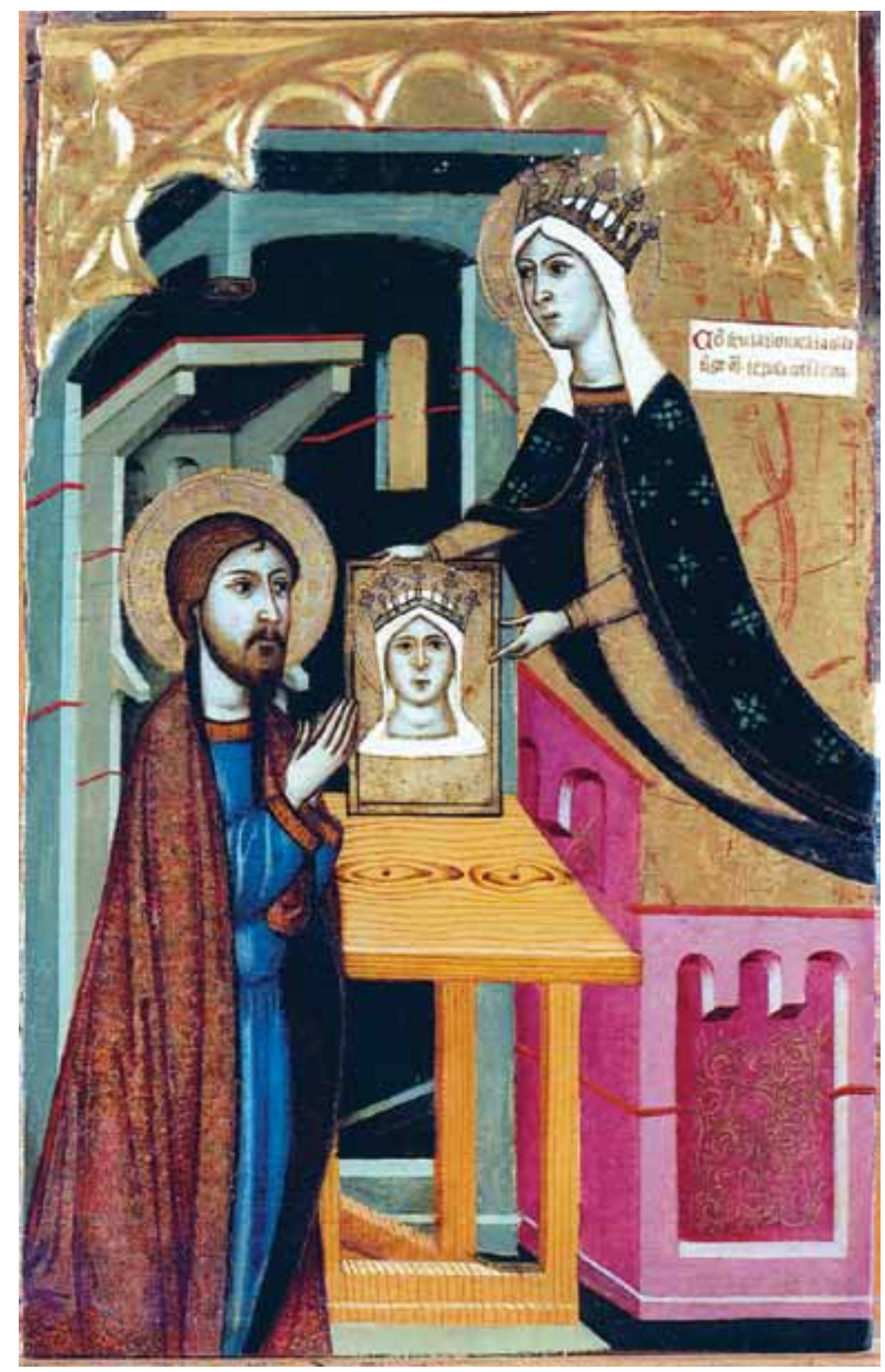

Ill. I I 2 - Llorenç Saragossà (attributed to), Saint Luke receives an icon with the portrait of Saint Mary, ca. I 370-1380, Valencia, Museo de Bellas Artes. 


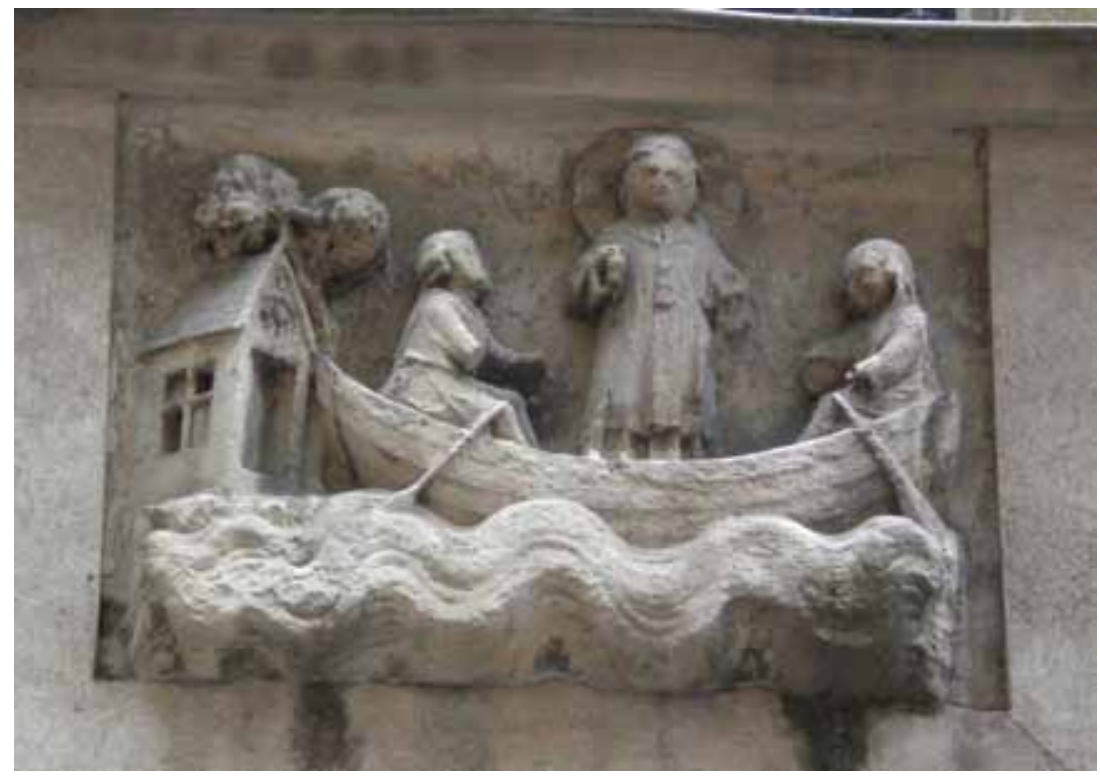

Ill. I 3 - Paris, enseigne sculptée dans la rue Garlande, la translation de Saint Jacques. 


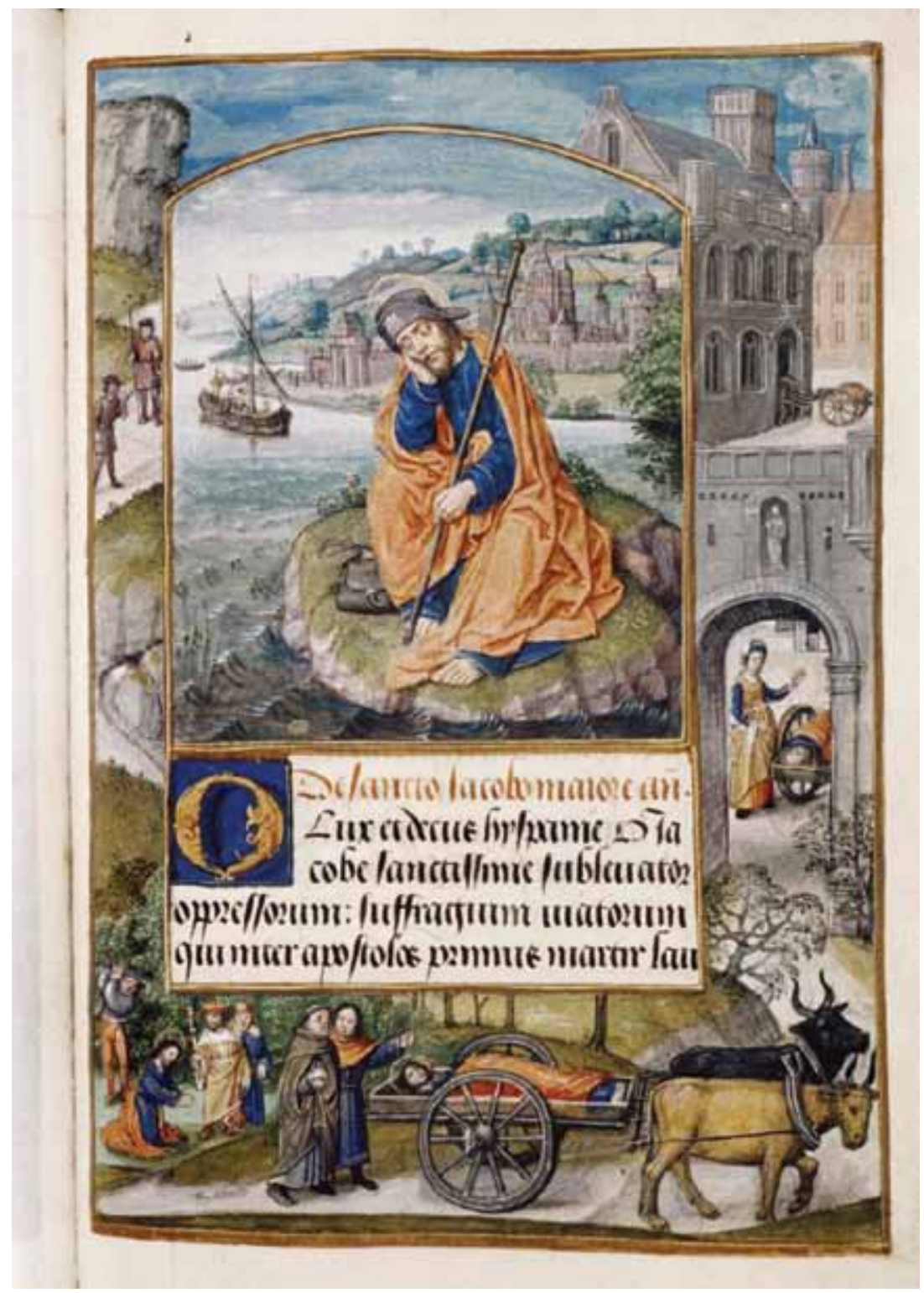

Ill. I I 4 - Saint Jacques part évangéliser l'Espagne (Oxford, Bodleian, Ms. Douce I I 2, fo I 5 Ir, Book of Hours, Use of Rome, Flemish, Early i6th century). 


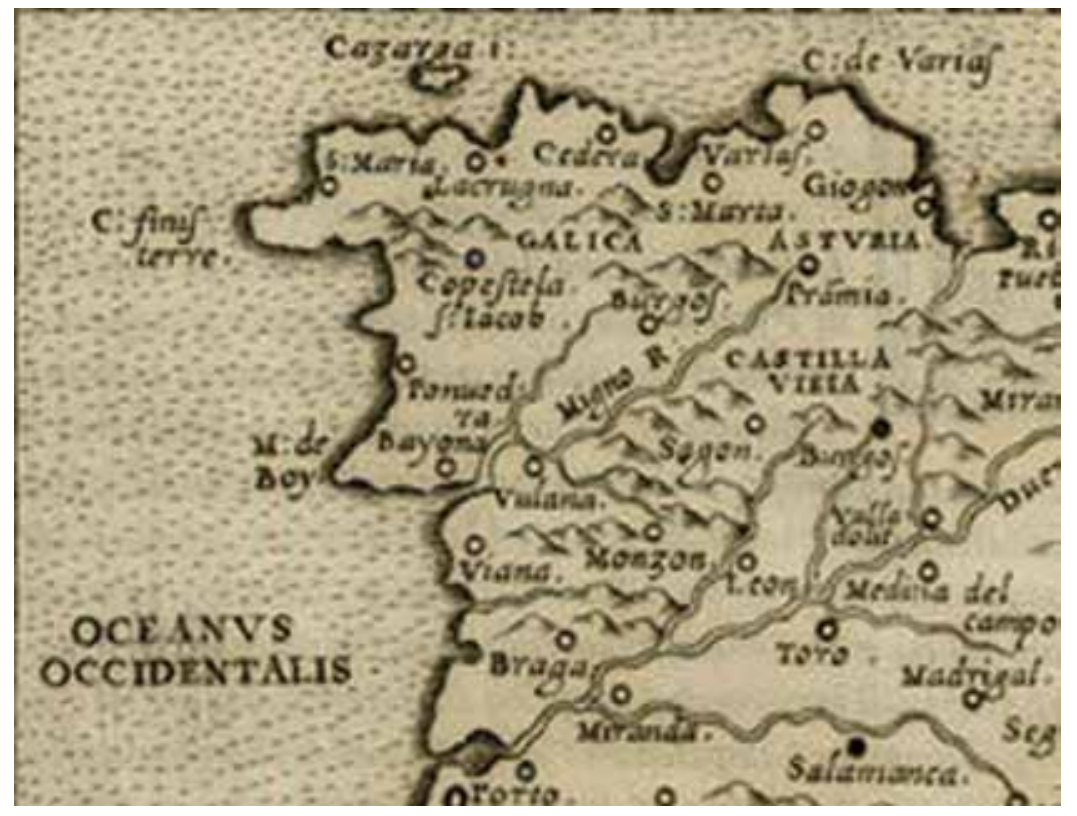

Ill. i I - La Galice (Hispania Nova Tabula, I 56 I, détail). 


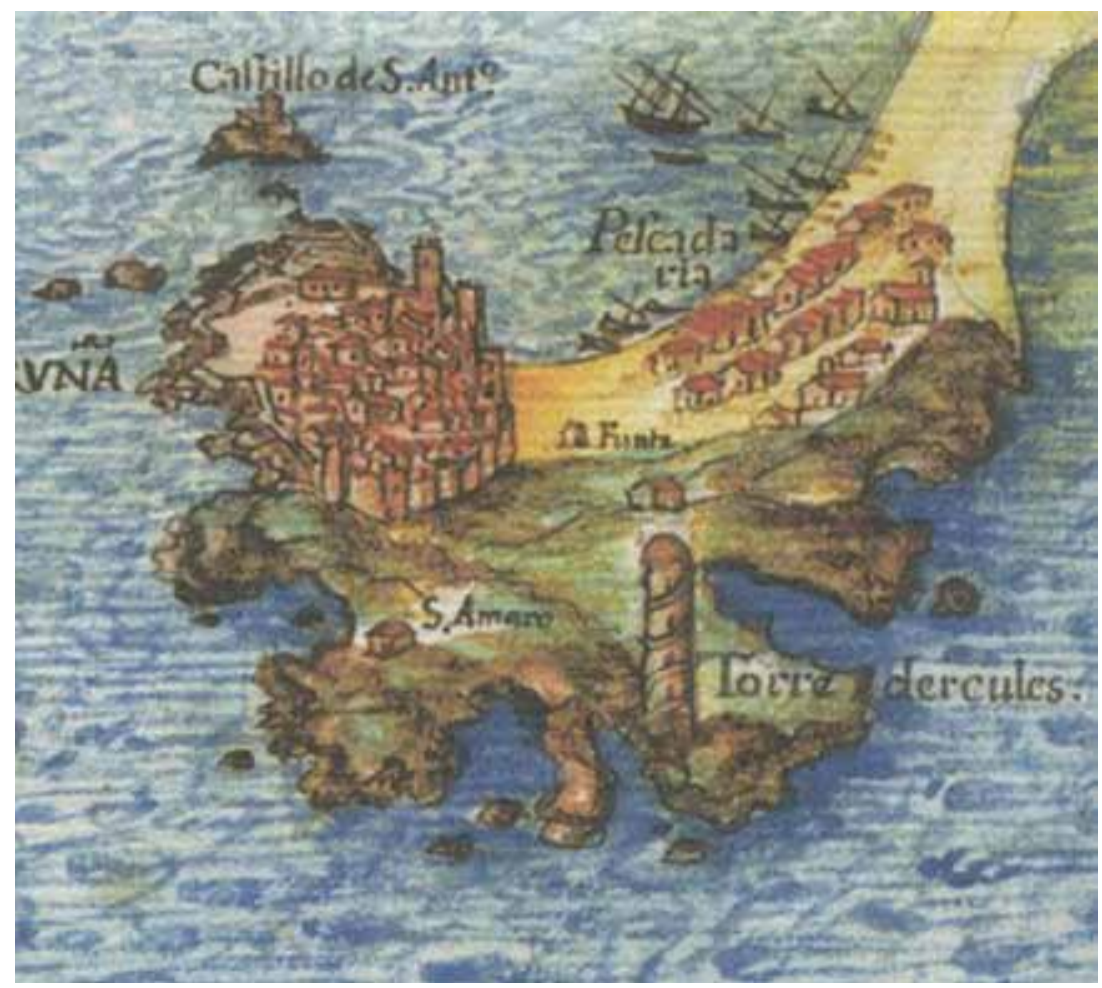

Ill. i 6 - Le port de La Corogne avec la Tour d'Hercule (Atlas de Pedro Texeira, 1634). 


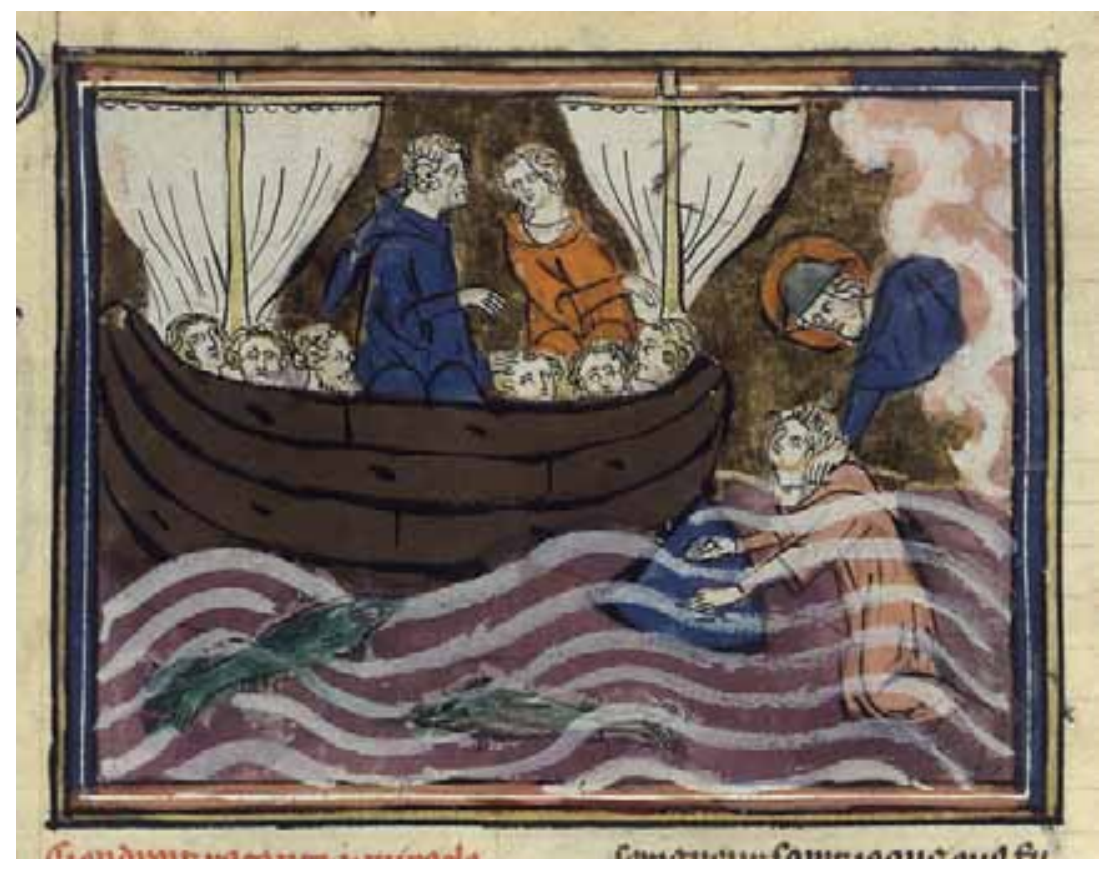

Ill. I 17 - Saint Jacques sauve un pèlerin tombé à la mer (Paris, BN, ms. français I 83 , fo 4 IV, XIVe $s$.). 


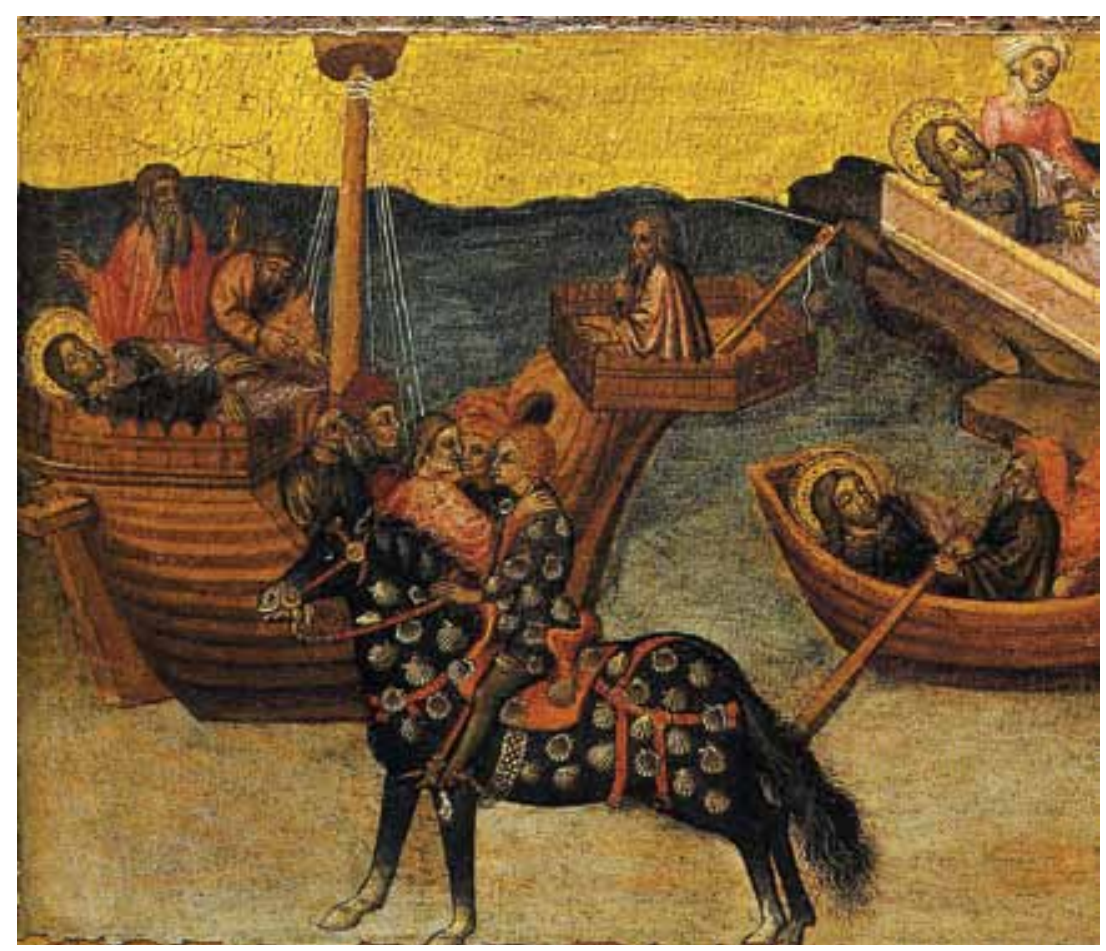

Ill. I I 8 - Le miracle des coquilles (Translation de saint Jacques, détail du retable de Camerino, Italie, Musée diocesain). 


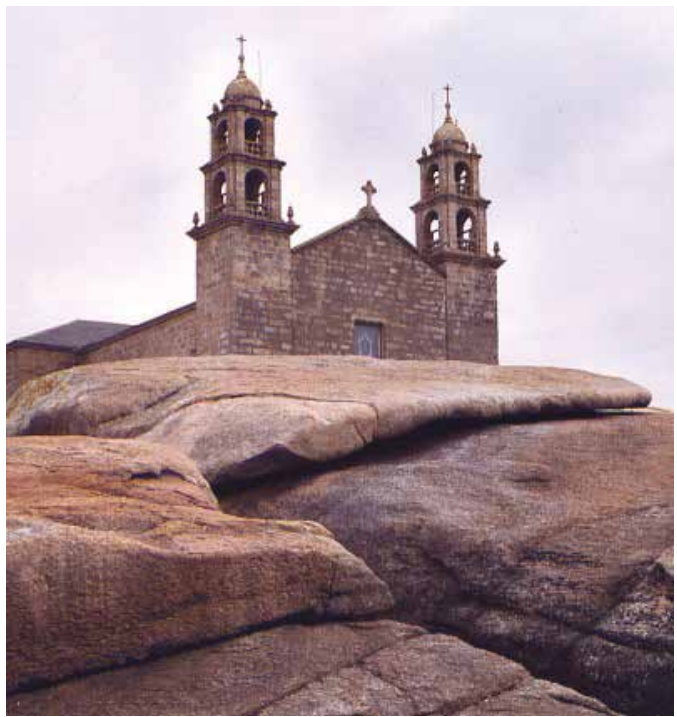

Ill. i 19 - Muxía, Église de Notre-Dame de la Barque (photo Hugo Soria).

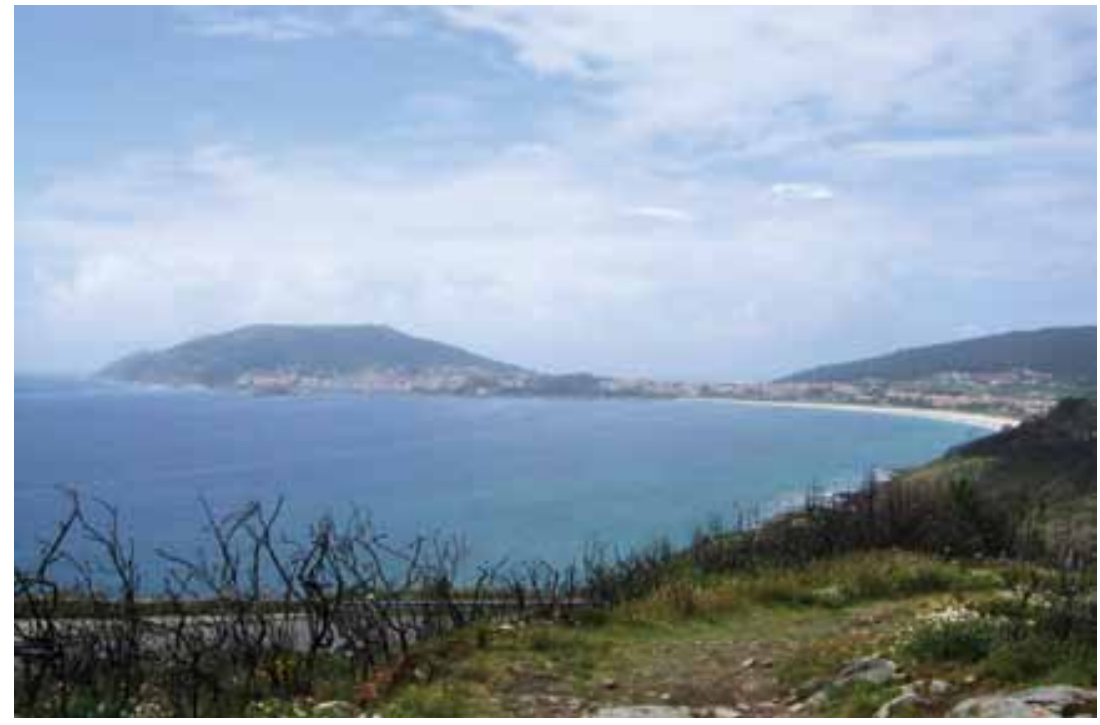

Ill. r 20 - Vue du Cap Finisterre. 